University of Wollongong

Research Online

Faculty of Engineering and Information

Faculty of Engineering and Information

Sciences - Papers: Part B

Sciences

2020

Mechanistic-empirical permanent deformation models: Laboratory testing, modelling and ranking

Ana Ramos

Antonio Gomes

Buddhima Indraratna

University of Wollongong, indra@uow.edu.au

Ngoc Trung Ngo

University of Wollongong, trung@uow.edu.au

Rui Calcada

See next page for additional authors

Follow this and additional works at: https://ro.uow.edu.au/eispapers1

Part of the Engineering Commons, and the Science and Technology Studies Commons

Research Online is the open access institutional repository for the University of Wollongong. For further information contact the UOW Library: research-pubs@uow.edu.au 


\title{
Mechanistic-empirical permanent deformation models: Laboratory testing, modelling and ranking
}

\begin{abstract}
(c) 2020 Elsevier Ltd Geomaterials exhibit elastoplastic behaviour during dynamic and repeated loading conditions. These loads are induced by the passage of a train or vehicle which then generates recoverable (resilient) deformation and/or permanent (plastic) deformation. Modelling this behaviour is still a challenge for geotechnical engineers as it implies the understanding of the complex deformation mechanism and application of advanced constitutive models. This paper reviews on the major causes of permanent deformation and the factors that influence the long-term performance of materials. It will also present the fundamental concepts of permanent deformation as well as the models and approaches used to characterise this behaviour, including: elastoplastic models, shakedown theory and mechanisticempirical permanent deformation models. This paper will focus on the mechanistic-empirical approach and highlight the evolution of the models, and the main similarities and differences between them. $\mathrm{A}$ comparison between several empirical models as well as the materials used to develop the models is also discussed. These materials are compared by considering the reference conditions on the type of material and its physical state. This approach allows for an understanding of which properties can influence the performance of railway subgrade and pavement structures, as well as the main variables used to characterise this particular behaviour. An innovative ranking of geomaterials that relate to the expected permanent deformation and classification (UIC and ASTM) of soil is also discussed because it can be used as an important tool for the design process.

\section{Disciplines}

Engineering | Science and Technology Studies

\section{Publication Details}

Ramos, A., Gomes, A., Indraratna, B., Ngo, N., Calcada, R. \& Costa, P. (2020). Mechanistic-empirical permanent deformation models: Laboratory testing, modelling and ranking. Transportation Geotechnics, 23
\end{abstract}

\section{Authors}

Ana Ramos, Antonio Gomes, Buddhima Indraratna, Ngoc Trung Ngo, Rui Calcada, and Pedro Costa 


\section{Mechanistic-empirical permanent deformation models: laboratory testing,} modelling and ranking

Ana Ramos, University of Minho - School of Engineering, Campus de Azurém, 4800-058, Guimarães, Portugal (id6629@alunos.uminho.pt)

António Gomes Correia, University of Minho - School of Engineering, Campus de Azurém, 4800-058, Guimarães, Portugal (agc@ civil.uminho.pt) - corresponding author

Buddhima Indraratna, University of Wollongong - School of Civil, Mining and Environmental Engineering, Northfields Ave Wollongong, Wollongong, Australia

Trung Ngo, University of Wollongong-School of Civil, Mining and Environmental Engineering, Northfields Ave Wollongong, Wollongong, Australia

Rui Calçada, Faculty of Engineering of University of Porto, Rua Dr. Roberto Frias, 4200-465, Porto Portugal (ruiabc@fe.up.pt)

Pedro Alves Costa, Faculty of Engineering of University of Porto, Rua Dr. Roberto Frias, 4200465, Porto Portugal (pacosta@fe.up.pt)

Abstract:

Geomaterials exhibit elastoplastic behaviour during dynamic and repeated loading conditions. These loads are induced by the passage of a train or vehicle which then generates recoverable (resilient) deformation and/or permanent (plastic) deformation. Modelling this behaviour is still a challenge for geotechnical engineers as it implies the understanding of the complex deformation mechanism and application of advanced constitutive models. This paper reviews on the major causes of permanent deformation and the factors that influence the long-term performance of materials. It will also present the fundamental concepts of permanent deformation as well as the models and approaches used to characterise this behaviour, including: elastoplastic models, shakedown theory and mechanistic-empirical permanent deformation models. This paper will focus on the mechanistic-empirical approach and highlight the evolution of the models, and the main similarities and differences between them. A comparison between several empirical models as well as the materials used to develop the models is also discussed. These materials are compared by considering the reference conditions on the type of material and its physical state. This approach allows for an understanding of which properties can influence the performance of railway subgrade and pavement structures, as well as the main variables used to characterise this particular behaviour. An innovative ranking of geomaterials that relate to the expected permanent deformation and classification (UIC and ASTM) of soil is also discussed because it can be used as an important tool for the design process. 
36 Keywords - mechanistic-empirical permanent deformation models, permanent

37 deformation, laboratory tests, ranking

38

39 Notation list:

40 The most common variables and acronyms are presented:

41 UIC - International Union of Railways

$42 \quad$ ASTM - American Society for Testing and Materials

$43 \quad S S$ - single-stage

$44 \quad M S$ - multi-stage

$45 \quad R L T$ - repeated load tests

$46 \quad M_{r}$ - resilient modulus

$47 \quad N-$ load cycles

$48 \quad \varepsilon_{p}$ - permanent strains

$49 \quad p$ - mean stress

$50 q$-deviatoric stress

$51 q_{f}$-deviatoric stress at failure

$52 \quad p_{a m}$ - amplitude of the mean stress for train loadings

$53 q_{a m}$-amplitude of the deviator stress for train loadings

$54 \quad p_{\text {ini }}$ - mean stress in the initial state of the material

$55 q_{i n i}$-deviator stress in the initial state of the material

$56 \sigma_{1}$ or $\sigma_{d}$ - cyclic vertical stress or cyclic deviator stress

$57 \sigma_{3}$ or $\sigma_{3}-$ Horizontal/confining stress

$58 \sigma_{1} / \sigma_{1: f}$ - failure ratio of the major principal stresses

$59 \sigma_{o c t}$-octahedral normal stress 
$60 \tau_{\text {oct }}$ - octahedral shear stresses

$61 m$ and $s$ - defined by the Mohr-Coulomb yielding criterion $q=s+m p ; m$ is the slope

$62 W_{L}$ - liquid limit

$63 W_{P}-$ plastic limit

$64 \quad I P-$ index plasticity

$65 C u$ - coefficient of uniformity

$66 C c$ - coefficient of gradation 


\section{Introduction}

Pavements and railway structures are designed for a certain lifespan and they usually require reconstruction and/or major maintenance work because the materials may experience fatigue, cracking or be under an excessive amount of cumulative permanent deformation (or rutting in the case of pavements) due to the passage of traffic. Plastic or permanent deformation usually occurs in the geomaterials (base, sub-base or subgrade soils) which are responsible for the surface rutting and that can lead to significant passenger discomfort (Puppala et al., 2009). This is why knowing and understanding the deformation and failure mechanisms of geomaterials under dynamic and cyclic loading are so important when designing and planning the maintenance of pavements and railway structures (Li and Selig, 1996). Indeed, an accurate estimation or prediction of the amount of cumulative settlement will help pavements and /or railway structures avoid a mediocre performance (Barksdale, 1972, Monismith et al., 1975, Puppala et al., 1999). This is why the permanent deformation of geomaterials should be included in the design since otherwise it can lead to higher annual rehabilitation costs (Puppala et al., 1999).

Over the past decades, researchers have been so concerned about permanent deformation and they continually search for the most accurate methods and models that will measure and predict these values (Monismith et al., 1975, Lentz and Baladi, 1980, Ullidtz, 1993, Gidel et al., 2001), among others. To achieve these objectives, laboratory investigations using cyclic triaxial tests, simple and cyclic shear tests, resonant column and hollow cylinder tests, among others have been carried out. These tests were often used to determine shear stress-strain behaviour, resilient modulus $\left(M_{r}\right)$ of subgrade geomaterials considering reversible and irreversible deformation under cyclic loads (Gomes Correia, 2004, Correia, 2008). The reversible (elastic) is usually described by non-linear elastic models, but since permanent deformation is more complex, it depends on the accumulation of $N$ loading cycles.

One of the main objectives of this paper is to review on the main causes of permanent deformation on pavements and railway structures and the factors that can increase this phenomenon. It is noted that while the materials should be able to resist permanent deformation, this resistance will depend on the number of load cycles and stress levels (Lekarp and Dawson, 1998), the thickness of the layer, and the granulometry of the material. This also includes other external factors such as the physical state of the soil, 
which is often difficult to control because it depends on other environmental aspects such as the moisture content, and degree of saturation, etc.

The behaviour of geomaterials under cyclic loads can be characterised by either using complex elastoplastic models (recoverable and permanent deformation are both considered) or by shakedown theory and mechanistic-empirical models (Hornych and Abd, 2004). The elastoplastic models, however, despite their ability to accurately predict permanent deformation (the loading history is considered because the equation is solved based on incremental steps), they are difficult to implement, time consuming, and complex (Ling et al., 2017). Most of these models only consider a low number of load cycles, which is not in accordance with the in situ conditions where the number of loads is up to million cycles. Indeed, these models are very demanding computationally because they require the simulation of repeated load applications in pavements/railway structures. The development of formulations based on cyclic constitutive laws may be expressed through conventional concepts such as the yield condition, hardening and flow rules. The main problem with the numerical implementation is that the increment of permanent deformation per cycle becomes very small quickly, and this leads to problems with the computational accuracy of the results (Abdelkrim et al., 2003). The focus of this work will be on mechanistic-empirical models. These models are based on extensive laboratory testing results, so they can correctly simulate the response of materials; they are easy to implement, and they depend on fewer parameters than conventional elastoplastic models.

In order to select the best testing approach and the most suitable model, it is important to understand the conditions needed for its development such as the properties of the materials tested, degree of compaction, moisture content, etc., as well as the main variables/factors that can influence the response of the material. This paper reviews on the existing methods used to estimate the irreversible deformation of geomaterials, followed by a parametric study that includes comparisons among some selected models on different materials with different classifications (UIC and ASTM), properties, granulometry, and physical states. This comparison allows to estimate the permanent deformation and to rank materials according to the predicted deformation data and soil classification, which is a helpful tool in the design of the pavement and railway structures. It is also noted that this ranking should be interpreted as a reference value because it depends on several properties and soil conditions. 


\section{Causes of permanent deformation}

Permanent deformation occurs in pavements and railway lines due to repeated traffic loading; and if the volume of traffic is high enough it may lead to permanent deformation and/or structural failure. Therefore, it is crucial to identify the main causes of permanent deformation and adopt appropriate measures, even during the design process. Furthermore, transition zones are also important areas due to the possible development of differential settlement due to differences in stiffness between two contiguous structures such as between a ballasted and slab track, or a bridge and a plain track (Figure 1). In fact, the degradation in these zones often accelerates because the differential settlement increases the dynamic effects (Indraratna, 2019).

Another important cause of permanent deformation is related to the complex stress conditions as geomaterials are subjected to vertical, horizontal and shear stresses during the passage of vehicles as well as the effects of moving loads; all of which implies the rotation of principal stresses.

Flexible road pavements often consist of an upper layer of asphalt over unbound granular layers (base, subbase), which have been compacted over a proper soil subgrade. These unbound granular layers provide a structural role, but in some cases when subgrade has an adequate bearing capacity, rutting still occurs in the granular layers causing fatigue cracking in the bituminous layers. This means the bituminous layers and the subgrade will lead to permanent deformation. In rigid pavements, only the subgrade leads to the development of permanent deformation.

Post settlement in railway structures is often caused by the self-weight of the embankment and traffic loading. Permanent deformation includes the settlement of the roadbed beneath the track and the subgrade. Several studies show that the main influencing factors are the level of stress and stress history; in fact the experimental results and field measurements show that the dynamic and cyclic loads from train passage make a significant contribution. It is noted that although both structures are affected by permanent deformation, pavements and railway structures have different dynamic effects on the structure where the dynamic effects are more severe on railway structures.

Permanent deformation has a significant effect on the performance of structures because it leads to an increase in maintenance operations and costs, and reduces ride quality. Despite this is long-term behaviour, it must be predicted during the design stage because although the accumulation is very small during each cycle, it may still lead to 

millions of cycles.

166

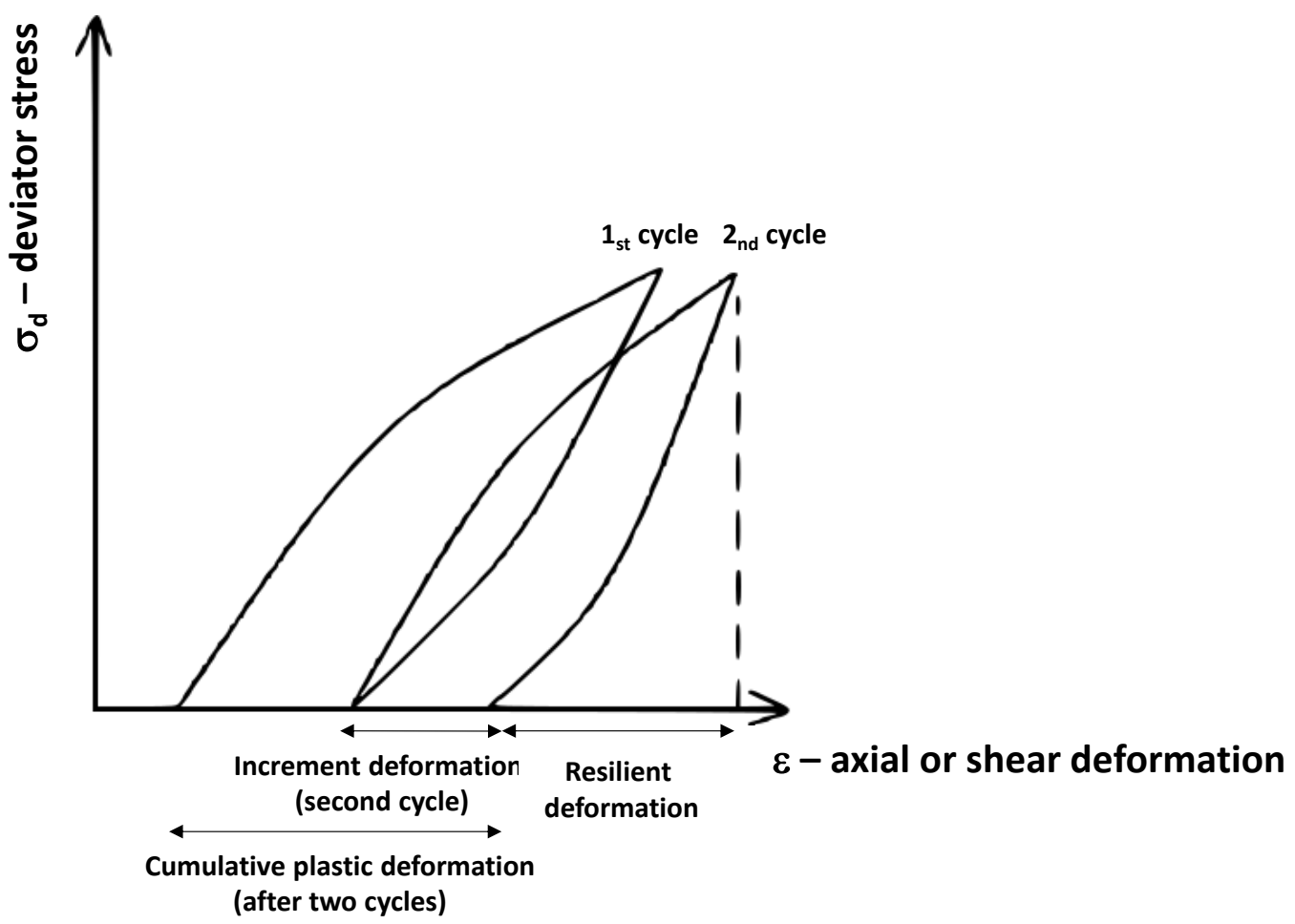

Figure $2 \&$ Figure 3 show that the permanent deformation can be defined and characterised by the accumulation of small increments of deformation during $N$ loading cycles. Several studies show that permanent strains depend directly on the mean and deviator ( $p$ and $q$, respectively), levels of stress (Lekarp et al., 2000). The mean stress is dependent on the sum of the principal stresses while the deviator stress is dependent on the sum of squares of the differences of the principal stresses:

$$
\begin{gathered}
p=\frac{\sigma_{1}+\sigma_{2}+\sigma_{3}}{3} \\
q=\sqrt{\frac{1}{2} \times \sqrt{\left(\sigma_{1}-\sigma_{2}\right)^{2}+\left(\sigma_{2}-\sigma_{3}\right)^{2}+\left(\sigma_{3}-\sigma_{1}\right)^{2}}}
\end{gathered}
$$

\subsection{Factors influencing the permanent deformation}

Permanent deformation is a complex process that directly depends on the number of load cycles $(N)$ and stress levels. While these factors can be divided into load-related factors and material properties, the load factors will include applied stress levels, number of load applications, the strength of material, as well as the loading history and the effect of principal stress rotation. However, other factors can also influence the plastic strain: 
moisture content (degree of saturation), matric suction, fine content, density (degree of compaction), aggregate type, particle size distribution (gradation), and the amount and type of fines (plastic or non-plastic) (Lekarp, 1999, Xiao et al., 2015). Gidel et al. (2001) found that for unbound granular materials, the mineralogical nature of material (including aggregate mineralogy and particle morphology) also influences permanent deformation (Coronado et al., 2011). This factor has important effects on particle shape, the quality of the fines content, and sensitivity to water and surface roughness. However, the stress level and number of load cycles emerge as the most important factors. In fact those models that only consider the value $N$ should not be used to predict permanent deformation because it is too simple and lacks accuracy.

In specific cases of pavements and railway structures, the stress conditions are important because the track foundations are subjected to complex vertical, horizontal and shear stresses. Furthermore, railways and pavements present other complex problems related to the effects that moving loads have on track foundation; for instance, the rotation of principal stresses affects plastic strain. Chan (1990) showed an increase in permanent deformation when the rotation of principal stresses were included. These tests took place in a hollow cylindrical apparatus which allows for simulation in the laboratory and similar conditions to be verified in situ.

\section{Laboratory testing}

There are a number of laboratory tests currently used to evaluate the permanent deformation of geomaterials; they attempt to reproduce in situ stress conditions in pavements and railway structures. The cyclic triaxial test is the most widely used to study of geomaterials subjected to cyclic loads. However, in these tests, the principal stresses are always horizontal or vertical, which may not always correspond to in situ conditions where the materials are subjected to moving loads and rotations of principal stresses. The cyclic vertical stress, designated as $\sigma_{l}$, is applied, and horizontal stress, designated as the confinement stress $-\sigma_{3}$ is also applied. This test begins when deviator stress is applied, and then the applied vertical progressively increases until it reaches an allowable displacement of the apparatus.

Another test used to evaluate permanent deformation is a cyclic torsional test, which also includes a hollow cylinder test. This particular test enables the magnitude and the direction of principal stresses to be controlled. In fact, this test device has been developed 
212 to study permanent deformation and resilient behaviour by considering the rotation of 213 principal stresses, and then applying the laboratory results to in situ conditions. In this 214 case, the specimen is cylindrical and hollow. The main limitations of this test are the 215 dimensions of the sample and the stress path can only be simulated on the symmetrical 216 plane of the track. However, the results show that the permanent deformations are often 217 higher in this test than the convention cyclic triaxial tests due to the simulation of the 218 rotation of principal stresses.

219 Cyclic shear tests can also be used to study the dynamic behaviour of soil. In this test the sample is cylindrical and a horizontal shear force is applied to the bases of the samples. This test can also be used to evaluate stability under seismic events, to quantify the degradation of shear stress in cohesive soils under cyclic loads, and to evaluate the liquefaction parameters of non-cohesive soils under cyclic loading.

There are also other approaches for studying the permanent deformation of geomaterials; for example, while expensive, physical models (1-to-1 prototype model test) can be used to evaluate the performance of geomaterials and the stability of structures subjected to dynamic and repeated loading. These models will provide actual field data to help understand the behaviour of railways and pavements under moving loads, and enable the study of permanent deformation and the stresses induced in soil through proper measurement devices.

While small scale models of railways were introduced in the past (Momoya Y. et al., 2005, Al Shaer A. et al., 2008), several models focusing on the development of permanent deformation of railways under cyclic loadings or moving loads at low speed (Bian et al., 2014) are currently available. However, the field measurements and numerically calibrated results show that increased train speed has a huge influence on the long-term performance of a structure (i.e., higher dynamic stresses and higher permanent deformation). A test facility should be able to simulate the actual speed of a moving train under very large number of load cycles. This means that full-scale models are better because the measured results from a test can be considered directly in the track design and maintenance operations as this approach reduces any uncertainties in the measurements (Bian et al., 2014). 


\section{Modelling approaches}

243 Permanent deformation can be predicted either by numerical simulations using 244 elastoplastic models utilising the shakedown theory or mechanistic-empirical 245 deformation models based on laboratory tests such as cyclic triaxial tests or hollow 246 cylinder apparatus. In addition, the accumulated permanent deformation can be measured

247 by the repeated load triaxial (RLT) tests developed in the laboratory.

248 Mechanistic-empirical permanent deformation models have become much more complex 249 due to the inclusion of other variables, apart from the number of load cycles and stresses. 250 More recently, a study to correlate the resilient modulus $\left(M_{r}\right)$ with the permanent strains $251\left(\varepsilon_{p}\right)$ has been developed. Studies that relate the two parameters $\left(M_{r}\right.$ and $\left.\varepsilon_{p}\right)$ have shown 252 that for subgrade soils, $M_{r}$ has a significant effect on the $\varepsilon_{p}$ or pavement rutting since soils with a higher $M_{r}$ present less permanent strain (Orobio and Zaniewski, 2011, Rahman and Gassman, 2019). However, mixed soils such as silty sand or sandy silts still show significant rutting despite having higher resilient characteristics (Ullidtz, 1993, Puppala et al., 2009).

257 Existing permanent deformation models can be divided into two main categories: rutting models based purely on mechanics, and mechanistic-empirical models. Rutting models are based on elastoplastic theory (Desai, 1980, Desai and Faruque, 1984, Vermeer, 1982, Uzan, 1999, Chazallon, 2000, Chazallon et al., 2002, Chazallon et al., 2006). While they can consider how the stress levels and stress paths can affect permanent deformation, they are very complex and difficult to use because: (i) the increment of permanent strain per cycle is very small; and (ii) the response of the track in each cycle is a challenge for cyclic constitutive models (Chazallon et al., 2006) and numerical implementation (Abdelkrim et al., 2003) due to the extensive calculation time and cumulative errors.

Mechanistic-empirical models often describe a relationship between the number of load cycles and the accumulated permanent deformation. They are very simple to use, the numerical results can be obtained very quickly, and they also predict permanent deformations very well. However, one of the particularities of these models is that their derivation from triaxial tests; which means the conventional and well-known heartshaped stress path (stress rotation) induced by the passage of trains cannot be reproduced in this type of laboratory test. 
Mechanistic-empirical models can be divided into single-stage models and multi-stage models. A single-stage implies that the repetitive load tests are carried out at one stress level in one test; in this instance, multiple specimens are tested at different stress levels. Multi-stage models can test multiple levels of stress in one test on one specimen. This approach enables the effects that the stress level and stress history has on permanent deformation to be considered (Grégoire, 2011).

Shakedown theory

Shakedown theory is another approach used to characterise load-deformation responses of geomaterials. This theory was developed initially based on the behaviour of metals subjected to repeated loading. Werkmeister et al. (2002) further developed to apply for unbound granular materials. The cyclic loads may not lead to instantaneous collapse of the structure since they can induce plastic strain in the material in every load cyclic. Indeed, if the load level is lower than a critical limit, the material will show permanent deformation in the first load cycles. However, after a certain number of $\mathrm{N}$, the material will respond elastically to the subsequent load cycles. This phenomenon is defined as shakedown and this critical limit is called shakedown limit.

Here, the material is divided into three categories (by considering its stress dependency): range $A$, range $B$, and range $C$, as shown in Figure 4 .

Werkmeister (2003) defined the shakedown limits based on the repeated load triaxial test (RLT); these values are also defined by EN13286-7 (2004a):

- Range A: $\left(\varepsilon_{p}{ }^{5000}-\varepsilon_{p}{ }^{3000}\right)<0.045 \times 10^{-3}$

- Range B: $0.045 \times 10^{-3}<\left(\varepsilon_{p}^{5000}-\varepsilon_{p}^{3000}\right)<0.4 \times 10^{-3}$

- Range C: $\left(\varepsilon_{p}^{5000}-\varepsilon_{p}^{3000}\right)>0.4 \times 10^{-3}$

These limits represent the deformation that accumulates between the $3000^{\text {th }}$ and $5000^{\text {th }}$ number of load cycles.

Figure 4 shows that Range $A$ is designated as plastic shakedown where the permanent deformation stabilises after a finite number of load cycles and the material becomes completely resilient. In fact, after a certain point, the cyclic stress does not cause any damage to the structure, which means that the permanent deformation does not increase and the failure does not occur. Range $B$ is designated as the intermediate-range where 
accumulated deformation increases without complete stabilisation. In this case, permanent deformation develops at a very slow rate and is almost linear. Range $B$ occurs when the repeated load cycles overcome plastic shakedown and failure can occur after a large number of load cycles. Range $C$ is defined as incremental collapse because the permanent strain accumulated per cycle increases until the failure occurs. This is caused by shear failure associated with the reorientation and rearrangement of particles, breakage, and the slip and loss of friction between the particles (Sun, 2019). Indeed, failure can occur after a low number of loading cycles. This type of behaviour should never be accepted, unlike materials in the range $A$ or even range $B$. It is reported in recent studies that the shakedown limits were used for the pavement analysis (Qian et al., 2018, Qian et al., 2019b) and in railway structures (Alves Costa et al., 2018).

The shakedown analysis is used to find the shakedown limit of structure under cyclic load. In the case of railway structure, the shakedown is used to predict whether the settlement will keep increasing or reach a stable status. Indeed, there are studies (Werkmeister S, 2005, Brown et al., 2012) about laboratory studies based on different types of materials (granular and soils) where the possibility of shakedown under traffic loads was evaluated (Liu and Wang, 2019). Indeed, the shakedown approach has becoming very popular in pavement engineer, where some progress had been reported (Collins and Boulbibane, 2000, Chazallon et al., 2009a, Chazallon et al., 2009b, Chazallon et al., 2012, Brown et al., 2012). Keep this phenomenon in mind, in order to prevent excessive permanent strain in a certain structure it is important to guarantee that the loading level is below the elastic shakedown limit. Indeed, the assessment of this limit is not easy since demands a significant computational effort mainly in 3D modeling since the loading time-history needs to be considered.

Considering the classical limit analysis theory, two main theorems were formulated to define the limits of shakedown load; the lower bound theorem (conservative solution) and the upper bound theorem (unconservative solution). The application of the lower bound theorem demands an accurate evaluation of the elastic response of the track's foundation due to the traffic. A numerical model can be used to assess the elastic dynamic response of the system (Alves Costa et al., 2018). During the shakedown phenomenon, the structure is subjected to a load that is lower than this limit but higher than the elastic limit and, after the accumulation of permanent deformation in the beginning (finite number of cycles), the material start to show elastic response and after this point, there is no accumulation 
of permanent deformation. This behavior is explained by the total stress field that is given by the sum of the residual stress field with origin in the previous cycles. These conclusions were also obtained by Wang and Yu (2013). The key point of this problem is the assessement of the oad that is compatible with shakedown state. The lower bound theorem states that an elastic perfectly plastic material will shakedown if it is possible to fund a time-independent, self-equilibrated, residual stress field thatcombined with cyclic elastic stresses gives rise to a stress field that no violates the yielding criterion. The shakedown will occur if the following condition is respected (any time and any location):

$$
f\left(\lambda \sigma_{i j}^{e}+\sigma_{i j}^{o}+\sigma_{i j}^{r} \leq 0\right.
$$

where $f$ represents the yielding criterion, $\lambda$ is a load factor of stress field, $\sigma_{i j}^{o}$ is the rest stress state, $\lambda \sigma_{i j}^{e}$ are the elastic stresses induced by the cyclic loads and the residual stress field is given by $\sigma_{i j}^{r}$. The maximum value of $\lambda$, corresponds to the lower value of the shakedown multiplier. The kinematic shakedown theorem states that if any kinematic acceptable mechanism of plastic deformation can be found, the shakedown phenomenon can not occur since the structure will fail due to fatigue (Alves Costa et al., 2018).

Having realised the importance of elastoplastic models and shakedown theory as approaches to predict permanent deformation, the mechanistic-empirical models are also an essential approach and will be presented in the next section. These models are simple and they present an elegant formulation with good results, particularly when compared to the laboratory tests and in situ measurements.

\section{Mechanistic-empirical permanent deformation models}

The mechanistic-empirical model is often derived from laboratory test results such as the triaxial cyclic tests, direct shear tests or large-scale cubical tests. There have been a number of predictive models used to study permanent deformation range from purely empirical to mechanistic and plasticity theory-based models. However, some of these models are only applicable to specific stress states or testing conditions so they have never been evaluated for a wide range of stress states, or types of materials and their physical conditions (Xiao et al., 2015).

It is noted that most of the developed models considered total stress conditions, while ignoring the importance of suction. With regards to the resilient modulus $\left(M_{r}\right)$, there have been several studies about the influence that suction has on the $M_{r}$ even though this 
influence is not widely used in the study of plastic strains (Coronado et al., 2016). Salour and Erlingsson (2016) used a triaxial testing system to control the pore-water pressures of a specimen, so the tests for permanent deformation took place with the control matric suction of the soil samples, and an effective stress approach has been used for modelling.

The mechanistic-empirical permanent deformation models can be divided by considering the materials used in the tests, the approach used during the tests, and the complexity (variables included in the model), as illustrated in Figure 5 and described in the following sections.

\subsection{Materials}

Empirical permanent deformation models can be divided by classifying materials tested as cohesive and granular materials. In the Annex, Table 1 and Table 2 present summarises of the empirical models that characterise the permanent deformation of cohesive materials, fine-grained soils-clays and grained soils-silts, respectively. In addition, Table 3 and Table 4 present key features of empirical models that can be used to obtain the irreversible deformation of granular materials classified as sands and sandy gravels, respectively.

\subsubsection{Cohesive materials}

The plastic strain that accumulates in cohesive materials is a result of the plastic deformation of shear strain, the accumulation of strain due to compaction, consolidation, and associated residual accumulation of excess water pressure. Models for cohesive materials should consider the stress state, the type of soil, and the physical state of the materials, and variables related to the moisture content and dry density. These types of materials are also influenced by environmental conditions and traffic loading, so regardless of the physical state of the material, its influence is considered in most models, and indirectly in the material parameters/constants, as summarised in the Table 1 and Table 2.

The shakedown behaviour of cohesive soils is characterised by the stress-strain loop, and when the load increases, the progressive transition of material from plastic shakedown through plastic creep to incremental collapse can be identified (Yang and Huang, 2007). Yang et al. (2008) indicated that it is not possible to identify the pattern for the cohesive materials shown in Figure 4. Under lower levels of stress, the subgrade (of a pavement or railway structure) will reach an equilibrium strain state after a certain number of load 
cycles. In these cases, plastic strain accumulates very slowly as the number of load cycles increases. As expected, the rutting of pavements or even the failure of subgrade can be prevented by controlling the accumulation of excessive plastic strain by keeping repetitive load levels below the critical stress. Tests results have shown that subgrade soils can easily accumulate excessive plastic strain at high water content, but this will vary depending on the environmental conditions (Yang and Huang, 2007).

\subsubsection{Granular materials}

There have been substantial studies on the use of permanent deformation models for granular materials because of their common use in pavement/railway structures (Indraratna, 2013). The study of granular materials subjected to repetitive loads is fostered by the gradual accumulation of multiple increments of plastic deformation (Figure 3), that could lead to pavement failure due to excessive rutting (Lekarp et al., 2000). In order to justify the use of these materials in pavements some researchers tried to correlate repetitive loading with simple static loading tests (Lentz and Baladi, 1980), but there was no consensus with this approach because granular materials respond differently under static and cyclic loads (Sweere, 1990). Other studies also tried to correlate resilient and plastic deformation through a mathematical expression.

With regard to resilient behaviour, researchers choose a different approaches. Jouve et al. (1987) proposed decomposing axial and horizontal stresses and strains into volumetric and shear components, even though this expression depends on the permanent volumetric and shear strain $(N>100)$ with the mean and deviatoric stresses. Other studies have expressed permanent strain as a function of the number of load cycles (Barksdale, 1972, Sweere, 1990, Wolff and Visser, 1994, Khedr, 1985, Paute et al., 1988, Paute et al., 1994), and some researchers related permanent strain with the stress level and stress ratio (Brown and Hyde, 1975, Barksdale, 1972, Pappin, 1979). Lekarp et al. (2000) found a dependency between permanent strain, and the maximum stress ratio and length of the stress path in $p-q$ space. In fact, applied stress is one of the primary factors that can influence the permanent deformation of aggregates (Xiao et al., 2015). To simulate the correct response of granular materials subjected to cyclic loads (similar to in situ conditions) in a laboratory, variable confining pressure triaxial tests are a practical approach because the effect of horizontal and vertical stresses can be combined. 
429 The behaviour of granular materials under cyclic loads is complex due to the gradual accumulation of permanent strain with the number of load cycles. When a cyclic load is applied to a material there is a gradual accumulation of plastic deformation, a reduction in the number of voids, and an increase in stiffness (Erlingsson and Rahman, 2013, Ba, 2018). As with cohesive soils, the shakedown theory can be used to classify the response of the material in terms of permanent deformation. Furthermore, physical characteristics such as granulometry (poor or well graded) can also influence the response of granular materials, as well as their physical state (Gomes Correia, 2000). However, in most empirical models these variables are not directly considered.

\subsection{Approach}

Based on approach and procedures for a cyclic load test, mechanistic-empirical models can be categorised as either single-stage (SS) or multi-stage (MS) models. Single-stage models mean that repeated load test (RLT) are performed at one stress level in one test, while multi-stage models mean that RLT tests are performed at multiple stress levels in one test on one specimen. This approach is a relatively recent which considers how the stress level and the stress history will affect permanent deformation (Erlingsson and Rahman, 2013). Actually, a multi-stage RLT better represents reality and the real conditions of soils in the field that are subjected to cyclic loads. With the MS approach, the influence of different stress paths with different magnitudes (representing the influence of the effects of stress history) can be analysed. This approach is referred to in EN13286-7 (2004a) and it allows for the application of a certain number of consecutive stress paths to the same specimen, thus reducing the time spent in the laboratory, but it also increases the complexity compared to the single-stage RLT. Gidel et al. (2001) introduced this concept into their work, as did Erlingsson and Rahman (2013) noting that their work was based on the time-hardening concept introduced earlier by Lytton et al. (1993) and Gidel et al. (2001). In this method the permanent deformation formulation is modified (Erlingsson and Rahman, 2013):

$$
\varepsilon_{p}=f_{1}(N) f_{2}\left(p, q, \varepsilon_{r}\right)
$$

456 to

$$
\varepsilon_{p}=f_{1}\left(N-N_{i-1}+N_{i}^{e q}\right) f_{2}\left(p_{i}, q_{i}, \varepsilon_{r i}\right)
$$

457 where, the subscript $i$ refers to the $i$ th stress path and $N_{i}^{e q}$ is determined by considering the following expression: 


$$
N_{i}^{e q}=f_{3}\left(\hat{\varepsilon}_{p i-1}, p_{i}, q_{i}, \varepsilon_{r i}\right)
$$

459

460

461

462

463

464

465

466

467

468

469

470

471

472

473

474

475

476

477

478

479

480

481

482

483

where, $\hat{\varepsilon}_{p i-1}$ is the accumulated permanent strain at the end of the $(i-1)$ th stress path.

Despite the reduction in time, most of the models presented in the bibliography are developed under the single-stage RLT like the Korkiala-Tanttu (2005) model.

\subsection{Complexity}

Empirical permanent deformation models have been changing over time with an increase in their complexity (variables included in the model). Most models establish a relationship between permanent deformation with the number of load cycles and the levels of stress. Some initial studies on resilient and permanent strains only considered the number of load cycles (Barksdale (1972). Despite their simplicity, these models have some historical significance and enable us to understand why stresses are an important factor when determining permanent deformation. In fact, some of these models did consider the stress conditions indirectly in their constants, as presented in Table 5. Some studies showed the importance of the stress state and its influence was considered in the permanent deformation models, as shown in Table 6. It is noted that most of the empirical permanent deformation models the stress levels are defined through the deviatoric $(q)$ and mean $(p)$ stresses.

The most recently well-known models are an improvement on the others. Indeed, the first model only depended on the number of load cycles $(N)$, whereas later models depended on the stress levels and some included the influence of stress indirectly (through their constants); these models are still simple as those developed by Monismith et al. (1975), Sweere (1990) and Huurman (1997).

Most models depend directly on the mean $(p)$ and deviatoric $(q)$ stresses and evaluate the length and slope of the stress path through the relationship established between $q$ and $p$, as does the model developed by Hyde (1974), Lekarp and Dawson (1998) and Rahman and Erlingsson (2015). This model is dependent on the factor $S_{f}$.

$$
\begin{gathered}
\varepsilon_{p}(N)=\alpha N^{b S_{f}} S_{f} \\
S_{f}=\frac{\left(\frac{q}{p_{a}}\right)}{\left(\frac{p}{p_{a}}\right)^{\alpha}}
\end{gathered}
$$

484 Nevertheless, these models have considered the influence of stress dependency by 485 including the stress ratio; for example Huurman (1997) included the effect of the stress 
ratio on one of his model constants by considering the failure ratio of the major principal stresses $\sigma_{1} / \sigma_{1: f}$. This formulation means the deformations are larger when the failure ratio is close to failure. The model define the ratio as the relationship between deviatoric stress and deviatoric stress at failure $\left(q / q_{f}\right)$ because the deviatoric stress is supposed to be the most dominating stress component for permanent strains (Li and Selig, 1996, Chai and Miura, 2002, Korkiala-Tanttu, 2005, Chow et al., 2014, Xiao et al., 2015, Yesufa and Hoffa, 2015, Gu et al., 2016). The model developed by Gidel et al. (2001) and further extended by Chen et al. (2014) is more complex because it depends on the failure criterion by including the strength parameters $m$ and $s$ of the Mohr-Coulomb yielding criterion.

Subsequently, there have been several models including the influence of initial stress indirectly and explicitly (Chai and Miura, 2002, Chen et al., 2014, Ling et al., 2017, Wei et al., 2017) that can explain the apparent decrease of permanent deformation as the initial mean stress increases. Put simply, a higher initial stress leads to a greater distance to the failure criterion which then leads to a lower value of permanent deformation. Some other recent models based on the power-law, $\varepsilon_{p}=A \cdot N^{b}$ include, among other factors, the octahedral normal and shear stresses $\left(\sigma_{o c t}\right.$ and $\left.\tau_{o c t}\right)$ instead of the $p$ and $q$ in the formulation of the model (Puppala et al., 1999, Puppala et al., 2009, Cai et al., 2015). There are more complex models that also include the influence of the physical state of the material, as for example, the model by Xiao et al. (2015), but this model depends on several parameters that can be very difficult to obtain.

To simulate and predict permanent deformation, the most suitable model for each analysis/situation must be chosen, therefore the model must be selected according to the material to be tested and its physical condition. The model must then be evaluated according to its complexity in terms of modelling to the number of variables required by the formulation, and to its efficiency and accuracy with regards to expected results. A simpler model could easily represent in-situ conditions rather than complex models that depend on several variables that may be needed to carry out certain laboratory tests.

\section{A comparison of permanent deformation models - parametric study}

This section attempts to compare different permanent deformation models available for different types of soils considering the model developed by Chen et al. (2014). Whereas this comparison depends on the soil classification, the results go beyond the soil type. 
517 Indeed, while two soils can be integrated into the same classification (UIC or ASTM), the

518 laboratory conditions may differ greatly and therefore lead to different results.

519 It is noted that Chen et al. (2014)'s model considers the stress level (the model includes 520 the amplitude of diagram $p-q$ ), the number of load cycles, the initial stress state, and it 521 quantifies the proximity of the peak stress point $\left(p_{\max }, q_{\max }\right)$ to the yielding criterion. This 522 particular model, therefore, includes several important conditions in its analysis of 523 permanent deformation.

524 For all the experimental data, calibration was performed to find the best fit for the 525 experimental data through the parameters $\varepsilon_{p ; o}, \alpha$ and $B$ (correspond to material 526 properties), presented in the following equation:

$$
\begin{array}{r}
\varepsilon_{1}^{p}(N)=\varepsilon_{1}^{p 0}\left[1-e^{-B N}\right]\left(\frac{\sqrt{p_{a m^{2}}+q_{a m}^{2}}}{p_{a}}\right)^{a} \\
\cdot \frac{1}{m\left(1+\frac{p_{\text {ini }}}{p_{a m}}\right)+\frac{s}{p_{a m}}-\frac{\left(q_{i n i}+q_{a m}\right)}{p_{a m}}}
\end{array}
$$

527 where, $p_{a m}$ and $q_{a m}$ are the amplitude of the mean stress and deviator stress for train 528 loadings, $m$ and $s$ are defined by the yielding criterion $q=s+m p$; and $p_{i n i}$ and $q_{i n i}$ are the mean and deviator stress in the initial state of the material.

530 These selected materials are representative of different types of materials (silt and sand), 531 the percentage of fines, and the granulometry (poor and well graded sands), as depicted 532 in Table 7. The models are calibrated considering the same stress paths for all materials 533 during the calibration process. The stress path described by Chen et al. (2014) is carried 534 out by a cyclic deviator stress of $24 \mathrm{kPa}$ and a constant confining stress of $60 \mathrm{kPa}$. During the cyclic tests the stress ratio $\left(\sigma_{d} / \sigma_{c}\right)$ is constant at 0.4 , which is a representative ratio in

536 the subgrade of a full scale model test. It is noted that other confining stresses from 60 $537 \mathrm{kPa}$ to $210 \mathrm{kPa}$ were also tested. The stress path and the Mohr-Coulomb yielding criterion 538 of each material are shown in Figure 6 showing the stress path applied on the cyclic 539 triaxial test (with a stress ratio equal to 0.4); and the failure envelopes of different 540 materials used in the laboratory tests. The failure envelopes are defined through the Mohr541 Coulomb yielding criterion from the expression $q=s+m p$. 
542 It is seen that the distance between the stress path and the failure envelopes influence the 543 development of permanent deformation. In order to understand which main factors 544 influence cumulative settlement, and compare the long term response of the materials 545 selected, three main models were selected and calibrated as introduced by Huurman 546 (1997), Chen et al. (2014) and Rahman and Erlingsson (2015); these models have been 547 formulated and developed under different conditions in terms of materials and applied 548 stress ratios, as described below.

549 With the Huurman (1997) model, the samples are tested according to their optimum 550 moisture content and with a confining pressure equal to $12 \mathrm{kPa}$, whereas with the Chen 551 et al. model, the specimens are saturated and the boundary is the drainage condition. With 552 the Rahman and Erlingsson (2015) model, the influence that the moisture content has on 553 permanent deformation, and the degree of saturation, is analysed but this analysis only considers the optimum moisture content for each type of soil. Confining pressure, $\sigma_{3}$ is tested as 27.6, 41.4 and $55.2 \mathrm{kPa}$, and cyclic deviator stress varies according to the stress path. Thus, the development of these models includes laboratory conditions such as soils under different state conditions and different stress conditions.

558 Whereas Huurman (1997) considers seven poorly graded sands and one well-graded sand 559 (designated as crusher), only C. Bruynweg and Crusher corresponds to the poor and well560 graded sands are analysed (Table 8). In addition, the C. Bruynweg was selected as the stress ratio is similar to the one carried out by Chen et al. (2014). The remaining sands were tested for stress conditions close to failure $\left(\sigma_{1} / \sigma_{1 ; f}\right.$ close or equal to one), which is outside the representative stress conditions of this study. In this work, the parameters of Huurman's model are adjusted so that the parameters $\varepsilon_{p 0}, a$ and $B$ can be obtained; this adjustment took place through the formulation lscurvefit in Matlab.

566 In Rahman and Erlingsson (2015), two silty sands are analyzed and compared with the 567 parameters of Chen's model. The study also shows a correlation between the $\varepsilon_{p 0}$ and $\alpha$ 568 parameters and the moisture content. In the work developed by Chen et al. (2014), a coarse sand and a silt are analysed and then the properties of these materials are divided according to their granulometry (Table 8), their state conditions (Table 9), and their failure parameters (Table 10).

572 It is important to first consider Huurman (1997) work in order to understand the influence 573 that granulometry (well and poorly graded soil) has on permanent deformation. The 20 
analysis utilises the following stress ratios: $0.695,0.803,0.911$. Figure 7 shows that wellgraded sand has larger permanent deformation values for each stress ratio, which means that granulometry has an important influence on permanent deformation, as expected.

Table 11 presents the calibrations of the models for each selected soil where a regression analysis was performed. It is seen that there is some correlation (exponential and polynomial) between the three constant variables $-\varepsilon_{p 0}, \alpha$ and $\beta$ (superior to 0.7 ) - but correlation between the constant variables and UIC classification (QS1, QS2, and QS3) is only residual.

The comparison between the permanent deformation curves presented in Figure 8. It is seen that the results of silty sand and coarse sand (43\% and $27 \%$ of fines) are very close, whereas the well and poorly-graded sand and silt are at opposite sides (the highest and smallest value of permanent deformation). This result is related to QS3-SW sand because a lower value was expected in comparison to QS2-SP. Another important fact is related to the influence of the stress ratio; in this instance, the permanent deformation results are not $100 \%$ aligned with those presented in Figure 6 because higher permanent deformation is expected when the stress path is close to the yielding criterion that depends on the values $s$ and $m$ of the Mohr-Coulomb yielding criterion. This means that in addition to the strength properties, the soil physical properties (represented by the constants in the model) are also important in permanent deformation.

\section{Ranking the materials}

The materials and calibration process described in the previous section enable the results to be interpreted and the materials can be ranked according to their resistance to permanent deformation (Coronado et al., 2011). This information can then be used to predict permanent deformation during the design process. The ranking process provides reference values according to the type of material as well as the moisture content close to optimum conditions. In reality, Figure 9 is a re-interpretation of Figure 8. This innovative procedure enables the expected values of permanent deformation to be compared according to the type of material through the UIC and ASTM soil classification; this ranking also includes different types of soils (clays and sands) and different granulometry. Figure 9 shows that the materials classified as CL-ML have a higher permanent deformation than the sands (SM, SP, and SW), while the sands with fines have a higher deformation than the SP and SW sands; therefore this parameter influences the permanent 
deformation and ranking of the geomaterials. During the design process the long-term behaviour of the materials can be estimated, even though the permanent deformation will be influenced by their state conditions such as the moisture content; therefore the influence of this parameter in this analysis must be traduced.

Among other factors, moisture content also influences permanent deformation. Puppala et al. (2009) developed a model which depends on the octahedral normal and shear stresses (Table 1 and Table 3). Different materials, clay, silt, and sand with moisture contents ranging from dry of optimum, optimum and wet of optimum were tested. Three different confining pressures were applied to the clay and silt (0,21 and $42 \mathrm{kPa})$, and confining pressures of 21, 48 and $97 \mathrm{kPa}$ were applied to the sand. The deviatoric stress was determined by considering a percentage of the maximum deviatoric stress of each soil sample obtained in the unconsolidated undrained triaxial tests, so the deviatoric stress varies from $0.2 \sigma_{\mathrm{d}, \mathrm{f}}, 0.4 \sigma_{\mathrm{d}, \mathrm{f}}$ and $0.6 \sigma_{\mathrm{d}, \mathrm{f}}$.

To evaluate the influence that the moisture content has on permanent deformation, the results from Puppala et al. (2009) are used, but this analysis only focuses on the behaviour of clay (QS1 - CL) because it was not contemplated in previous studies. This exercise shows how important this parameter is, and the consequences in terms of permanent deformation when the moisture content moves away from the optimum conditions. Material properties are presented in Table 12, and as with the previous models and materials, the curve of permanent deformation has been adjusted to obtain the model parameters.

Figure 10 shows that the differences between dry, optimum and wet materials in terms of permanent deformation after 30000 cycles is significant; the optimum material is 4-8 times higher than the dry material, and the wet material is 1-2 times higher than the optimum conditions. Therefore, when the moisture content is far away from optimum conditions, the variations of permanent deformation in the clays are substantial. In dry conditions, this value decreases significantly and in wet conditions, it increases which means that maximum permanent deformation occurs when the moisture content is beyond optimum (wet) due to an increase in the residual accumulation of excess water pressure.

\section{Conclusions}

The ability to determine the permanent deformation of geomaterials is very important when modelling and evaluating the performance of pavements and railway structures; it 22 
is also a key factor when estimating future maintenance operations and the respective costs. This review paper has aimed to frame the main reasons why permanent deformation models were developed, particularly in pavements and railway structures. However, some issues related to traffic-induced permanent deformation weren't evaluated in this paper, such as the estimation of the dynamic stresses and strategies to simulate the effect of rotation of principal stresses. Indeed, these topics will be evaluated in further works related with the numerical modelling of a railway structure, including the influence of the train's speed in the stress results and permanent deformation. It is expected that the train's speed will increase the stress amplitude (the stress path is close to the yielding criterion) and also the permanent strain.

648

In this paper, it was found that permanent deformation can be evaluated and predicted through laboratory tests, and most mechanistic-empirical models were based on cyclic triaxial tests.

Main concepts of permanent deformation and the laboratory tests used to predict them were reviewed, the approaches used to simulate permanent deformation such as elastoplastic models, shakedown theory, and mechanistic-empirical models were discussed. The definition of the shakedown is a very popular approaches nowadays since allows to prevent plastic deformation that can be critical after some years of exploration. This method became popular in pavement engineering with inclusion of 3D modelling and generalization of the method for non-isotropic materials. However, the application of the shakedown analysis in railway engineering is limited. The shakedown approach however, demands the accurate assessment of the response of the track foundation due to railway traffic, which also demands powerful numerical modelling. It was found that the mechanistic-empirical model reduced the time needed for calculations, it has simple and elegant formulations, good predictive results, and is easy to implement in a numerical scheme. These mechanistic-empirical models were defined and categorised according to the materials tested, the approach used in the laboratory (single-stage or multi-stage), the complexity of the formulation, and the variables included in the mathematical expression. It was concluded that the permanent deformation models should also include the influence of the main stress variables ( $p$ and $q$ ), the initial state of the materials, the number of load cycles, and the distance to the rupture line; moreover the constant parameters should also reflect the influence of factors such as the state conditions of the material. However, those 
complex mechanistic-empirical models that depend on several variables can also imply a need for tests other than a standard triaxial cyclic test, in order to obtain more parameters. The mechanistic-empirical models summarised in the Annex were divided according to the type of material (clay, silt, sand and gravel) to better understand the model's formulation and the condition of the material tested in terms of its granulometry $(\mathrm{Cu}$ and $C c)$ and plasticity properties $\left(\mathrm{W}_{\mathrm{L}}, \mathrm{W}_{\mathrm{P}}\right.$, and IP). The Tables also include some observations regarding the laboratory tests and classification of the material (UIC and ASTM). This information (including the classification) can be very helpful when modelling substructure and predicting its performance.

Considering the available mechanistic-empirical models as well as understanding the main variables and factors that can affect the long-term response of geomaterials, it is important to evaluate the robustness of the models and their sensitivity. Thus, some models and materials were selected to perform a parametric study. The choice depends on the data available for each material and the diversity and variability of the geomaterials (type of soils) in terms of its granulometry, percentage of fines, moisture content, and plasticity properties, etc.

In the comparison analysis: silt, silty sand, and sand were divided according to properties such as the percentage of fines (27\% and $43 \%$ ) and granulometry (poor and well-graded materials). Selected experimental results found in the literature were then adapted to Chen's model. The calibration process was performed to compare the long-term response of these geomaterials, after which they were defined and ranked based on the results of permanent deformation. This ranking tool can be used during the design process for estimating the permanent deformation of a certain type of material after $N$ loading cycles, while considering the ASTM and UIC classification. As expected, the comparison showed that the values of permanent deformation decreased according to the UIC classification, so well-classified materials showed a reduction in permanent deformation. Furthermore, the deformation behaviour of these materials also depended on their granulometry, the percentage of fines, and the moisture content. Based on the proposed ranking, a brief analysis has been carried out to understand and quantify the influence of the moisture content. The results showed that for a material classified as QS1 (CL), designated as clay, the moisture content exerts a significant influence on permanent deformation. 


\section{Acknowledgments}

702 This work was partially carried out under the framework of In2Track, a research project 703 of Shift2Rail. It was also supported by FCT - "Fundação para a Ciência e a Tecnologia" $704-\mathrm{PD} / \mathrm{BD} / 127814 / 2016$. 


\section{References}

Abdelkrim, M., Bonnet, G. \& Buhan, P. D. 2003. A computational procedure for predicting the long term residual settlement of a platform induced by repeated traffic loading. Computers and Geotechnics, 30, 463-476.

Al Shaer A., Duhamel D., Sab K., Foret G. \& L., S. 2008. Experimental settlement and dynamic behavior of a portion of ballasted railway track under high speed trains. Journal of Sound and Vibration, 316, 213-233.

Alves Costa, P., Lopes, P. \& Silva Cardoso, A. 2018. Soil shakedown analysis of slab railway tracks: Numerical approach and parametric study. Transportation Geotechnics, 16, 85-96.

Ara, I. \& Division, E. C. 2004. Guide for mechanistic-empirical design of new and rehabilitated pavement structures (Final report, NCHRP project 1-37A). Washington, DC: Transportation Research Board of the National Academies.

$\mathrm{Ba}, \mathrm{M}$. 2018. Correlation between resilient modulus and permanent deformation during a large scale model experiment of unbound base course. Lecture Notes in Civil Engineering.

Barksdale, R. D. Laboratory evaluation of rutting in base course materials. Proc. 3rd Int. Conf on the Structural Design of Asphalt Pavements, 1972 London.

Bian, X., Jiang, H., Cheng, C., Chen, Y., Chen, R. \& Jiang, J. 2014. Full-scale model testing on a ballastless high-speed railway under simulated train moving loads. Soil Dynamics and Earthquake Engineering, 66, 368-84.

Brown, S., Yu, H., Juspi, H. \& J, W. 2012. Validation experiments for lower-bound shakedown theory applied to layered pavement systems. Géotechnique 62, 923-932.

Brown, S. F. \& Hyde, A. F. L. Significance of cycling confining stress in repeated-load triaxial testing of granular material. Transp. Res. Rec, 1975 Washington D.C.: Transportation Research Board, 49-58.

Cai, Y., Sun, Q., Guo, L., Juang, C. H. \& Wang, J. 2015. Permanent deformation characteristics of saturated sand under cyclic loading. Canadian Geotechnical Journal, 52, 795-807.

Chai, J.-C. \& Miura, N. 2002. Traffic-load-induced permanent deformation of road on soft soil. Journal of Geotechnical and Geoenvironmental Engineering, 128, 907-916.

Chan, A. H. 1990. Permanent deformation resistance of granular layers in pavements. PhD thesis, University of Nottingham, England.

Chazallon, C. 2000. An elastoplastic model with kinematic hardening for unbound aggregates in roads. UNBAR 5 Conference. Nottingham.

Chazallon, C., Allou, F., Hornych, P. \& Mouhoubi, S. 2009a. Finite elements modelling of the longterm behaviour of a full-scale flexible pavement with the shakedown theory. Int. J. Numer. Anal. Meth. Geomech, 33, 45-70.

Chazallon, C., Habiballah, T. \& Hornych, P. 2002. Elastoplasticity framework for incremental or simplified methods for unbound granular materials for roads. BCRA workshop on modelling of flexible pavements. Lisbon.

Chazallon, C., Hornych, P. \& Mouhoubi, S. 2006. Elastoplastic model for the long-term behavior modeling of unbound granular materials in flexible pavements. Int. J. Geomech., 279289.

Chazallon, C., Koval, G., Hornych, P., Allou, F. \& Mouhoubi, S. 2009b. Modelling of rutting of two flexible pavements with the shakedown theory and the finite element method. 36, 798809.

Chazallon, C., Koval, G. \& Mouhoubi, S. 2012. A two-mechanism elastoplastic model for shakedown of unboundgranular materials and DEM simulations. Int. J. Numer. Anal. Meth. Geomech, 36, 1847-1868.

Chen, R., Chena, J., Zhaob, X., Bian, X. \& Chen, Y. 2014. Cumulative settlement of track subgrade in high-speed railway under varying water levels. International Journal of Rail Transportation, 2, 205-220. 
Chow, L. C., Mishra, D. \& Tutumluer, E. 2014. Framework for development of an improved unbound aggregate base rutting model for mechanistic-empirical pavement design. Transportation Research Record: Journal of the Transportation Research Board, 2401, $11-21$.

Collins, I. \& Boulbibane, M. 2000. Geomechanical analysis of unbound pavements based on shakedown theory J Geotech Geoenviron Eng 126, 50-9.

Coronado, O., Caicedo, B., Taibi, S., Correia, A. G. \& Fleureau, J.-M. 2011. A macro geomechanical approach to rank non-standard unbound granular materials for pavements. Engineering Geology, 119, 64-73.

Coronado, O., Caicedo, B., Taibi, S., Correia, A. G., Souli, H. \& Fleureau, J.-M. 2016. Effect of water content on the resilient behavior of non standard unbound granular materials. Transportation Geotechnics, 7, 29-39.

Correia, A. G. Innovations in design and construction of granular pavements and railways. Advances in Transportation Geotechnics - Proceedings of the 1st International Conference on Transportation Geotechnics, 2008. 3-13.

Desai, C. S. 1980. A general basis for yield, failure and potential function in plasticity. Int. J. Numer. Anal. Methods Geomech., 4, 361-375.

Desai, C. S. \& Faruque, M. O. 1984. Constitutive model for geologic materials. J. Eng. Mech. Div., 1391-1408.

En13286-7 2004a. Unbound and hydraulically bound mixtures. Part 7: Cyclic load triaxial test for unbound mixtures Brussels.: CEN-European Committee for Standardization.

Erlingsson, S. \& Rahman, M. S. 2013. Evaluation of permanent deformation characteristics of unbound granular materials by means of multistage repeated-load triaxial tests. Transport Research Record: Journal of the Transportation Research Board, 2369, 11-19.

Erlingsson, S., Rahman, S. \& Salour, F. 2017. Characteristic of unbound granular materials and subgrades based on multi stage RLT testing. Transportation Geotechnics, 13, $28-42$.

Gidel, G., Hornych, P., Chauvin, J.-J., Breysse, D. \& Denis, A. 2001. A new approach for investigating the permanent deformation behaviour of unbound granular material using the repeated load triaxial apparatus. Bulletin des Laboratoires des Pont et Chaussées, $233,5-21$.

Gomes Correia, A. 2000. Influence of compaction conditions on resilient and permanent deformations of aggregates mixtures of granite. Gomes Correia and Quibel (Editors), Compaction of soils and granular materials. Paris: Presse Nationale des Ports et des Chaussées.

Gomes Correia, A. 2004. Evaluation of mechanical properties of unbound granular materials for pavements and rail tracks. Gomes Correia and Loizos (Editors), Geotechnics in Pavement and Railway Design and Construction., MillPress.

Grégoire, C. C., António G; De Bel, R; Dethy, B. 2011. Mechanical behavior of natural and recycled granular materials for roads. Journal of Testing and Evaluation 39.

Gu, F., Zhang, Y., Droddy, C. V., Luo, R. \& Lytton, R. L. 2016. Development of a new mechanistic empirical rutting model for unbound granular material. J. Mater. Civ, 28.

Guo, L. 2013. Experimental study on the static and cyclic behavior of saturated soft clay under complex stress path. PhD Thesis, Zhenjiang Univ., Hangzhou, China (in Chinese).

Hornych, P. \& Abd, A. E. 2004. Selection and evaluation of models for prediction of permanent deformations of unbound granular materials in road pavements. Work Package 5, Performance-based specifications. SAMARIS.

Huurman, M. 1997. Permanent deformation in concrete block pavement. PhD Thesis, Delft University of Technology, Netherlands.

Hyde, A. F. L. 1974. Repeated load triaxial testing of soils. PhD thesis, University of Nottingham, Nottingham. 
Indraratna, B., Babar Sajjad, M., Ngo, T., Gomes Correia, A. And Kelly, R. 2019. Improved Performance of Ballasted Tracks at Transition Zones: A Review of Experimental and Modelling Approaches. Transportation Geotechnics, 21.

Indraratna, B., Ngo, N.T. And Rujikiatkamjorn, C. 2013. Deformation of coal fouled ballast stabilized with geogrid under cyclic load. Journal of Geotechnical and Geoenvironmental Engineering, 139, 1275-1289.

Jouve, P., Martinez, J., Paute, J. L. \& Ragneau, E. Rational model for the flexible pavements deformations. Proceedings of the 6th International Conference on Structural Design of Asphalt pavements, 1987 Ann Arbor. 50-64.

Khedr, S. 1985. Deformation characteristics of granular base course in flexible pavement. Transportation Research Record, 1043, 131-138.

Korkiala-Tanttu, L. A new material model for permanent deformations in pavements. Proc. of the Seventh Conference on Bearing Capacity of Roads and Airfields, 2005 Trondheim, Norway. 10.

Lekarp, F. 1999. Resilient and permanent deformation behavior of unbound aggregates under repeated loading. PhD Thesis, The Royal Institute of Technology, KTH, Stockholm, Sweden.

Lekarp, F. \& Dawson, A. 1998. Modelling permanent deformation behaviour of unbound granular materials. Construction and Building Materials, 12, 9-18.

Lekarp, F., Isacsson, U. \& Dawson, A. 2000. Permanent strain response of unbound aggregates. Journal of Transportation Engineering, 126, 76-83.

Lentz, R. W. \& Baladi, G. Y. Simplified procedure to characterize permanent strain in sand subjected to cyclic loading. Proceedings Int. Symposium on Soils Under Cyclic and Transient Loading, 1980 Swansea. 89-95.

Li, D. \& Selig, E. T. 1996. Cumulative plastic deformation for fine-grained subgrade soils. Journal of Geotechnical and Geoenvironmental Engineering, 122, 1006-1013.

Ling, X., Li, P., Zhang, F., Zhao, Y., Li, Y. \& An, L. 2017. Permanent deformation characteristics of coarse grained subgrade soils under train-induced repeated load. Advances in Materials Science and Engineering, 201715.

Liu, S. \& Wang, J. Application of shakedown theory in track substructure design. Proceedings of the Institution of Civil Engineers - Ground Improvement, 2019.

Lytton, R. L., Uzan, J., Fernando, E. G., Roque, R., Hiltunen, D. \& Stoffels, S. M. 1993. Development and validation of performance prediction models and specifications for asphalt binders and paving mixes. Report SHRPA-357: TRB, National Research Council, Washington, D.C.

Momoya Y., Sekine E. \& F., T. 2005. Deformation characteristics of railway roadbed and subgrade under moving-wheel load. Soils Found., 45, 99-118.

Monismith, C. L., Ogawa, N. \& Freeme, C. R. 1975. Permanent deformation characteristics of subgrade soils due to repeated loading. Transportation Research Record, 537, 1-17.

Orobio, A. \& Zaniewski, J. P. 2011. Sampling-based sensitivity analysis of the mechanisticempirical pavement design guide applied to material inputs. J. of Trans. Res. Rec., 2226, 95-93.

Pappin, J. W. 1979. Characteristics of a granular material for pavement analysis. PhD Thesis, University de Nottingham.

Paute, J., Hornych, P. \& Benaben, J. 1988. Comportement mecanique des graves non traitees. Bull Liasion Laboratories Ponts Chaussées, 156, 21-36.

Paute, J. L., Hornych, P. \& Benaben, J. P. 1994. Comportement mécanique des graves non traitées. Bulletin de Liaison des Laboratoires des Ponts et Chaussées, 190, 27-38.

Puppala, A. J., Mohammad, L. N. \& Allen, A. 1999. Permanent deformation characterization of subgrade soils from RLT test. Journal of Materials in Civil Engineering, 11, 274-282. 
Puppala, A. J., Saride, S. \& Chomtid, S. 2009. Experimental and modeling studies of permanent strains of subgrade soils. Journal of Geotechnical and Geoenvironmental Engineering, $135,1379-1389$.

Qian, J., Lin, H., Gu, X. \& Xue, J. 2018. Dynamic shakedown limits for flexible pavement with cross-anisotropic materials. Road Materials and Pavement Design, 1-21.

Qian, J., Shiyuan Li, Xiaoqiang Gu \& Zhang, J. 2019a. A unified model for estimating the permanent deformation of sand under a large number of cyclic loads. Ocean Engineering 181 293-302.

Qian, J., Wang, Y., Wang, J. \& Huang, M. 2019b. The influence of traffic moving speed on shakedown limits of flexible pavements. International Journal of Pavement Engineering, 20, 233-244.

Rahman, M. M. \& Gassman, S. L. 2019. Permanent deformation characteristics of coarse grained subgrade soils using repeated load triaxial tests. Geo-Congress 2019. Philadelphia, Pennsylvania.

Rahman, M. S. \& Erlingsson, S. 2015. A model for predicting permanent deformation of unbound granular materials. Road Materials and Pavement Design, 16, 653-673.

Salour, F. \& Erlingsson, S. Characterization of permanent deformation of silty sand subgrades from multistage RLT tests. The 3rd International Conference on Transportation Geotechnics (ICTG 2016), 2016 Guimarães, Portugal. 300-307.

Sun, Q., Indraratna, B. And Ngo, N.T. 2019. Effect of increase in load and frequency on the resilience of railway ballast. Géotechnique, $69,833-840$.

Sweere, G. T. H. 1990. Unbound granular bases for roads. PhD Thesis, Delft University of Technology, Netherlands.

Tseng, K. H. \& Lytton, R. L. Prediction of permanent deformation in flexible pavement materials. In: SCHRAUDERS, H. G. \& MAREK, C. R., eds. Implication of aggregates in design, construction, and performance of flexible pavements, 1989a Philadelphia. PA: American Society for Testing and Materials, 154-172.

Tseng, K. H. \& Lytton, R. L. 1989b. Prediction of permanent deformation in flexible pavements materials, implication of aggregates in the design, construction, and performance of flexible pavements. ASTM STP 1016, ASTM, West Conshohocken, PA, 154-172.

Ullidtz, P. 1993. Mathematical model of pavement performance under moving wheel load. J. of Trans. Res. Rec., Washington, D.C., 1384, 94-99.

Uzan, J. 1999. Permanent deformation of a granular base material. Transp. Res. Rec., 1673, 8994.

Vermeer, P. A. A five-constant model unifying well-established concepts. Proc., Int. Workshop on Constitutive Relations for Soils, 1982. A.A. Balkema, Rotterdam, Netherlands, 175197.

Wang, J. \& Yu, H. 2013. Residual stresses and shakedown in cohesive-frictional half-space under moving surface loads. Geomech Geoeng 8, 1-14.

Wei, X., Wang, G. \& Wu, R. 2017. Prediction of traffic loading-induced settlement of lowembankment road on soft subsoil. International Journal of Geomechanics, 17.

Werkmeister, S. 2003. Permanent deformation behavior of unbound granular materials. PhD Thesis, University of Technology, Dresden, Germany.

Werkmeister S, D. a. a. W. F. 2005. Permanent deformation behaviour of granular materials. . Road Materials and Pavement Design, 6, 31-51.

Werkmeister, S., Numrich, R. \& Wellner, F. The development of a permanent deformation design model for unbound granular materials with the shakedown-concept. Proc. of the 6th International Conference on the Bearing Capacity of Roads and Airfields, 2002 Lisbon, Portugal. 1081-1096.

Wolff, H. \& Visser, A. T. Incorporating elasto-plasticity in granular layer pavement design. Proceedings of the Institution of Civil Engineers-Transport, 1994. 259-272. 
Xiao, J., Juang, C., Wei, K. \& Xu, S. 2014. Effects of principal stress rotation on the cumulative deformation of normally consolidated soft clay under subway traffic loading. Journal of Geotechnical and Geoenvironmental Engineering, 140.

Xiao, Y., Tutumluer, E. \& Mishra, D. 2015. Performance evaluation of unbound aggregate permanent deformation models for different aggregate physical properties. Transport Research Record: Journal of the Transportation Research Board, 2525, 20-30.

Yang, S.-R. \& Huang, W.-H. 2007. Permanent deformation and critical stress of cohesive soil under repeated loading. Transport Research Record: Journal of the Transportation Research Board, 2016, 23-30.

Yang, S.-R., Huang, W.-H. \& Liao, C.-C. 2008. Correlation between resilient modulus and plastic deformation for cohesive subgrade soil under repeated loading. Transport Research Record, Transportation Research Board, 2053.

Yesufa, G. Y. \& Hoffa, I. 2015. Finite element modelling for prediction of permanent strains in fine-grained subgrade soils. Road Materials and Pavement Design, 16, 392-404. 


\section{Annex}

An extensive list of the permanent deformation based on laboratory tests are presented in this Annex.

Although these tables are constructed in a uniform manner, especially the nomenclature of the variables and the parameters and characteristics of the materials, the authors still maintained the original symbols and nomenclature describe in the original paper.

Some models were developed using certain SI units, and where possible these units are described in the column "variables and empirical constants".

The permanent deformation is an adimensioal parameter that can also be designated as permanent strain and its numenclature varies, as mentiond above. The permamen strain is defined as change in the length of the material and expressed as a function of the length being changed, The plastic/permanent deformation is defined as not recoverable. The materials that are part of the pavements and railway structures accumulate some amout of permanent deformation due to the traffic cyclic load. The stress parameters (induced by the cyclic loads) are one of the main inputs of these models. The inclusion of this parameter in the permanent deformation model varies as well as the numenclature. Indeed, there are models dependent on the $p$ and $q$ (mean and deviatoric) stresses or on the octahdral stresses, for example.

In the permanent deformation tables the deviator stress is represented by $q_{d}, q$ or $\sigma_{d}$, the variable for the atmospheric pressure/reference stress is represented by $\sigma_{a t m}, p_{0}, p_{a}$ or $p_{r e f}$, while the equation models were developed under different conditions, so permanent deformation is represented in the following tables by the nomenclatures: $\varepsilon_{p}, \varepsilon_{p l, N}, \varepsilon_{z}^{p}, \varepsilon_{q ; r}$ (axial residual strain), $\varepsilon_{1}^{p}, \varepsilon_{p}(\mathrm{~N}), \varepsilon_{1}^{p}(N)$. The constants of the models used to fit the model to the available data, are represented by different letters and symbols which are defined as material parameters, model constants, and model parameters and soil parameters, as listed in the permanent deformation tables. 
Table 1. Summaries of permanent deformation models for fine-grained soils - clays

\begin{tabular}{|c|c|c|c|c|c|c|}
\hline UIC & $\begin{array}{c}\text { ASTM } \\
\text { classification }\end{array}$ & $\begin{array}{c}\text { Author's } \\
\text { model }\end{array}$ & $\begin{array}{l}\text { Equation } \\
\text { Model }\end{array}$ & $\begin{array}{c}\text { Variables and } \\
\text { Empirical Constants }\end{array}$ & $\begin{array}{c}\text { Parameters and } \\
\text { characteristics }\end{array}$ & Observations \\
\hline- & - & $\begin{array}{l}\text { Monismith et } \\
\text { al. (1975) }\end{array}$ & $\varepsilon^{p}=A N^{b}$ & $\begin{array}{l}\varepsilon_{\mathrm{p}} \text { is the plastic } \\
\text { deformation }(\%) ; \\
N \text { is the number of load } \\
\text { cycles; } \\
A \text { and } b \text { are two } \\
\text { parameters that } \\
\text { represent the influence } \\
\text { of other factors. }\end{array}$ & - & $\begin{array}{l}\text { This model has a limited } \\
\text { practical used since there are } \\
\text { other factors, besides } N \text {, that } \\
\text { can influence the permanent } \\
\text { deformation; } \\
b \text { is an independent } \\
\text { parameter on the deviatoric } \\
\text { stress; } \\
\text { The coefficient } A \\
\text { corresponds to the plastic } \\
\text { deformation after the first } \\
\text { cyclic load. }\end{array}$ \\
\hline - & - & $\begin{array}{c}\text { Chai and } \\
\text { Miura (2002) }\end{array}$ & $\begin{aligned} \varepsilon^{p}=a\left(\frac{q_{d}}{q_{f}}\right)^{m} & (1 \\
& \left.+\frac{q_{s}}{q_{f}}\right)^{n} N^{b}\end{aligned}$ & $\begin{array}{l}q_{s} \text { is the initial static } \\
\text { deviatoric stress; } \\
n=\text { constant. }\end{array}$ & - & $\begin{array}{l}\text { This model includes the } \\
\text { effects of initial static stress, } \\
\text { the magnitude and number of } \\
\text { applied loads associated to } \\
\text { the passage of the vehicle, } \\
\text { and the properties of the } \\
\text { subsoil in terms of } \\
\text { compression and strength. }\end{array}$ \\
\hline - & - & $\begin{array}{l}\text { Yesufa and } \\
\text { Hoffa } \\
(2015)^{*}\end{array}$ & $\varepsilon_{p 1, N}=N^{m\left(1-\left(\sigma_{d} / q_{s}\right)\right.} \varepsilon_{p 1,0}$ & $\begin{array}{l}\varepsilon_{p 1, N} \text { is the axial } \\
\text { permanent deformation } \\
\text { for the cyclic load } N \text {; } \\
\varepsilon_{p 1,0} \text { is the } \\
\text { cummulative axial } \\
\text { permanent deformation } \\
\text { after the first cyclic } \\
\text { load; }\end{array}$ & - & $\begin{array}{l}\text { The parameters of these } \\
\text { materials were found through } \\
\text { triaxial tests: the static } \\
\text { deviatoric stress comes from } \\
\text { the difference between the } \\
\text { axial and confining stress in } \\
\text { failure; } \\
\varepsilon_{p 1,0} \text { is from the equivalent } \\
\text { static load in the first cyclic }\end{array}$ \\
\hline
\end{tabular}




\begin{tabular}{|c|c|c|c|c|c|c|}
\hline & & & & $\begin{array}{l}\sigma_{d} \text { is the deviatoric } \\
\text { stress induced by the } \\
\text { passage of the vehicle; } \\
q_{s} \text { is the static stress } \\
\text { measured on the soil; } \\
m \text { is a constant } \\
\text { determined to fit the } \\
\text { laboratory test's } \\
\text { results. }\end{array}$ & & $\begin{array}{l}\text { load (based on the plasticity } \\
\text { theory). }\end{array}$ \\
\hline - & - & $\begin{array}{l}\text { Cai et al. } \\
(2015)\end{array}$ & $\begin{array}{l}\varepsilon_{z}^{p} \\
=\alpha_{1} N^{\alpha_{2}}\left(\frac{\sigma_{o c t}}{\sigma_{a t m}}\right)^{\alpha_{3}}\left(\frac{\tau_{o c t}}{\sigma_{a t m}}\right)^{\alpha} \\
\left(\sqrt{1+4 \eta^{2}}\right)^{\alpha_{5}}\end{array}$ & $\begin{array}{l}\alpha_{1}, \alpha_{2}, \alpha_{3}, \alpha_{4} \text { and } \alpha_{5} \text { are } \\
\text { constants of the model } \\
\text { and determined through } \\
\text { laboratory tests; } \\
\sigma_{o c t} \text { and } \tau_{o c t} \text { are the } \\
\text { normal and shear } \\
\text { octahedral stresses, } \\
\text { respectively; } \\
\sigma_{a t m} \text { is the reference } \\
\text { stress; } \\
\eta \text { is the cyclic torsional } \\
\text { stress ratio. }\end{array}$ & . & $\begin{array}{l}\text { This model is based on a } \\
\text { series of tests using the } \\
\text { hollow cylinder apparatus. } \\
\text { The characteristics of the } \\
\text { permanent deformation of a } \\
\text { sand were then studied in } \\
\text { drained conditions by } \\
\text { considering different } \\
\text { confining stress levels, ratio } \\
\text { of the cyclic vertical stress } \\
\text { and ratio of the cyclic } \\
\text { torsional stress; } \\
\text { The model was developed to } \\
\text { include the rotation of } \\
\text { principal stresses. }\end{array}$ \\
\hline $\begin{array}{c}\text { QS0 } \\
\text { High plasticity }\end{array}$ & $\begin{array}{c}\mathrm{CH} \\
\text { Fat clay }\end{array}$ & $\begin{array}{l}\text { Li and Selig } \\
\quad(1996)\end{array}$ & $\varepsilon^{p}=a\left(\frac{q_{d}}{q_{f}}\right)^{m} N^{b}$ & $\begin{array}{l}q_{d} \text { is the traffic-load- } \\
\text { induced dynamic } \\
\text { deviator stress; } \\
q_{f} \text { is the static failure } \\
\text { deviator stress of soil; }\end{array}$ & $\begin{array}{l}a=0.64 \\
b=0.10 \\
m=1.7\end{array}$ & \\
\hline
\end{tabular}




\begin{tabular}{|c|c|c|c|c|c|c|}
\hline & & & & $\begin{array}{l}a, b \text { and } m \text { are soil } \\
\text { parameters and are } \\
\text { related to the plasticity } \\
\text { index of the subsoil. }\end{array}$ & & \\
\hline $\begin{array}{c}\text { QS0 } \\
\text { Heavy clay }\end{array}$ & $\begin{array}{c}\mathrm{CH} \\
\text { Fat Clay }\end{array}$ & $\begin{array}{c}\text { Puppala et al. } \\
\text { (1999) }\end{array}$ & $\begin{array}{l}\log \varepsilon^{p} \\
=\log A \\
+\alpha \log N+\beta \log \left(\frac{\sigma_{o c t}}{\sigma_{a t m}}\right)\end{array}$ & $\begin{array}{l}A, \beta \text { and } \alpha \text { are soil } \\
\text { parameters; } \\
\sigma_{o c t} \text { and } \tau_{o c t} \text { are the } \\
\text { octahedral normal and } \\
\text { shear stresses, } \\
\text { respectively. }\end{array}$ & $\begin{array}{l}\mathrm{W}_{\mathrm{L}}=93 \% ; \\
\mathrm{W}_{\mathrm{P}}=29 \% ; \\
\mathrm{I}_{\mathrm{P}}=64 \% \text { (high } \\
\text { plasticity); } \\
\text { Sand content }=0 \% ; \\
\text { Silt content }=5 \% ; \\
\text { Clay content }=95 \% \text {. }\end{array}$ & $\begin{array}{l}\text { The model was tested based } \\
\text { on triaxial tests; } \\
\text { During this study, materials } \\
\text { such as well graded sand, } \\
\text { silty clay and clay were } \\
\text { considered. }\end{array}$ \\
\hline $\begin{array}{c}\text { QS0 } \\
\mathrm{W}_{\mathrm{L}}=60 \% \\
\text { High plasticity }\end{array}$ & $\begin{array}{l}\text { (without } \\
\text { enough data } \\
\text { to carry out } \\
\text { the ASTM } \\
\text { classification } \\
\text { ) }\end{array}$ & $\begin{array}{l}\text { Wei et al. } \\
\text { (2017) - } \\
\text { based on } \\
\text { Guo (2013) - } \\
\text { (Wenzhou } \\
\text { structural } \\
\text { clay) }\end{array}$ & $\begin{array}{l}\varepsilon_{q, r}=A N^{b} \\
A=\varepsilon_{q, r}=\alpha K_{q} K_{\mathrm{T}} K_{\alpha} K_{\sigma}\end{array}$ & $\begin{array}{l}\varepsilon_{q, r} \text { is the axial residual } \\
\text { strain; } \\
A \text { is the residual strain } \\
\text { generated in the first } \\
\text { cycle; } \\
b \text { is a material } \\
\text { parameter determining } \\
\text { the cumulating rate of } \\
\text { the residual strain with } \\
\text { loading cycles and is } \\
\text { equal to the gradient of } \\
\text { the residual strain curve } \\
\text { in the ln } \varepsilon_{q, r}-\text { ln } \mathrm{N} \\
\text { coordinate; } \\
K_{q} \text { and } K_{\mathrm{T}} \text { are } \\
\text { functions to reflect the } \\
\text { effect of wheel load- } \\
\text { induced stress; } \\
K_{\alpha} \text { and } K_{\sigma} \text { are } \\
\text { functions to reflect the } \\
\text { effect of initial static }\end{array}$ & $\begin{array}{l}\mathrm{W}_{\mathrm{n}}=60-62 \% ; \\
\mathrm{G}_{\mathrm{s}}=2.71 ; \mathrm{S}_{\mathrm{t}}=5.9 ; \\
\mathrm{M}(\text { critical stress } \\
\text { ratio })=1.31 .\end{array}$ & $\begin{array}{l}\text { This model is based on the } \\
\text { power function developed by } \\
\text { Monismith et al. (1975); } \\
\text { The parameter } A \text { depends on } \\
\text { the initial stress state and the } \\
\text { imposed dynamic stress on } \\
\text { non-remoulded Wenzhou } \\
\text { clay samples (Guo, 2013). } \\
\text { The samples were collected } \\
\text { from a depth of 6-7 m; } \\
\text { The parameters are based on } \\
\text { the work by Xiao et al. } \\
\text { (2014) who carried out a } \\
\text { series of tests based on the } \\
\text { hollow cylinder apparatus. }\end{array}$ \\
\hline
\end{tabular}




\begin{tabular}{|c|c|c|c|c|c|c|}
\hline & & & & $\begin{array}{l}\text { stress state and } \\
\text { dynamic stress } \\
\text { combinations. }\end{array}$ & & \\
\hline $\begin{array}{c}\text { QS1 } \\
\text { (low plasticity) }\end{array}$ & $\begin{array}{c}\mathrm{CL} \\
\text { Lean clay }\end{array}$ & Hyde (1974) & $\varepsilon_{1}^{p}=a \frac{q}{\sigma_{3}}$ & $\begin{array}{l}a \text { is a constant; } \\
\sigma_{3} \text { is the confining } \\
\text { stress; } \\
q \text { is deviator stress. }\end{array}$ & $\begin{array}{l}\mathrm{W}_{\mathrm{L}}=32 \% \\
\mathrm{~W}_{\mathrm{P}}=18 \% \\
\mathrm{I}_{\mathrm{P}}=14 \% \\
\mathrm{G}_{\mathrm{s}}=2.74\end{array}$ & $\begin{array}{l}\text { The tests included a constant } \\
\text { and variable confining stress; } \\
\text { During the analysis, the } \\
\text { behaviour of the marl was } \\
\text { studied; } \\
\text { The author states that these } \\
\text { results would be the same if } \\
\text { medium confining stress was } \\
\text { applied. }\end{array}$ \\
\hline $\begin{array}{l}\text { QS1 } \\
\text { Low to } \\
\text { medium } \\
\text { plasticity }\end{array}$ & $\begin{array}{c}\text { CL } \\
\text { Lean clay }\end{array}$ & $\begin{array}{l}\text { Li and Selig } \\
\text { (1996) }\end{array}$ & $\varepsilon^{p}=a\left(\frac{q_{d}}{q_{f}}\right)^{m} N^{b}$ & $\begin{array}{l}q_{d} \text { is the traffic-load- } \\
\text { induced dynamic } \\
\text { deviator stress; } \\
q_{f} \text { is the static failure } \\
\text { deviator stress of soil; } \\
a, b \text { and } m \text { are soil } \\
\text { parameters and are } \\
\text { related to the plasticity } \\
\text { index of the subsoil. }\end{array}$ & $\begin{array}{l}a=0.84 \\
b=0.13 \\
m=2.0\end{array}$ & \\
\hline $\begin{array}{c}\text { QS1 } \\
\text { Silty clay }\end{array}$ & $\begin{array}{c}\mathrm{CL} \\
\text { Lean clay }\end{array}$ & $\begin{array}{l}\text { Puppala et al. } \\
\text { (1999) }\end{array}$ & $\begin{array}{l}\log \varepsilon^{p} \\
=\log A \\
+\alpha \log N+\beta \log \left(\frac{\sigma_{o c t}}{\sigma_{a t m}}\right)\end{array}$ & $\begin{array}{l}A, \beta \text { and } \alpha \text { are soil } \\
\text { parameters; } \\
\sigma_{o c t} \text { and } \tau_{o c t} \text { are the } \\
\text { octahedral normal and } \\
\text { shear stresses, } \\
\text { respectively. }\end{array}$ & $\begin{array}{l}\mathrm{W}_{\mathrm{L}}=44 \% ; \\
\mathrm{W}_{\mathrm{P}}=15 \% ; \\
\mathrm{I}_{\mathrm{P}}=29 \% \text { (medium } \\
\text { plasticity); } \\
\text { Sand } \\
\text { content }=10 \% ; \\
\text { Silt content }=70 \% ; \\
\text { Clay content }=20 \% .\end{array}$ & $\begin{array}{l}\text { The model was tested based } \\
\text { on triaxial tests; } \\
\text { During this study, well- } \\
\text { graded sand, silty clay and } \\
\text { clay were tested. }\end{array}$ \\
\hline $\begin{array}{c}\text { QS1 } \\
\text { Silty clay }\end{array}$ & $\begin{array}{c}\mathrm{CL} \\
\text { Lean clay }\end{array}$ & $\begin{array}{l}\text { Puppala et al. } \\
\qquad(2009)\end{array}$ & $\begin{array}{l}\varepsilon^{p} \\
=\alpha_{1} N^{\alpha_{2}}\left(\frac{\sigma_{o c t}}{P_{\text {ref }}}\right)^{\alpha_{3}}\left(\frac{\tau_{\text {oct }}}{P_{\text {ref }}}\right)\end{array}$ & $\begin{array}{l}\alpha_{1}, \alpha_{2}, \alpha_{3} \text { and } \alpha_{4} \text { are the } \\
\text { model constants }\end{array}$ & $\begin{array}{l}\mathrm{W}_{\mathrm{L}}=28.19 \% \\
\mathrm{I}_{\mathrm{P}}=12.55 \% \text { (low } \\
\text { plasticity); } \\
\mathrm{G}_{\mathrm{s}}=2.63\end{array}$ & $\begin{array}{l}\text { The model is based on } \\
10,000 \text { cycles; } \\
\text { It includes the effects of } \\
\text { mean and shear stresses; }\end{array}$ \\
\hline
\end{tabular}




\begin{tabular}{|c|c|c|c|c|c|c|}
\hline & & & & $\begin{array}{l}\text { determined from } \\
\text { laboratory tests; } \\
\sigma_{o c t} \text { and } \tau_{o c t} \text { are the } \\
\text { octahedral normal and } \\
\text { shear stresses, } \\
\text { respectively; } \\
P_{\text {ref }} \text { is the reference } \\
\text { stress. }\end{array}$ & $\begin{array}{l}\text { Passing \#200 } \\
=80 \% ; \\
\text { Maximum dry unit } \\
\text { weight }=17.10 \\
\mathrm{kN} / \mathrm{m}^{3} ; \\
\mathrm{W}_{\text {opt }}=17.11 \% ; \\
\mathrm{c}=60 \mathrm{kPa} ; \\
\phi=18^{\circ} .\end{array}$ & $\begin{array}{l}\text { The model was tested based } \\
\text { on the cyclic triaxial tests; } \\
\text { The permanent deformation } \\
\text { of clay, silt and sand were } \\
\text { measured from samples of } \\
\text { compacted soil with different } \\
\text { water content. }\end{array}$ \\
\hline $\begin{array}{l}\text { QS1 } \\
\text { Silty clayed } \\
\text { sand }\end{array}$ & $\begin{array}{c}\text { CL } \\
\text { Lean Clay }\end{array}$ & $\begin{array}{l}\text { Puppala et al. } \\
\text { (2009) }\end{array}$ & $=\alpha_{1} N^{\alpha_{2}}\left(\frac{\sigma_{o c t}}{P_{\text {ref }}}\right)^{\alpha_{3}}\left(\frac{\tau_{\text {oct }}}{P_{\text {ref }}}\right)^{\alpha}$ & $\begin{array}{l}\alpha_{1}, \alpha_{2}, \alpha_{3} \text { and } \alpha_{4} \text { are the } \\
\text { model constants } \\
\text { determined from } \\
\text { laboratory tests; } \\
\sigma_{o c t} \text { and } \tau_{o c t} \text { are the } \\
\text { octahedral normal and } \\
\text { shear stresses, } \\
\text { respectively; } \\
P_{\text {ref }} \text { is the reference } \\
\text { stress. }\end{array}$ & $\begin{array}{l}\mathrm{W}_{\mathrm{L}}=16.70 \% ; \\
\mathrm{I}_{\mathrm{P}}=7.50 \% \text { (low } \\
\text { plasticity); } \\
\mathrm{G}_{\mathrm{s}}=2.70 ; \\
\text { Passing } \\
\# 200=38 \% ; \\
\text { Maximum dry unit } \\
\text { weight }=16.9 \\
\mathrm{kN} / \mathrm{m}^{3} ; \\
\mathrm{W}_{\text {opt }}=19.3 \% ; \\
\mathrm{c}=103 \mathrm{kPa} ; \\
\phi=35^{\circ} \text {. }\end{array}$ & $\begin{array}{l}\text { The model is based on } \\
10,000 \text { cycles; } \\
\text { It includes the effects of the } \\
\text { mean and shear stresses; } \\
\text { The model was tested based } \\
\text { on the cyclic triaxial tests; } \\
\text { The permanent deformations } \\
\text { of clay, silt and sand were } \\
\text { measured from samples of c } \\
\text { soil compacted with different } \\
\text { water contents. }\end{array}$ \\
\hline QS1 & $\begin{array}{c}\text { CL } \\
\text { Lean clay }\end{array}$ & $\begin{array}{c}\text { Wei et al. } \\
\text { (2017) - } \\
\text { based on } \\
\text { Xiao et al. } \\
\text { (2014) - } \\
\text { Clay } \\
\text { (Shanghai } \\
\text { structural soft } \\
\text { clay) }\end{array}$ & $\begin{array}{l}\varepsilon_{q, r}=A N^{b} \\
A=\varepsilon_{q, r}=\alpha K_{q} K_{\mathrm{T}} K_{\alpha} K_{\sigma}\end{array}$ & $\begin{array}{l}\varepsilon_{q, r} \text { is the axial residual } \\
\text { strain; } \\
A \text { is the residual strain } \\
\text { generated in the first } \\
\text { cycle; } \\
b \text { is a material } \\
\text { parameter determining } \\
\text { the cumulating rate of } \\
\text { the residual strain with } \\
\text { loading cycles and is } \\
\text { equal to the gradient of } \\
\text { the residual strain curve }\end{array}$ & $\begin{array}{l}\mathrm{I}_{\mathrm{P}}=21.8 \% ; \\
\mathrm{I}_{\mathrm{L}}=1.35 \text { (medium } \\
\text { plasticity); } \\
\mathrm{G}_{\mathrm{s}}=2.74 ; \\
\mathrm{W}_{\mathrm{n}}=51.8 \% ; \\
\mathrm{e}_{0}=1.402 ; \\
\mathrm{M}(\text { critical stress } \\
\text { ratio })=1.28 .\end{array}$ & $\begin{array}{l}\text { The model is based on the } \\
\text { power function developed by } \\
\text { Monismith et al. (1975); } \\
\text { The parameter } A \text { depends on } \\
\text { the initial stress state and the } \\
\text { imposed dynamic stress on } \\
\text { samples of non-remoulded } \\
\text { Wenzhou clay (Guo, 2013). } \\
\text { The samples were collected } \\
\text { from a depth of } 6-7 \text { m; } \\
\text { The parameters were } \\
\text { determined based on the }\end{array}$ \\
\hline
\end{tabular}




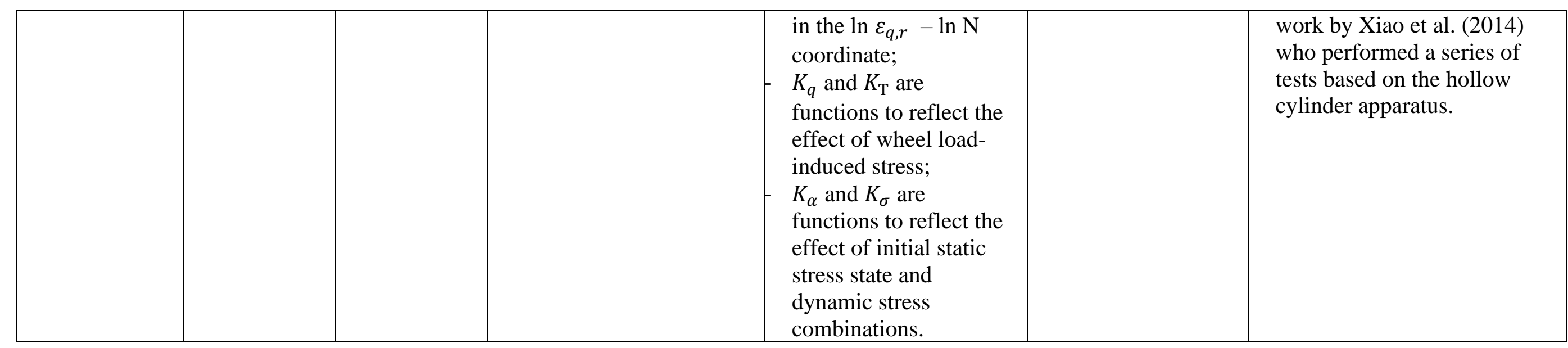


Table 2. Summarises of permanent deformation models for fine-grained soils - silts

\begin{tabular}{|c|c|c|c|c|c|c|}
\hline UIC & $\begin{array}{c}\text { ASTM } \\
\text { classification }\end{array}$ & $\begin{array}{l}\text { Author's } \\
\text { model }\end{array}$ & $\begin{array}{l}\text { Equation } \\
\text { model }\end{array}$ & $\begin{array}{c}\text { Variables and } \\
\text { Empirical Constants }\end{array}$ & $\begin{array}{l}\text { Parameters and } \\
\text { characteristics }\end{array}$ & Observations \\
\hline $\begin{array}{l}\text { QS1 } \\
\text { Low to } \\
\text { medium } \\
\text { plasticity }\end{array}$ & $\begin{array}{l}\text { ML } \\
\text { Silt }\end{array}$ & $\begin{array}{l}\text { Li and Selig } \\
\text { (1996) }\end{array}$ & $\varepsilon^{p}=a\left(\frac{q_{d}}{q_{f}}\right)^{m} N^{b}$ & $\begin{array}{l}q_{d} \text { is the traffic-load- } \\
\text { induced dynamic } \\
\text { deviator stress; } \\
q_{f} \text { is the static failure } \\
\text { deviator stress of soil; } \\
a, b \text { and } m \text { are soil } \\
\text { parameters and are } \\
\text { related to the plasticity } \\
\text { index of the subsoil. }\end{array}$ & $\begin{array}{l}\mathrm{a}=1.2 \\
\mathrm{~b}=0.18 \\
\mathrm{~m}=2.4\end{array}$ & \\
\hline QS1 & $\begin{array}{l}\text { ML-CL } \\
\text { Silt - Lean } \\
\quad \text { clay }\end{array}$ & $\begin{array}{l}\text { Chen et al. } \\
\text { (2014) }\end{array}$ & $\begin{array}{l}\varepsilon_{1}^{p}(N) \\
=\varepsilon_{1}^{p 0}[1 \\
\left.-e^{-B N}\right]\left(\frac{\sqrt{p_{a m^{2}}+q_{a m^{2}}}}{p_{a}}\right) \\
\frac{1}{m\left(1+\frac{p_{\text {ini }}}{p_{a m}}\right)+\frac{s}{p_{a m}}-\underline{\left(q_{\text {ini }}\right.}}\end{array}$ & $\begin{array}{l}\varepsilon_{1}^{p}(N) \text { is the strain } \\
\text { settlement; } \\
\varepsilon_{1}^{p 0}, B, a, s \text { and } m \text { are } \\
\text { material parameters; } \\
p_{a}=100 \mathrm{kPa} \text {; } \\
p_{\text {ini }} \text { and } q_{\text {ini }} \text { are the } \\
\text { mean and deviator } \\
\text { stress in the initial state } \\
\text { of the layer; } \\
p_{a m} \text { and } q_{a m} \text { are the } \\
\text { amplitude of mean } \\
\text { stress and deviator } \\
\text { stress for train } \\
\text { loadings, respectively; } \\
s \text { is the intersection of } \\
\text { the Mohr-Coulomb } \\
\text { yielding criterion in the } \\
q \text { axle in the } p-q \text { space; }\end{array}$ & $\begin{array}{l}\mathrm{W}_{\mathrm{L}}=35 \% \\
\mathrm{~W}_{\mathrm{P}}=24 \% \\
\mathrm{I}_{\mathrm{P}}=11 \% \text { (low to } \\
\text { medium plasticity); } \\
\mathrm{G}_{\mathrm{s}}=2.67 ; \\
\mathrm{C}_{\mathrm{u}}=2.51 ; \mathrm{C}_{\mathrm{c}}=1.32 ; \\
\text { Maximum dry } \\
\text { density }=15.89 \\
\mathrm{kN} / \mathrm{m}^{3} ; \\
\mathrm{Hydraulic} \\
\text { permeability }= \\
5.3 \times 10^{-7} \mathrm{~m} / \mathrm{s} ; \\
\mathrm{c}^{\prime}=11.7 \mathrm{kPa} ; \\
\phi^{\prime}=16.4^{\mathrm{o}} .\end{array}$ & $\begin{array}{l}\text { The model is based on } \\
\text { Gidel's model (Gidel et } \\
\text { al., 2001); } \\
\text { This model takes into } \\
\text { account the direct } \\
\text { influence of the initial } \\
\text { stress state. }\end{array}$ \\
\hline
\end{tabular}




\begin{tabular}{|l|l|l|l|l|l|}
\hline & & & $\begin{array}{l}m \text { is the slope of the } \\
\text { yielding criterion. }\end{array}$ & \\
\hline
\end{tabular}


Table 3. Permanent deformation models for granular soils (sands)

\begin{tabular}{|c|c|c|c|c|c|c|}
\hline UIC & $\begin{array}{c}\text { ASTM } \\
\text { classification }\end{array}$ & $\begin{array}{c}\text { Author's } \\
\text { model }\end{array}$ & $\begin{array}{c}\text { Equation } \\
\text { model }\end{array}$ & $\begin{array}{c}\text { Variables and } \\
\text { Empirical Constants } \\
\end{array}$ & $\begin{array}{c}\text { Parameters and } \\
\text { characteristics }\end{array}$ & Observations \\
\hline - & - & $\begin{array}{c}\text { MEPDG } \\
\text { model } \\
\text { (Ara and } \\
\text { Division, } \\
2004 \text { ) }\end{array}$ & $\varepsilon_{p}=\beta_{s}\left(\frac{\varepsilon_{0}}{\varepsilon_{r}}\right) e^{-(\rho / N)^{\beta}} \varepsilon_{v}$ & $\begin{array}{l}\beta_{s} \text { is the global } \\
\text { calibration coefficient; } \\
\varepsilon_{r} \text { is the resilient strain } \\
\text { imposed in the } \\
\text { laboratory test; } \\
\varepsilon_{v} \text { is the average } \\
\text { vertical resilient strain } \\
\text { (in the base layer of the } \\
\text { flexible pavements, for } \\
\text { example). }\end{array}$ & 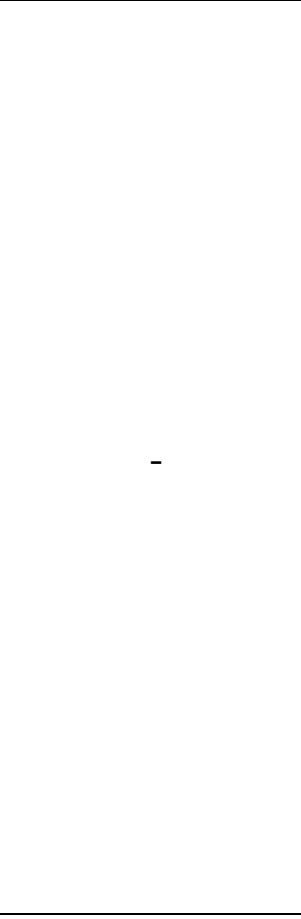 & $\begin{array}{l}\text { This model considers the } \\
\text { effect of the stress on } \\
\text { permanent deformation by } \\
\text { linearly projecting the } \\
\text { plastic deformation } \\
\text { obtained from the } \\
\text { laboratory tests through } \\
\text { vertical strains. This } \\
\text { projection is an } \\
\text { assumption without any } \\
\text { experimental or } \\
\text { mechanical justification; it } \\
\text { is therefore inaccurate due } \\
\text { to the nonlinear effect that } \\
\text { stress has on the } \\
\text { permanent deformation of } \\
\text { unbound granular } \\
\text { materials - UGM (Gu et } \\
\text { al., 2016). }\end{array}$ \\
\hline - & - & $\begin{array}{c}\text { Korkiala- } \\
\text { Tanttu (2005) }\end{array}$ & $\varepsilon_{p}(N)=C N^{b} \frac{R}{A-R}$ & $\begin{array}{l}C \text { is a parameter } \\
\text { dependent on the stress } \\
\text { and also compaction } \\
\text { degree and water } \\
\text { content; } \\
b \text { is a parameter } \\
\text { dependent on the stress } \\
\text { level, ratio of failure, } \\
\text { compaction degree and } \\
\text { water content; }\end{array}$ & - & $\begin{array}{l}\text { This model is based on the } \\
\text { Sweere's model (Sweere, } \\
\text { 1990). } \\
\text { It uses the deviatoric } \\
\text { stress ratio to capture the } \\
\text { nonlinear effect of the } \\
\text { stress state. However, } \\
\text { plastic deformation is } \\
\text { infinity when the load } \\
\text { cycles go to infinity, so }\end{array}$ \\
\hline
\end{tabular}




\begin{tabular}{|c|c|c|c|c|c|c|}
\hline & & & & $\begin{array}{l}A \text { corresponds to the } \\
\text { maximum value of the } \\
\text { ratio (the author } \\
\text { suggests a value close } \\
\text { to } 1.05 \text { ); } \\
R=\frac{q}{q_{f}}, q \text { is the } \\
\text { deviatoric stress and } q f \\
\text { corresponds to the } \\
\text { failure deviatoric } \\
\text { stress; }\end{array}$ & & $\begin{array}{l}\text { the model cannot } \\
\text { demonstrate the hardening } \\
\text { and softening behavior of } \\
\text { UGM. }\end{array}$ \\
\hline - & - & $\begin{array}{l}\text { Chow et al. } \\
\text { (2014) }\end{array}$ & ${ }_{\varepsilon}^{p}=A N^{B} \sigma_{d}^{C}\left(\frac{\tau_{f}}{\tau_{\max }}\right)^{D}$ & $\begin{array}{l}\sigma_{d} \text { is the deviatoric } \\
\text { shear stress; } \\
\tau_{f} \text { is the shear stress; } \\
\tau_{\max } \text { is the shear } \\
\text { strength; } \\
A, B, C \text { and } D \text { are the } \\
\text { regression coefficients. }\end{array}$ & - & $\begin{array}{l}\text { The model includes the } \\
\text { power functions of } \\
\text { deviatoric shear stress and } \\
\text { the shear strength ratio; } \\
\text { The author developed } 16 \\
\text { types of materials with one } \\
\text { confining pressure (=34.5 } \\
\mathrm{kPa} \text { ) and three deviatoric } \\
\text { stresses. The RLT tests } \\
\text { show that this model has } \\
\text { higher } \mathrm{R}^{2} \text { values but when } \\
\text { the number of load cycles } \\
(N) \text { goes to infinity, the } \\
\text { accumulated plastic } \\
\text { deformation also goes to } \\
\text { infinity at one confining } \\
\text { pressure. Moreover, the } \\
\text { deviatoric shear stress term } \\
\text { affects the shear ratio in the } \\
\text { model and both parameters } \\
\text { represent the softening } \\
\text { behavior of the material }\end{array}$ \\
\hline
\end{tabular}




\begin{tabular}{|c|c|c|c|c|c|c|}
\hline & & & & & & $\begin{array}{l}\text { without including the } \\
\text { hardening phenomenon. }\end{array}$ \\
\hline - & - & $\begin{array}{l}\text { Xiao et al. } \\
\quad(2015)\end{array}$ & $\begin{aligned} \varepsilon_{p}=a\left(\frac{\theta}{p_{0}}\right)^{b} & \left(\frac{\tau_{f}}{\tau_{\text {máx }}}\right)^{c} N^{d} \\
& \cdot E X P[e \\
& \cdot\left(S-S_{o p t}\right) \\
& +f \cdot w P I \\
& +g \cdot w P I \\
& \cdot \frac{\tau_{f}}{\tau_{\max }}+h \\
& \cdot\left(S-S_{o p t}\right) \\
& \left.\cdot \frac{\theta}{p_{0}}\right]\end{aligned}$ & $\begin{array}{l}\theta \text { is the sum of the } \\
\text { principal stresses; } \\
\tau_{f} \tau_{\text {máx }} \text { is the ratio } \\
\text { related to the shear } \\
\text { stress; } \\
S \text { corresponds to the } \\
\text { saturation level; } \\
S_{\text {opt }} \text { corresponds to the } \\
\text { optimum saturation } \\
\text { level; } \\
w P I \text { corresponds to a } \\
\text { weighted plasticity } \\
\text { index; } \\
a, b, c, d, e, f, g \text { and } h \\
\text { are the parameters } \\
\text { determined based on } \\
\text { regression analysis. }\end{array}$ & - & $\begin{array}{l}\text { Triaxial cyclic tests took } \\
\text { place on the limestone, } \\
\text { dolomite and gravel } \\
\text { samples (materials used in } \\
\text { base, sub-base and } \\
\text { subgrade layers treated in } \\
\text { Illinois); } \\
\text { The cohesion and friction } \\
\text { angle were determined for } \\
\text { three confining stresses. }\end{array}$ \\
\hline $\begin{array}{l}\text { QS1 } \\
\text { Silty sand with } \\
\text { high fine } \\
\text { content }\end{array}$ & $\begin{array}{c}\text { SM } \\
\text { Silty sand }\end{array}$ & $\begin{array}{l}\text { Rahman and } \\
\text { Erlingsson } \\
\quad(2015) \\
\text { and } \\
\text { Salour and } \\
\text { Erlingsson } \\
\text { (2016) }\end{array}$ & $\begin{array}{l}\varepsilon_{p}(N)=\alpha N^{b S_{f}} S_{f} \\
S_{f}=\frac{\left(\frac{q}{p_{a}}\right)}{\left(\frac{p}{p_{a}}\right)^{\alpha}}\end{array}$ & $\begin{array}{l}q \text { is deviatoric stress; } \\
p \text { is mean stress; } \\
p_{a} \text { atmospheric } \\
\text { pressure; } \\
a, b \text { and } \alpha \text { are the } \\
\text { regression parameters. }\end{array}$ & $\begin{array}{l}\mathrm{C}_{\mathrm{u}} \approx 28 ; \mathrm{C}_{\mathrm{c}} \approx 0.54 ; \\
\mathrm{G}_{\mathrm{s}}=2.68 ; \\
\text { Fine } \\
\text { content }=42.2 \% ; \\
\text { Maximum dry } \\
\text { density }=19.6 \\
\mathrm{kN} / \mathrm{m}^{3} ; \\
\mathrm{W}_{\text {opt }}=10.1 \%\end{array}$ & \multirow{2}{*}{$\begin{array}{l}\text { The triaxial tests were } \\
\text { carried out by considering } \\
\text { the constant confining } \\
\text { stress; } \\
\text { They considered high } \\
\text { stress levels and reduced } \\
\text { stress levels. }\end{array}$} \\
\hline $\begin{array}{l}\text { QS1 } \\
\text { Silty sand with } \\
\text { high fine } \\
\text { content }\end{array}$ & $\begin{array}{c}\text { SM } \\
\text { Silty sand }\end{array}$ & $\begin{array}{l}\text { Rahman and } \\
\text { Erlingsson } \\
\text { (2015) } \\
\text { and }\end{array}$ & $\begin{array}{l}\varepsilon_{p}(N)=\alpha N^{b S_{f}} S_{f} \\
S_{f}=\frac{\left(\frac{q}{p_{a}}\right)}{\left(\frac{p}{p_{a}}\right)^{\alpha}}\end{array}$ & $\begin{array}{l}q \text { is deviatoric stress; } \\
p \text { is mean stress; } \\
p_{a} \text { atmospheric } \\
\text { pressure; }\end{array}$ & $\begin{array}{l}\mathrm{C}_{\mathrm{u}} \approx 33 ; \mathrm{C}_{\mathrm{c}} \approx 0.75 ; \\
\mathrm{G}_{\mathrm{s}}=2.67 ; \\
\text { Fine } \\
\text { content }=27.4 \%\end{array}$ & \\
\hline
\end{tabular}




\begin{tabular}{|c|c|c|c|c|c|c|}
\hline & & $\begin{array}{c}\text { Salour and } \\
\text { Erlingsson } \\
\quad(2016)\end{array}$ & & $\begin{array}{l}a, b \text { and } \alpha \text { are the } \\
\text { regression parameters. }\end{array}$ & $\begin{array}{l}\text { Maximum dry } \\
\text { density }=20.3 \\
\mathrm{kN} / \mathrm{m}^{3} ; \\
\mathrm{W}_{\text {opt }}=7.6 \%\end{array}$ & \\
\hline QS2 & $\begin{array}{c}\text { SP } \\
\text { Poorly } \\
\text { graded sand }\end{array}$ & $\begin{array}{l}\text { Huurman } \\
\text { (1997) }\end{array}$ & $\begin{array}{c}\varepsilon_{1}^{p}(N)=A\left[\left(\frac{N}{1000}\right)^{B}\right] \\
+C \\
\cdot\left(e^{D \cdot \frac{N}{1000}}\right. \\
-1)\end{array}$ & $\begin{array}{l}A, B, C, D \text { are } \\
\text { parameters function of } \\
\text { stress level and stress } \\
\text { ratio }\left(\sigma_{1} / \sigma_{1 ; \mathrm{f}}\right) .\end{array}$ & $\begin{array}{l}\mathrm{C}_{\mathrm{u}}=1.69 ; \mathrm{C}_{\mathrm{c}}=1.39 ; \\
\text { Maximum dry } \\
\text { Density }=16.68 \\
\mathrm{kN} / \mathrm{m}^{3} ; \\
\mathrm{W}_{\mathrm{opt}}=12.5 \% ; \\
\mathrm{c}=4.08 \mathrm{kPa} ; \\
\phi=43.9^{0}\end{array}$ & \multirow{4}{*}{$\begin{array}{l}\text { Cyclic triaxial tests were } \\
\text { carried out on the sands } \\
\text { used in the base layers; } \\
\text { The samples were } \\
\text { subjected to a confining } \\
\text { stress equal to } 12 \mathrm{kPa} \\
\text { (corresponds to a depth } \\
\text { equal to } 0.60 \mathrm{~m} \text { ); } \\
\text { During the test, a million } \\
\text { cycles were applied } \\
\text { (frequency equal to } 5 \mathrm{~Hz} \text { ). }\end{array}$} \\
\hline QS2 & $\begin{array}{c}\text { SP } \\
\text { Poorly } \\
\text { graded sand }\end{array}$ & $\begin{array}{l}\text { Huurman } \\
\text { (1997) }\end{array}$ & $\begin{array}{c}\varepsilon_{1}^{p}(N)=A\left[\left(\frac{N}{1000}\right)^{B}\right] \\
+C \\
\cdot\left(e^{D \cdot \frac{N}{1000}}\right. \\
-1)\end{array}$ & $\begin{array}{l}A, B, C, D \text { are } \\
\text { parameters function of } \\
\text { stress level and stress } \\
\text { ratio }\left(\sigma_{1} / \sigma_{1 ; f}\right) .\end{array}$ & $\begin{array}{l}\mathrm{C}_{\mathrm{u}}=1.69 ; \\
\mathrm{C}_{\mathrm{c}}=0.998 ; \\
\text { Maximum dry } \\
\text { Density }=16.73 \\
\mathrm{kN} / \mathrm{m}^{3} ; \\
\mathrm{W}_{\mathrm{opt}}=13.0 \% ; \\
\mathrm{c}=6.76 \mathrm{kPa} ; \\
\phi=43.0^{0} .\end{array}$ & \\
\hline QS2 & $\begin{array}{c}\text { SP } \\
\text { Poorly } \\
\text { graded sand }\end{array}$ & $\begin{array}{l}\text { Huurman } \\
\text { (1997) }\end{array}$ & $\begin{array}{c}\varepsilon_{1}^{p}(N)=A\left[\left(\frac{N}{1000}\right)^{B}\right] \\
+C \\
\cdot\left(e^{D \cdot \frac{N}{1000}}\right. \\
-1)\end{array}$ & $\begin{array}{l}A, B, C, D \text { are } \\
\text { parameters function of } \\
\text { stress level and stress } \\
\text { ratio }\left(\sigma_{1} / \sigma_{1 ; \mathrm{f}}\right) .\end{array}$ & $\begin{array}{l}\mathrm{C}_{\mathrm{u}}=1.88 ; \mathrm{C}_{\mathrm{c}}=1.04 ; \\
\text { Maximum dry } \\
\text { Density }=16.56 \\
\mathrm{kN} / \mathrm{m}^{3} \\
\mathrm{~W}_{\text {opt }}=14.0 \% ; \\
\mathrm{c}=6.34 \mathrm{kPa} ; \\
\phi=41.8^{0} ;\end{array}$ & \\
\hline QS2 & $\begin{array}{c}\text { SP } \\
\text { Poorly } \\
\text { graded sand }\end{array}$ & $\begin{array}{l}\text { Huurman } \\
\text { (1997) }\end{array}$ & $\begin{array}{c}\varepsilon_{1}^{p}(N)=A\left[\left(\frac{N}{1000}\right)^{B}\right] \\
+C \\
\cdot\left(e^{D \cdot \frac{N}{1000}}\right. \\
-1)\end{array}$ & $\begin{array}{l}A, B, C, D \text { are } \\
\text { parameters function of } \\
\text { stress level and stress } \\
\text { ratio }\left(\sigma_{1} / \sigma_{1 ; \mathrm{f}}\right) .\end{array}$ & $\begin{array}{l}\mathrm{C}_{\mathrm{u}}=2.10 ; \mathrm{C}_{\mathrm{c}}=1.05 \\
\text { Maximum dry } \\
\text { Density }=16.90 \\
\mathrm{kN} / \mathrm{m}^{3} ; \\
\mathrm{W}_{\mathrm{opt}}=12.5 \%\end{array}$ & \\
\hline
\end{tabular}




\begin{tabular}{|c|c|c|c|c|c|c|}
\hline & & & & & $\begin{array}{l}\mathrm{c}=5.60 \mathrm{kPa} ; \\
\phi=48.2 ;\end{array}$ & \\
\hline QS2 & $\begin{array}{c}\text { SP } \\
\text { Poorly } \\
\text { graded sand }\end{array}$ & $\begin{array}{l}\text { Huurman } \\
\text { (1997) }\end{array}$ & $\begin{array}{r}\varepsilon_{1}^{p}(N)=A\left[\left(\frac{N}{1000}\right)^{B}\right] \\
+C \\
\cdot\left(e^{D \cdot \frac{N}{1000}}\right. \\
-1)\end{array}$ & $\begin{array}{l}A, B, C, D \text { are } \\
\text { parameters function of } \\
\text { stress level and stress } \\
\text { ratio }\left(\sigma_{1} / \sigma_{1 ; \mathrm{f}}\right)\end{array}$ & $\begin{array}{l}\mathrm{C}_{\mathrm{u}}=1.70 ; \mathrm{C}_{\mathrm{c}}=1.10 ; \\
\text { Maximum dry } \\
\text { Density }=15.61 \\
\mathrm{kN} / \mathrm{m}^{3} ; \\
\mathrm{W}_{\text {opt }}=14.50 \% \\
\mathrm{c}=7.19 \mathrm{kPa} ; \\
\phi=42.8^{0} ;\end{array}$ & \\
\hline QS2 & $\begin{array}{c}\text { SP } \\
\text { Poorly } \\
\text { graded sand }\end{array}$ & $\begin{array}{l}\text { Huurman } \\
\text { (1997) }\end{array}$ & $\begin{array}{r}\varepsilon_{1}^{p}(N)=A\left[\left(\frac{N}{1000}\right)^{B}\right] \\
+C \\
\cdot\left(e^{D \cdot \frac{N}{1000}}\right. \\
-1)\end{array}$ & $\begin{array}{l}A, B, C, D \text { are } \\
\text { parameters function of } \\
\text { stress level and stress } \\
\text { ratio }\left(\sigma_{1} / \sigma_{1 ; f}\right) .\end{array}$ & $\begin{array}{l}\mathrm{C}_{\mathrm{u}}=2.35 ; \mathrm{C}_{\mathrm{c}}=1.14 ; \\
\text { Maximum dry } \\
\text { Density }=16.16 \\
\mathrm{kN} / \mathrm{m}^{3} ; \\
\mathrm{W}_{\text {opt }}=14.5 \% ; \\
\mathrm{c}=7.99 \mathrm{kPa} ; \\
\phi=39.7^{0} .\end{array}$ & \multirow{2}{*}{$\begin{array}{l}\text { Cyclic triaxial tests took } \\
\text { place on the sands used in } \\
\text { the base layers; } \\
\text { The samples were } \\
\text { subjected to a confining } \\
\text { stress equal to } 12 \mathrm{kPa} \\
\text { (corresponds to a depth } \\
\text { equal to } 0.60 \mathrm{~m} \text { ); } \\
\text { During the test, a million } \\
\text { cycles were applied } \\
\text { (frequency equal to } 5 \mathrm{~Hz} \text { ). }\end{array}$} \\
\hline QS2 & $\begin{array}{c}\text { SP } \\
\text { Poorly } \\
\text { graded sand }\end{array}$ & $\begin{array}{l}\text { Huurman } \\
\text { (1997) }\end{array}$ & $\begin{array}{c}\varepsilon_{1}^{p}(N)=A\left[\left(\frac{N}{1000}\right)^{B}\right] \\
+C \\
\cdot\left(e^{D \cdot \frac{N}{1000}}\right. \\
-1)\end{array}$ & $\begin{array}{l}A, B, C, D \text { are } \\
\text { parameters function of } \\
\text { stress level and stress } \\
\text { ratio }\left(\sigma_{1} / \sigma_{1 ; f}\right) .\end{array}$ & $\begin{array}{l}\mathrm{C}_{\mathrm{u}}=3.76 ; \mathrm{C}_{\mathrm{c}}=1.37 ; \\
\text { Maximum dry } \\
\text { Density }=16.16 \\
\mathrm{kN} / \mathrm{m}^{3} ; \\
\mathrm{W}_{\text {opt }}=13.5 \% ; \\
\mathrm{c}=7.48 \mathrm{kPa} ; \\
\phi=42.9^{0} ;\end{array}$ & \\
\hline QS2 & $\begin{array}{c}\text { SP } \\
\text { Poorly } \\
\text { graded sand }\end{array}$ & $\begin{array}{l}\text { Sweere } \\
(1990)\end{array}$ & $\begin{array}{l}\log \left(\varepsilon_{1}^{p}(N)\right) \\
=a+b \log (N)\end{array}$ & $\begin{array}{l}a, b-\text { material } \\
\text { parameters } \\
\text { for each stress level, } \\
\text { separate permanent } \\
\text { strain parameters } a \text { and } \\
b \text { need to be } \\
\text { determined from the } \\
\text { results of the cyclic } \\
\text { load triaxial test. }\end{array}$ & $\begin{array}{l}\text { Density }=16.79 \\
\mathrm{kN} / \mathrm{m}^{3} \\
\mathrm{C}_{\mathrm{u}}=1.68 \\
\mathrm{C}_{\mathrm{c}}=1.10\end{array}$ & $\begin{array}{l}\text { Application of } 10^{6} \text { cyclic } \\
\text { loads during the triaxial } \\
\text { cyclic tests; } \\
\text { The samples consisted of } \\
\text { granular materials used in } \\
\text { the base layers, and sands; } \\
\text { The } U G M \text { samples were } \\
\text { subjected to triaxial cyclic } \\
\text { tests. }\end{array}$ \\
\hline
\end{tabular}




\begin{tabular}{|c|c|c|c|c|c|c|}
\hline & & & & $\begin{array}{l}\text { **The Sweeres's } \\
\text { formula is valid for } \\
\text { granular materials } \\
\text { (Gidel et al., 2001). }\end{array}$ & & \\
\hline $\begin{array}{c}\mathrm{QS} 2 \\
\mathrm{Sa}(>0.063 \text { to } \\
2)\end{array}$ & $\begin{array}{c}\text { SP } \\
\text { Poorly } \\
\text { graded sand }\end{array}$ & $\begin{array}{c}\text { Puppala et al. } \\
\text { (2009) }\end{array}$ & $\begin{array}{l}\varepsilon^{p} \\
=\alpha_{1} N^{\alpha_{2}}\left(\frac{\sigma_{o c t}}{P_{\text {ref }}}\right)^{\alpha_{3}}\left(\frac{\tau_{\text {oct }}}{P_{\text {ref }}}\right)^{\alpha}-\end{array}$ & $\begin{array}{l}\alpha_{1}, \alpha_{2}, \alpha_{3} \text { and } \alpha_{4} \text { are the } \\
\text { model constants } \\
\text { determined from } \\
\text { laboratory tests; } \\
\sigma_{o c t} \text { and } \tau_{o c t} \text { are the } \\
\text { octahedral normal and } \\
\text { shear stresses, } \\
\text { respectively; } \\
P_{\text {ref }} \text { is the reference } \\
\text { stress. }\end{array}$ & $\begin{array}{l}\mathrm{W}_{\mathrm{L}}=26.40 \% ; \\
\mathrm{G}_{\mathrm{s}}=2.71 \% ; \\
\text { Passing } \\
\# 200=0.70 \% ; \\
\mathrm{C}_{\mathrm{u}}=1.79 ; \mathrm{C}_{\mathrm{c}}=0.89 ; \\
\text { Maximum dry unit } \\
\text { weight }=15.70 \\
\mathrm{kN} / \mathrm{m}^{3} ; \\
\mathrm{W}_{\text {opt }}=13.70 \% ; \\
\mathrm{c}=20 \mathrm{kPa} ; \\
\phi=42^{\circ} ;\end{array}$ & $\begin{array}{l}\text { The model is based on } \\
10,000 \text { cycles, and } \\
\text { includes the effects of } \\
\text { mean and shear stresses; } \\
\text { The model was tested } \\
\text { based on the cyclic triaxial } \\
\text { tests; } \\
\text { The permanent } \\
\text { deformation of clay, silt } \\
\text { and sand were measured } \\
\text { using the soil samples } \\
\text { compacted with different } \\
\text { water content. }\end{array}$ \\
\hline $\begin{array}{l}\text { QS2 } \\
\text { Gravelly sand } \\
\quad(\mathrm{SaGr})\end{array}$ & $\begin{array}{c}\text { SP } \\
\text { Sand poorly } \\
\text { graded }\end{array}$ & $\begin{array}{l}\text { Chen et al. } \\
\text { (2014) }\end{array}$ & $\begin{array}{l}\varepsilon_{1}^{p}(N) \\
=\varepsilon_{1}^{p 0}[1 \\
\left.-e^{-B N}\right]\left(\frac{\sqrt{p_{a m^{2}}+q_{a m}^{2}}}{p_{a}}\right) \\
\frac{1}{m\left(1+\frac{p_{\text {ini }}}{p_{a m}}\right)+\frac{s}{p_{a m}}-\frac{\left(q_{\text {ini }}\right.}{}}\end{array}$ & $\begin{array}{l}\varepsilon_{1}^{p}(N) \text { is the strain } \\
\text { settlement; } \\
\varepsilon_{1}^{p 0}, B, a, s \text { and } m \text { are } \\
\text { material parameters; } \\
p_{a}=100 \mathrm{kPa} \text {; } \\
p_{\text {ini }} \text { and } q_{\text {ini }} \text { are the } \\
\text { mean and deviator } \\
\text { stress in the initial state } \\
\text { of the layer; } \\
p_{a m} \text { and } q_{a m} \text { are the } \\
\text { amplitude of mean } \\
\text { stress and deviator } \\
\text { stress for train } \\
\text { loadings, respectively. }\end{array}$ & $\begin{array}{l}\mathrm{G}_{\mathrm{s}}=2.66 ; \\
\mathrm{C}_{\mathrm{u}}=4.8 ; \mathrm{C}_{\mathrm{c}}=0.62 ; \\
\text { Maximum dry } \\
\text { density }=20.69 \\
\mathrm{kN} / \mathrm{m}^{3} ; \\
\text { Minimum dry } \\
\text { density }=15.89 \\
\mathrm{kN} / \mathrm{m}^{3} ; \\
\text { Hydraulic } \\
\text { permeability }= \\
3.2 \times 10^{-5} \mathrm{~m} / \mathrm{s} ; \\
\mathrm{c}^{\prime}=0 \mathrm{kPa} ; \\
\phi^{\prime}=33^{\circ} .\end{array}$ & $\begin{array}{l}\text { The model is based on } \\
\text { Gidel's model (Gidel et } \\
\text { al., 2001); } \\
\text { It considered the direct } \\
\text { influence of the initial } \\
\text { stress state. }\end{array}$ \\
\hline
\end{tabular}




\begin{tabular}{|c|c|c|c|c|c|c|}
\hline $\begin{array}{c}\mathrm{QS} 2 \\
\mathrm{Sa}(>0.063 \text { to } \\
2) \\
\text { Fine sand }\end{array}$ & $\begin{array}{c}\text { SP } \\
\text { Poorly } \\
\text { graded sand }\end{array}$ & $\begin{array}{c}\text { Cai et al. } \\
\text { (2015) }\end{array}$ & $\begin{array}{l}\varepsilon_{z}^{p} \\
=\alpha_{1} N^{\alpha_{2}}\left(\frac{\sigma_{o c t}}{\sigma_{a t m}}\right)^{\alpha_{3}}\left(\frac{\tau_{o c t}}{\sigma_{a t m}}\right)^{\alpha-} \\
\left(\sqrt{1+4 \eta^{2}}\right)^{\alpha_{5}}\end{array}$ & $\begin{array}{l}\alpha_{1}, \alpha_{2}, \alpha_{3}, \alpha_{4} \text { and } \alpha_{5} \text { are } \\
\text { constants of the model } \\
\text { and determined through } \\
\text { laboratory tests; } \\
\sigma_{o c t} \text { and } \tau_{o c t} \text { are the } \\
\text { normal and shear } \\
\text { octahedral stresses, } \\
\text { respectively; } \\
\sigma_{a t m} \text { is the reference } \\
\text { stress } \\
\eta \text { is the cyclic torsional } \\
\text { stress ratio. }\end{array}$ & $\begin{array}{l}\mathrm{G}_{\mathrm{s}}=2.70 ; \\
\mathrm{C}_{\mathrm{u}} \approx 1.63 ; \\
\mathrm{C}_{\mathrm{c}} \approx 0.89 ; \\
\mathrm{D}_{50}=0.17 \mathrm{~mm} ; \\
\mathrm{e}_{\max }=1.142 ; \mathrm{e}_{\min }=0 . \\
628\end{array}$ & $\begin{array}{l}\text { The model is based on a } \\
\text { series of tests using the } \\
\text { hollow cylinder apparatus. } \\
\text { The permanent } \\
\text { deformation of a sand was } \\
\text { studied in drained } \\
\text { conditions by considering } \\
\text { different levels of } \\
\text { confining stress, and the } \\
\text { ratios of cyclic vertical } \\
\text { stress and cyclic torsional } \\
\text { stress; } \\
\text { This model was developed } \\
\text { to incorporate the rotation } \\
\text { of principal stresses. }\end{array}$ \\
\hline QS2 & $\begin{array}{c}\text { SP } \\
\text { Poorly- } \\
\text { graded sand }\end{array}$ & $\begin{array}{l}\text { Lekarp and } \\
\text { Dawson } \\
(1998)\end{array}$ & $\frac{\varepsilon_{1}^{p}\left(N_{\text {ref }}\right)}{\left(L / p_{0}\right)}=a \cdot\left(\frac{q}{p}\right)_{\max }^{b}$ & $\begin{array}{l}a \text { and } b: \\
N_{r e f} ; \\
L=\sqrt{\mathrm{q}^{2}+\mathrm{p}^{2}} \\
p_{0}=100 \mathrm{kPa} \\
\text { (reference mean stress). }\end{array}$ & $\begin{array}{l}\text { Dry density }=14.91 \\
\mathrm{kN} / \mathrm{cm}^{3} ; \\
\mathrm{C}_{\mathrm{u}} \approx 1.5 \\
\mathrm{C}_{\mathrm{c}} \approx 1.0\end{array}$ & $\begin{array}{l}\text { Triaxial cyclic tests and } \\
\text { hollow cylinder tests were } \\
\text { carried out on limestone, } \\
\text { sand and gravel. }\end{array}$ \\
\hline QS2 & $\begin{array}{c}\text { SP } \\
\text { Poorly- } \\
\text { graded sand }\end{array}$ & $\begin{array}{l}\text { Qian et al. } \\
\text { (2019a) }\end{array}$ & $\begin{array}{l}\varepsilon_{N}^{a c c} \\
=\left(\alpha_{1} \Delta \gamma+\alpha_{2}\right)+\left(\alpha_{3} \Delta \gamma\right. \\
\left.+\alpha_{4}\right) \ln \frac{N}{100}\end{array}$ & $\begin{array}{l}\varepsilon_{N}^{a c c} \text { is the } \mathrm{N}^{\text {th }} \text { vertical } \\
\text { accumulative strain in } \\
\text { percentage; } \\
N \text { is the number of loo } \\
\Delta \gamma \text { is the calculated } \\
\text { shear strain amplitude } \\
\text { in percentage } \\
\alpha_{1}-\alpha_{4} \text { are model } \\
\text { parameters }\end{array}$ & $\begin{array}{l}\mathrm{G}_{\mathrm{s}}=2.54 ; \\
\mathrm{C}_{\mathrm{u}} \approx 1.65 ; \\
\mathrm{C}_{\mathrm{c}} \approx 1 ; \\
\mathrm{D}_{50}=0.16 \mathrm{~mm} \\
\mathrm{e}_{\max } \approx 0.931 ; \\
\mathrm{e}_{\min } \approx 0.611\end{array}$ & $\begin{array}{l}\text { Drained cyclic triaxial } \\
\text { tests with different levels } \\
\text { of initial mean effective } \\
\text { stress }\left(p_{s}\right) \text {, relative density } \\
\left(D_{r}\right), \text { initial static stress } \\
\text { ratio }\left(\mathrm{n}_{\mathrm{s}}\right) \text { and cyclic stress } \\
\text { ratio were performed on } \\
\text { saturated Toyoura sand. } \\
\text { Indeed, the effects of } \\
\text { cyclic stress ratio and } \\
\text { initial mean effective }\end{array}$ \\
\hline
\end{tabular}




\begin{tabular}{|c|c|c|c|c|c|c|}
\hline & & & & & & $\begin{array}{l}\text { stress on the permanent } \\
\text { deformation; } \\
\text { The estimated permanent } \\
\text { strains show a good } \\
\text { agreement with the } \\
\text { measured data. The } \\
\text { deviation between the } \\
\text { estimation and the } \\
\text { measurement is less than } \\
20 \% \text {. }\end{array}$ \\
\hline QS3 & $\begin{array}{c}\text { SP } \\
\text { Poorly } \\
\text { graded sand }\end{array}$ & Hyde (1974) & $\varepsilon_{1}^{p}=a \frac{q}{\sigma_{3}}$ & $\begin{array}{l}\mathrm{a} \text { is a constant; } \\
\sigma_{3} \text { is the confining } \\
\text { stress; } \\
\mathrm{q} \text { is deviator stress. }\end{array}$ & $\begin{array}{l}\mathrm{Gs}=2.72 ; \\
\mathrm{C}_{\mathrm{u}} \approx 16 ; \\
\mathrm{C}_{\mathrm{c}} \approx 0.69 ; \\
\text { Maximum dry } \\
\text { densisty }=21.76 \\
\mathrm{kN} / \mathrm{m}^{3} ; \\
\mathrm{W}_{\mathrm{opt}}=7.5 \pm 0.5 \% ;\end{array}$ & $\begin{array}{l}\text { The tests were carried out } \\
\text { under a constant and } \\
\text { variable confining stress; } \\
\text { During the analysis, the } \\
\text { behaviour of the marl was } \\
\text { studied; } \\
\text { The author states that the } \\
\text { results would be the same } \\
\text { if medium confining stress } \\
\text { was applied. }\end{array}$ \\
\hline QS3 & $\begin{array}{c}\text { SP } \\
\text { Poorly- } \\
\text { graded sand }\end{array}$ & $\begin{array}{l}\text { Lekarp and } \\
\text { Dawson } \\
(1998)\end{array}$ & $\frac{\varepsilon_{1}^{p}\left(N_{r e f}\right)}{\left(L / p_{0}\right)}=a \cdot\left(\frac{q}{p}\right)_{\max }^{b}$ & $\begin{array}{l}a \text { and } b: \\
N_{r e f} ; \\
L=\sqrt{\mathrm{q}^{2}+\mathrm{p}^{2}} \\
p_{0}=100 \mathrm{kPa} \\
\text { (reference mean stress). }\end{array}$ & $\begin{array}{l}\text { Dry density }=20.10 \\
\mathrm{kN} / \mathrm{m}^{3} \\
\mathrm{C}_{\mathrm{u}} \approx 32 \\
\mathrm{C}_{\mathrm{c}} \approx 0.2\end{array}$ & $\begin{array}{l}\text { Triaxial cyclic tests and } \\
\text { hollow cylinder tests were } \\
\text { carried out on limestone, } \\
\text { sand and gravel. }\end{array}$ \\
\hline $\begin{array}{c}\text { QS3 } \\
\mathrm{Sa}(>0.063 \text { to } \\
2)\end{array}$ & $\begin{array}{c}\text { SW } \\
\text { Well-graded } \\
\text { sand }\end{array}$ & $\begin{array}{c}\text { Puppala et al. } \\
\text { (1999) }\end{array}$ & $\begin{array}{l}\log \varepsilon^{p} \\
=\log A \\
+\alpha \log N+\beta \log \left(\frac{\sigma_{o c t}}{\sigma_{a t m}}\right)\end{array}$ & $\begin{array}{l}A, \beta \text { and } \alpha \text { are soil } \\
\text { parameters; } \\
\sigma_{o c t} \text { and } \tau_{o c t} \text { are the } \\
\text { octahedral normal and } \\
\text { shear stresses, } \\
\text { respectively. }\end{array}$ & $\%$ sand $=100$ & $\begin{array}{l}\text { The model was tested } \\
\text { based on triaxial tests; } \\
\text { During his study, well- } \\
\text { graded sand, silty clay and } \\
\text { clay were considered. }\end{array}$ \\
\hline
\end{tabular}




\begin{tabular}{|c|c|c|c|c|c|c|}
\hline QS3 & $\begin{array}{c}\text { SW } \\
\text { Well-graded } \\
\text { sand }\end{array}$ & $\begin{array}{l}\text { Huurman } \\
\text { (1997) }\end{array}$ & $\begin{array}{c}\varepsilon_{1}^{p}(N)=A\left[\left(\frac{N}{1000}\right)^{B}\right] \\
+C \\
\cdot\left(e^{D \cdot \frac{N}{1000}}\right. \\
-1)\end{array}$ & $\begin{array}{l}A, B, C, D \text { are } \\
\text { parameters function of } \\
\text { stress level and stress } \\
\text { ratio }\left(\sigma_{l} / \sigma_{l ; f}\right)\end{array}$ & $\begin{array}{l}\mathrm{C}_{\mathrm{u}}=10.5 ; \mathrm{C}_{\mathrm{c}}=1.25 ; \\
\text { Maximum dry } \\
\text { Density }=17.21 \\
\mathrm{kN} / \mathrm{m}^{3} ; \\
\mathrm{W}_{\text {opt }}=10.5 \% ; \\
\mathrm{c}=8.68 \mathrm{kPa} ; \\
\phi=50.2^{0} .\end{array}$ & $\begin{array}{l}\text { Cyclic triaxial tests were } \\
\text { carried out on the sands } \\
\text { used in the base layers; } \\
\text { The samples were } \\
\text { subjected to a confining } \\
\text { stress equal to } 12 \mathrm{kPa} \\
\text { (corresponds to a depth } \\
\text { equal to } 0.60 \mathrm{~m} \text { ); } \\
\text { During the test, a million } \\
\text { cycles were applied } \\
\text { (frequency equal to } 5 \mathrm{~Hz} \text { ). }\end{array}$ \\
\hline
\end{tabular}


Table 4. Permanent deformation model for granular soils (gravels and sandy gravels)

\begin{tabular}{|c|c|c|c|c|c|c|}
\hline UIC & $\begin{array}{c}\text { ASTM } \\
\text { classification }\end{array}$ & $\begin{array}{c}\text { Author's } \\
\text { model }\end{array}$ & $\begin{array}{c}\text { Equation } \\
\text { model }\end{array}$ & $\begin{array}{c}\text { Variables and } \\
\text { Empirical Constants }\end{array}$ & $\begin{array}{c}\text { Parameters and } \\
\text { characteristics }\end{array}$ & Observations \\
\hline $\begin{array}{c}\text { QS2 } \\
\text { Sandy gravel } \\
(\mathrm{GrSa}) \\
\mathrm{C}_{\mathrm{u}} \approx 200 ; \\
\mathrm{C}_{\mathrm{c}} \approx 0.8\end{array}$ & $\begin{array}{l}\text { GP-GM/GC } \\
\text { Poorly- } \\
\text { graded sandy } \\
\text { gravel } \\
\text { (no } \\
\text { information } \\
\text { about the } \\
\text { fines) }\end{array}$ & $\begin{array}{l}\text { Rahman } \\
\text { and } \\
\text { Erlingsson } \\
\text { (2015) }\end{array}$ & $\begin{array}{l}\varepsilon_{p}(N)=\alpha N^{b S_{f}} S_{f} \\
S_{f}=\frac{\left(\frac{q}{p_{a}}\right)}{\left(\frac{p}{p_{a}}\right)^{\alpha}}\end{array}$ & $\begin{array}{l}q \text { is deviatoric stress; } \\
-\quad p \text { is mean stress; } \\
p_{a} \text { atmospheric } \\
\text { pressure; } \\
-\quad a, b \text { and } \alpha \text { are the } \\
\text { regression parameters. }\end{array}$ & $\begin{array}{l}\mathrm{G}_{\mathrm{s}}=2.54 ; \\
\text { Maximum dry } \\
\text { density }=21.67 \\
\mathrm{kN} / \mathrm{m}^{3} ; \\
\text { Fines Content }= \\
10.2 \% ; \\
\mathrm{W}_{\text {opt }}=6 \% .\end{array}$ & \multirow{4}{*}{$\begin{array}{l}\text { The triaxial tests took } \\
\text { place by considering } \\
\text { constant confining stress; } \\
\text { The tests considered high } \\
\text { stress levels and reduced } \\
\text { stress levels. }\end{array}$} \\
\hline $\begin{array}{c}\text { QS2 } \\
\text { Sandy gravel } \\
(\mathrm{GrSa}) \\
\mathrm{C}_{\mathrm{u}} \approx 73 ; \\
\mathrm{C}_{\mathrm{c}} \approx 1.5\end{array}$ & $\begin{array}{c}\text { GW-GM/GC } \\
\text { Well-graded } \\
\text { sandy gravel } \\
\text { (no } \\
\text { information } \\
\text { about the } \\
\text { fines) }\end{array}$ & $\begin{array}{l}\text { Rahman } \\
\text { and } \\
\text { Erlingsson } \\
\text { (2015) }\end{array}$ & $\begin{array}{l}\varepsilon_{p}(N)=\alpha N^{b S_{f}} S_{f} \\
S_{f}=\frac{\left(\frac{q}{p_{a}}\right)}{\left(\frac{p}{p_{a}}\right)^{\alpha}}\end{array}$ & $\begin{array}{l}q \text { is deviatoric stress; } \\
-\quad p \text { is mean stress; } \\
p_{a} \text { atmospheric } \\
\text { pressure; } \\
-\quad a, b \text { and } \alpha \text { are the } \\
\text { regression parameters. }\end{array}$ & $\begin{array}{l}\mathrm{G}_{\mathrm{s}}=2.68 ; \\
\text { Fines Content }= \\
8.6 \% ; \\
\text { Maximum dry } \\
\text { density } \\
=23.05 \mathrm{kN} / \mathrm{m}^{3} ; \\
\mathrm{W}_{\text {opt }}=6.9 \% .\end{array}$ & \\
\hline $\begin{array}{c}\text { QS2 } \\
\text { Sandy gravel } \\
(\mathrm{GrSa}) \\
\mathrm{C}_{\mathrm{u}} \approx 98 \\
\mathrm{C}_{\mathrm{c}} \approx 2.8\end{array}$ & $\begin{array}{c}\text { GW-GM/GC } \\
\text { Well-graded } \\
\text { sandy gravel } \\
\text { (no } \\
\text { information } \\
\text { about the } \\
\text { fines) }\end{array}$ & $\begin{array}{l}\text { Rahman } \\
\text { and } \\
\text { Erlingsson } \\
\text { (2015) }\end{array}$ & $\begin{array}{l}\varepsilon_{p}(N)=\alpha N^{b S_{f}} S_{f} \\
S_{f}=\frac{\left(\frac{q}{p_{a}}\right)}{\left(\frac{p}{p_{a}}\right)^{\alpha}}\end{array}$ & $\begin{array}{l}q \text { is deviatoric stress; } \\
-\quad p \text { is mean stress; } \\
-p_{a} \text { atmospheric } \\
\text { pressure; } \\
-\quad a, b \text { and } \alpha \text { are the } \\
\text { regression parameters. }\end{array}$ & $\begin{array}{l}\mathrm{G}_{\mathrm{s}}=2.64 ; \\
\text { Fines Content }= \\
6.5 \% ; \\
\text { Maximum dry } \\
\text { density }=22.16 \\
\mathrm{kN} / \mathrm{m}^{3} ; \\
\mathrm{W}_{\text {opt }}=6 \% .\end{array}$ & \\
\hline $\begin{array}{c}\text { QS2 } \\
\text { Sandy gravel } \\
(\mathrm{GrSa})\end{array}$ & $\begin{array}{c}\text { GW-GM/GC } \\
\text { Well-graded } \\
\text { sandy gravel } \\
\text { (no }\end{array}$ & $\begin{array}{l}\text { Rahman } \\
\text { and } \\
\text { Erlingsson } \\
(2015)\end{array}$ & $\varepsilon_{p}(N)=\alpha N^{b S_{f}} S_{f}$ & $\begin{array}{l}-q \text { is deviatoric stress; } \\
-\quad p \text { is mean stress; } \\
\text { - } p_{a} \text { atmospheric } \\
\text { pressure; }\end{array}$ & $\begin{array}{l}\mathrm{G}_{\mathrm{s}}=2.64 ; \\
\text { Fines Content }= \\
12 \%\end{array}$ & \\
\hline
\end{tabular}




\begin{tabular}{|c|c|c|c|c|c|c|}
\hline $\begin{aligned} \mathrm{C}_{\mathrm{u}} & \approx 117 \\
\mathrm{C}_{\mathrm{c}} & \approx 2.2\end{aligned}$ & $\begin{array}{l}\text { information } \\
\text { about the } \\
\text { fines) }\end{array}$ & & $S_{f}=\frac{\left(\frac{q}{p_{a}}\right)}{\left(\frac{p}{p_{a}}\right)^{\alpha}}$ & $\begin{array}{l}a, b \text { and } \alpha \text { are the } \\
\text { regression parameters. }\end{array}$ & $\begin{array}{l}\text { Maximum dry } \\
\text { density }=21.77 \\
\mathrm{kN} / \mathrm{m}^{3} ; \\
\mathrm{W}_{\text {opt }}=6.5 \% .\end{array}$ & \\
\hline $\begin{array}{l}\text { QS2-QS3 } \\
\text { (average to } \\
\text { good soils) } \\
\text { Classification } \\
\text { based on the } \\
\text { LA and MDE } \\
\text { results. }\end{array}$ & - & $\begin{array}{c}\text { Gidel et al. } \\
\text { (2001) }\end{array}$ & $\begin{array}{l}\varepsilon_{p}(N) \\
=\varepsilon^{0}\left[1-\left(\frac{N}{100}\right)^{-B}\right] \\
\times\left(\frac{L_{\text {máx }}}{p_{a}}\right)^{u}\left(m+\frac{s}{p_{\max }}\right. \\
\left.-\frac{q_{\max }}{p_{\max }}\right)^{-1}\end{array}$ & $\begin{array}{l}\mathcal{E}^{0}, B \text { and } u \text { are material } \\
\text { parameters } \\
p_{\text {max }} \text { and } q_{\text {max }} \text { are the } \\
\text { maxima applied } \\
\text { hydrostatic stress and } \\
\text { the deviator stress, } \\
\text { respectively. } \\
s \text { is the intercept of the } \\
\text { Mohr-Coulomb failure } \\
\text { line in the } p-q \text { space } \\
m \text { is the slope of this } \\
\text { failure line } \\
-p_{a} \text { correspond to the } \\
\text { reference stress (100 } \\
\text { kPa). } \\
\text { The value } L_{\max } \text { is } \\
\text { calculated considering } \\
\text { the following } \\
\text { expression: } \\
-\quad L_{\text {max }}= \\
\sqrt{p_{\text {max }}{ }^{2}+q_{\text {max }}}\end{array}$ & $\begin{array}{l}0 / 20 \mathrm{~mm} \\
\text { (limestone } \\
\text { unbound } \\
\text { granular } \\
\text { material); } \\
\mathrm{LA}=22 ; \\
\mathrm{MDE}=15 ; \\
\mathrm{p}_{\mathrm{dSPO}}=2450 \\
\mathrm{~kg} / \mathrm{m} 3 ; \\
\mathrm{W}_{\mathrm{SPO}}=4.4 \% \text {; } \\
\text { Fines } \\
\text { content }=10 \% \text {; } \\
\mathrm{D}=160 \mathrm{~mm} ; \\
\mathrm{H}=320 \mathrm{~mm} .\end{array}$ & $\begin{array}{l}\text { This model is based on } \\
\text { cyclic triaxial tests on } \\
\text { two samples where the } \\
\text { particles had different } \\
\text { dimensions: hard } \\
\text { limestone }(0 / 20 \mathrm{~mm}) \text { and } \\
\text { microgranite }(0 / 10 \mathrm{~mm}) \text {; } \\
\text { - The tests included } \\
\text { several load levels }(40) \text { at } \\
\text { almost } 20,000 \text { cycles. }\end{array}$ \\
\hline
\end{tabular}




\begin{tabular}{|c|c|c|c|c|c|c|}
\hline $\begin{array}{l}\text { QS2-QS3 } \\
\text { (average to } \\
\text { good soils) } \\
\text { Classification } \\
\text { of the } \\
\text { subgrade } \\
\text { (based on the } \\
\text { LA and MDE } \\
\text { results): }\end{array}$ & - & $\begin{array}{l}\text { Gidel et al. } \\
\text { (2001) }\end{array}$ & $\begin{array}{l}\varepsilon_{p}(N) \\
=\varepsilon^{0}\left[1-\left(\frac{N}{100}\right)^{-B}\right] \\
\times\left(\frac{L_{\text {máx }}}{p_{a}}\right)^{u}\left(m+\frac{s}{p_{\max }}\right. \\
\left.-\frac{q_{\max }}{p_{\max }}\right)^{-1}\end{array}$ & $\begin{array}{l}\varepsilon^{0}, B \text { and } u \text { are material } \\
\text { parameters } \\
p_{\max } \text { and } q_{\max } \text { are the } \\
\text { maxima applied } \\
\text { hydrostatic stress and } \\
\text { the deviator stress, } \\
\text { respectively. } \\
s \text { is the intercept of the } \\
\text { Mohr-Coulomb failure } \\
\text { line in the } p-q \text { space } \\
m \text { is the slope of this } \\
\text { failure line } \\
p_{a} \text { correspond to the } \\
\text { reference stress (100 } \\
\mathrm{kPa} \text { ). } \\
\text { The value } L_{\max } \text { is } \\
\text { calculated considering } \\
\text { the following } \\
\text { expression: } \\
L_{\text {máx }} \\
=\sqrt{p_{\text {max }}{ }^{2}+q_{\text {max }}{ }^{2}}\end{array}$ & $\begin{array}{l}0 / 10 \mathrm{~mm} \\
\text { (granular } \\
\text { material } \\
\text { obtained from } \\
\text { microgranite); } \\
\mathrm{LA}=20 ; \\
\mathrm{MDE}=13 ; \\
\mathrm{p}_{\mathrm{dSPO}}=2200 \\
\mathrm{~kg} / \mathrm{m} 3 ; \\
\mathrm{W}_{\mathrm{SPO}}=6.3 \% \\
\text { Fines } \\
\text { content }=7.8 \% \text {; } \\
\mathrm{D}=76.2 \mathrm{~mm} .\end{array}$ & \\
\hline $\begin{array}{c}\text { QS2 - QS3 } \\
\text { Sandy gravel } \\
\text { (GrSa) }\end{array}$ & $\begin{array}{c}\text { GW } \\
\text { Well-graded } \\
\text { gravel }\end{array}$ & $\begin{array}{l}\text { Ling et al. } \\
\text { (2017) }\end{array}$ & $\varepsilon_{a c c}(N)=f_{a m p l} f_{n} f_{p} f_{N}$ & $\begin{array}{l}f_{\text {ampl }} \text { describes the range } \\
\text { intensity of } P D \text { with the } \\
\text { increase of the cyclic } \\
\text { stress amplitude; } \\
f_{p} \text { represents the } \\
\text { influence of the initial } \\
\text { mean stress; } \\
f_{n} \text { represents the } \\
\text { influence of the initial } \\
\text { stress ratio; }\end{array}$ & $\begin{array}{l}\mathrm{C}_{\mathrm{u}} \approx 60 ; \\
\mathrm{C}_{\mathrm{c}} \approx 1.3 ; \\
\text { Sand } \\
\text { content=40\%; } \\
\text { Gravel content } \\
=60 \% ;\end{array}$ & $\begin{array}{l}\text { The study focused on } \\
\text { granular materials. }\end{array}$ \\
\hline
\end{tabular}




\begin{tabular}{|c|c|c|c|c|c|c|}
\hline & & & & $\begin{array}{l}f_{N} \text { characterizes the } \\
\text { trend of the variation's } \\
\text { deformation with the } \\
\text { number of cyclic loads. }\end{array}$ & & \\
\hline QS3 & $\begin{array}{c}\text { GP } \\
\text { Poorly- } \\
\text { graded gravel }\end{array}$ & $\begin{array}{l}\text { Lekarp and } \\
\text { Dawson } \\
\text { (1998) }\end{array}$ & $\frac{\varepsilon_{1}^{p}\left(N_{r e f}\right)}{\left(L / p_{0}\right)}=a \cdot\left(\frac{q}{p}\right)_{\max }^{b}$ & $\begin{array}{l}a \text { and } b ; \\
N_{r e f} ; \\
L=\sqrt{\mathrm{q}^{2}+\mathrm{p}^{2}} ; \\
p_{0}=100 \mathrm{kPa} \\
\text { (reference mean } \\
\text { stress). }\end{array}$ & $\begin{array}{l}\text { Dry } \\
\text { density }=21.18 \\
\mathrm{kN} / \mathrm{m}^{3} \\
\mathrm{C}_{\mathrm{u}} \approx 92 \\
\mathrm{C}_{\mathrm{c}} \approx 6.4\end{array}$ & $\begin{array}{l}\text { Triaxial cyclic tests and } \\
\text { hollow cylinder tests took } \\
\text { place on limestone, sand } \\
\text { and gravel. }\end{array}$ \\
\hline $\begin{array}{c}\text { QS3 } \\
\text { Sandy gravel } \\
(\mathrm{GrSa}) \\
\mathrm{C}_{\mathrm{u}} \approx 26 ; \\
\mathrm{C}_{\mathrm{c}} \approx 0.9\end{array}$ & $\begin{array}{c}\text { GP } \\
\text { Poorly- } \\
\text { graded sandy } \\
\text { gravel }\end{array}$ & $\begin{array}{l}\text { Rahman } \\
\text { and } \\
\text { Erlingsson } \\
(2015)\end{array}$ & $\begin{array}{l}\varepsilon_{p}(N)=\alpha N^{b S_{f}} S_{f} \\
S_{f}=\frac{\left(\frac{q}{p_{a}}\right)}{\left(\frac{p}{p_{a}}\right)^{\alpha}}\end{array}$ & $\begin{array}{l}q \text { is deviatoric stress; } \\
-\quad p \text { is mean stress; } \\
-\quad p_{a} \text { atmospheric } \\
\text { pressure; } \\
-\quad a, b \text { and } \alpha \text { are the } \\
\text { regression parameters. }\end{array}$ & $\begin{array}{l}\mathrm{G}_{\mathrm{s}}=2.49 ; \\
\text { Fines Content } \\
(<0.075 \mathrm{~mm})= \\
3.8 \% ; \\
\mathrm{W}_{\text {opt }}=7.5 \% ; \\
\text { Maximum dry } \\
\text { density }=20.89 \\
\mathrm{kN} / \mathrm{m}^{3} \text {. }\end{array}$ & \multirow{2}{*}{$\begin{array}{l}\text { The triaxial tests } \\
\text { considered constant } \\
\text { confining stress; } \\
\text { The tests also considered } \\
\text { high stress levels and } \\
\text { reduced stress levels. }\end{array}$} \\
\hline $\begin{array}{c}\text { QS3 } \\
\text { Sandy gravel } \\
(\mathrm{GrSa}) \\
\mathrm{C}_{\mathrm{u}} \approx 35 ; \\
\mathrm{C}_{\mathrm{c}} \approx 4.6\end{array}$ & $\begin{array}{c}\text { GP } \\
\text { Poorly- } \\
\text { graded sandy } \\
\text { gravel }\end{array}$ & $\begin{array}{l}\text { Rahman } \\
\text { and } \\
\text { Erlingsson } \\
(2015)\end{array}$ & $\begin{array}{l}\varepsilon_{p}(N)=\alpha N^{b S_{f}} S_{f} \\
S_{f}=\frac{\left(\frac{q}{p_{a}}\right)}{\left(\frac{p}{p_{a}}\right)^{\alpha}}\end{array}$ & $\begin{array}{l}q \text { is deviatoric stress; } \\
-\quad p \text { is mean stress; } \\
-\quad p_{a} \text { atmospheric } \\
\text { pressure; } \\
\quad a, b \text { and } \alpha \text { are the } \\
\text { regression parameters. }\end{array}$ & $\begin{array}{l}\text { Fines Content } \\
(<0.075 \mathrm{~mm})= \\
1.4 \% ; \\
\mathrm{W}_{\text {opt }}=5 \% ; \\
\mathrm{Gs}=2.61 ; \\
\text { Maximum dry } \\
\text { density }=21.18 \\
\mathrm{kN} / \mathrm{m}^{3} .\end{array}$ & \\
\hline QS3 & $\begin{array}{c}\text { GW } \\
\text { Well-graded } \\
\text { Gravel }\end{array}$ & $\begin{array}{l}\text { Lekarp and } \\
\text { Dawson } \\
(1998)\end{array}$ & $\frac{\varepsilon_{1}^{p}\left(N_{r e f}\right)}{\left(L / p_{0}\right)}=a \cdot\left(\frac{q}{p}\right)_{\max }^{b}$ & {$\left[\begin{array}{l}a \text { and } b ; \\
\quad N_{r e f} ; \\
L=\sqrt{\mathrm{q}^{2}+\mathrm{p}^{2}}\end{array}\right.$} & $\begin{array}{l}\text { Dry } \\
\text { density }=20.50 \\
\mathrm{kN} / \mathrm{m}^{3} \\
\mathrm{Cu} \approx 75 \\
\mathrm{Cc} \approx 1.3\end{array}$ & $\begin{array}{l}\text { Triaxial cyclic tests and } \\
\text { hollow cylinder tests took } \\
\text { place on limestone, sand } \\
\text { and gravel. }\end{array}$ \\
\hline
\end{tabular}




\begin{tabular}{|c|c|c|c|c|c|c|}
\hline & & & & $\begin{array}{l}p_{0}=100 \mathrm{kPa} \\
\text { (reference mean } \\
\text { stress); }\end{array}$ & & \\
\hline QS3 & $\begin{array}{c}\text { GW } \\
\text { Well-graded } \\
\text { Gravel }\end{array}$ & $\begin{array}{l}\text { Lekarp and } \\
\text { Dawson } \\
(1998)\end{array}$ & $\frac{\varepsilon_{1}^{p}\left(N_{r e f}\right)}{\left(L / p_{0}\right)}=a \cdot\left(\frac{q}{p}\right)_{\max }^{b}$ & \begin{tabular}{|l}
$a$ and $b ;$ \\
$N_{r e f}$ \\
$L=\sqrt{\mathrm{q}^{2}+\mathrm{p}^{2}}$ \\
$p_{0}=100 \mathrm{kPa}$ \\
(reference mean \\
stress).
\end{tabular} & $\begin{array}{l}\text { Dry } \\
\text { density }=22.16 \\
\mathrm{kN} / \mathrm{m}^{3} \\
\mathrm{Cu} \approx 55 \\
\mathrm{Cc} \approx 1.3\end{array}$ & \\
\hline $\begin{array}{c}\text { QS3 } \\
\text { Sandy gravel } \\
(\mathrm{GrSa}) \\
\mathrm{C}_{\mathrm{u}} \approx 16 ; \\
\mathrm{C}_{\mathrm{c}} \approx 1.6\end{array}$ & $\begin{array}{c}\text { GW } \\
\text { Well-graded } \\
\text { sandy gravel }\end{array}$ & $\begin{array}{l}\text { Rahman } \\
\text { and } \\
\text { Erlingsson } \\
\text { (2015) }\end{array}$ & $\begin{array}{l}\varepsilon_{p}(N)=\alpha N^{b S_{f}} S_{f} \\
S_{f}=\frac{\left(\frac{q}{p_{a}}\right)}{\left(\frac{p}{p_{a}}\right)^{\alpha}}\end{array}$ & $\begin{array}{ll}- & q \text { is deviatoric stress; } \\
- & p \text { is mean stress; } \\
- & p_{a} \text { atmospheric } \\
\text { pressure; } & \\
- & a, b \text { and } \alpha \text { are the } \\
& \text { regression parameters. }\end{array}$ & $\begin{array}{l}\mathrm{G}_{\mathrm{s}}=2.64 ; \\
\text { Fines Content= } \\
2.4 \% ; \\
\text { Maximum dry } \\
\text { density }=20.59 \\
\mathrm{kN} / \mathrm{m}^{3} ; \\
\mathrm{W}_{\text {opt }}=5.5 \% .\end{array}$ & \multirow{2}{*}{$\begin{array}{l}\text { The triaxial tests } \\
\text { considered constant } \\
\text { confining stress; } \\
\text { The tests also considered } \\
\text { high tress levels and } \\
\text { reduced stress levels. }\end{array}$} \\
\hline $\begin{array}{c}\text { QS3 } \\
\text { Sandy gravel } \\
(\mathrm{GrSa}) \\
\mathrm{C}_{\mathrm{u}} \approx 20 ; \\
\mathrm{C}_{\mathrm{c}} \approx 1.5\end{array}$ & $\begin{array}{c}\text { GW } \\
\text { Well-graded } \\
\text { sandy gravel }\end{array}$ & $\begin{array}{l}\text { Rahman } \\
\text { and } \\
\text { Erlingsson } \\
(2015)\end{array}$ & $\begin{array}{l}\varepsilon_{p}(N)=\alpha N^{b S_{f}} S_{f} \\
S_{f}=\frac{\left(\frac{q}{p_{a}}\right)}{\left(\frac{p}{p_{a}}\right)^{\alpha}}\end{array}$ & $\begin{array}{l}-\quad q \text { is deviatoric stress; } \\
-\quad p \text { is mean stress; } \\
-\quad p_{a} \text { atmospheric } \\
\text { pressure; } \\
-\quad a, b \text { and } \alpha \text { are the } \\
\text { regression parameters. }\end{array}$ & $\begin{array}{l}\mathrm{G}_{\mathrm{s}}=2.63 ; \\
\text { Fines Content }= \\
2.2 \% \text {; } \\
\text { Maximum dry } \\
\text { density }=20.35 \\
\mathrm{kN} / \mathrm{m}^{3} ; \\
\mathrm{W}_{\text {opt }}=5.5 \% .\end{array}$ & \\
\hline QS3 & $\begin{array}{c}\text { GW } \\
\text { Well-graded } \\
\text { Grave } \\
\text { (granite } \\
\text { aggregate) }\end{array}$ & $\begin{array}{c}\text { Gu et al. } \\
\text { (2016) }\end{array}$ & $\begin{array}{l}\varepsilon^{p} \\
=\varepsilon_{0} e^{-\left(\frac{\rho}{N}\right)}\left(\sqrt{J_{2}}\right)^{m}\left(\alpha I_{1}\right. \\
+K)^{n} \\
\alpha=\frac{2 \sin \emptyset}{\sqrt{3}(3-\sin \emptyset)} \\
K=\frac{c \cdot 6 \cos \emptyset}{\sqrt{3}(3-\sin \emptyset)}\end{array}$ & $\begin{array}{l}J_{2} \text { is the second } \\
\text { invariant of the } \\
\text { deviatoric stress } \\
\text { tensor; } \\
-\quad I_{1} \text { is the first invariant } \\
\text { of the stress tensor; } \\
-\quad c \text { and } \phi \text { are the } \\
\text { cohesion and friction } \\
\text { angle, respectively; }\end{array}$ & $\begin{array}{l}\gamma_{\mathrm{d}}=2.162 \mathrm{~kg} / \mathrm{m}^{3} ; \\
\omega=6.7 \% ; \\
\mathrm{PI}=4 ; \mathrm{LL}=25 ; \\
\phi=51.3^{\circ} ; \mathrm{c}=20.2 \\
\mathrm{kPa} ; \\
\mathrm{C}_{\mathrm{u}} \approx 25 ; \mathrm{C}_{\mathrm{c}} \approx 2.8 .\end{array}$ & $\begin{array}{l}\text { This model used the } \\
\text { shear strength ratio and } \\
\text { stress terms in the } \\
\text { Drucker-Prager model to } \\
\text { construct a stress- } \\
\text { dependent model; } \\
\text { The stress term } \sqrt{J_{2}} \\
\text { represents the softing }\end{array}$ \\
\hline
\end{tabular}




\begin{tabular}{|c|c|c|c|c|c|c|}
\hline & & & & $\begin{array}{l}-\quad \varepsilon_{0}, \rho, \beta, m \text { and } n \text { are } \\
\text { model coefficients. }\end{array}$ & & $\begin{array}{l}\text { effects that deviatoric } \\
\text { shear stress has on the }\end{array}$ \\
\hline QS3 & $\begin{array}{c}\text { GW } \\
\text { Well-graded } \\
\text { Gravel } \\
\text { (limestone } \\
\text { conglomerate } \\
\text { aggregate) }\end{array}$ & $\begin{array}{l}\text { Gu et al. } \\
\text { (2016) }\end{array}$ & $\begin{array}{l}\varepsilon^{p} \\
=\varepsilon_{0} e^{-\left(\frac{\rho}{N}\right)}\left(\sqrt{J_{2}}\right)^{m}\left(\alpha I_{1}\right. \\
+K)^{n} \\
\alpha=\frac{2 \sin \emptyset}{\sqrt{3}(3-\sin \emptyset)} \\
K=\frac{c \cdot 6 \cos \emptyset}{\sqrt{3}(3-\sin \emptyset)}\end{array}$ & 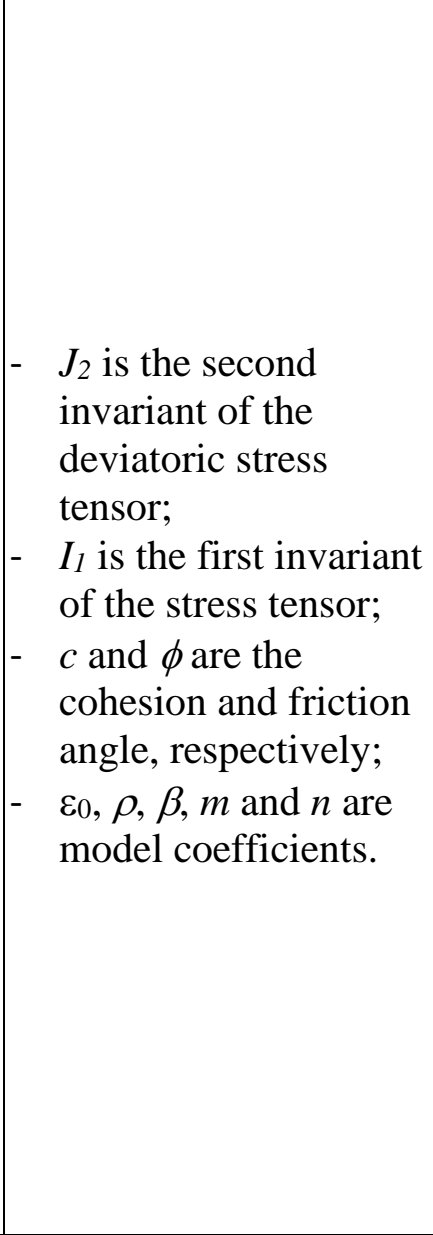 & $\begin{array}{l}\gamma_{\mathrm{d}}=1.934 \mathrm{~kg} / \mathrm{m}^{3} ; \\
\omega=13.5 \% ; \\
\mathrm{PI}=\text { non-plastic; } \\
\text { LL=not } \\
\text { applicable; } \\
\phi=54.9^{\circ} ; \mathrm{c}=66.2 \\
\mathrm{kPa} ; \\
\mathrm{C}_{\mathrm{u}} \approx 45 ; \mathrm{C}_{\mathrm{c}} \approx 1.25 .\end{array}$ & $\begin{array}{l}\text { value yields larger } \\
\text { permanent deformation; } \\
\text { The power } m \text { is always } \\
\text { positive and the term } \\
\alpha I_{1}+K \text { indicates the } \\
\text { hardening/strengthening } \\
\text { effect that hydrostatic } \\
\text { stress has on UGM; it is } \\
\text { highly affected by the } \\
\text { strength parameter } \\
\text { (cohesion and friction } \\
\text { angle); } \\
\text { A higher value of } \alpha I_{1}+ \\
K \text { leads to smaller plastic } \\
\text { deformation. The power } \\
n \text { is always a negative } \\
\text { number. The authors } \\
\text { carried out a compressive } \\
\text { strength test to determine } \\
\text { the cohesion, the friction } \\
\text { angle, and also } \alpha \text { and } K \\
\text { by plotting the diagram } \\
\sqrt{J_{2}}-I_{1} \text { and Repeated } \\
\text { Load Triaxial Tests } \\
\text { (N=10,000 cycles). }\end{array}$ \\
\hline
\end{tabular}


Table 5. Empirical models dependent on the number of load cycles

\begin{tabular}{|c|c|c|}
\hline Authors & Permanent Strains & Parameters \\
\hline $\begin{array}{c}\text { Barksdale } \\
\text { (1972) }\end{array}$ & $\varepsilon_{1}^{p}=a+b \log (N)$ & $a$ and $b$ are constants \\
\hline Khedr (1985) & $\frac{\varepsilon_{1}^{p}}{N}=A \cdot N^{-b}$ & $\begin{array}{l}b \text { is a material parameter } \\
A \text { is a material and stress- } \\
\text { strain parameter given as a } \\
\text { function of shear stress ratio } \\
\text { and resilient modulus }\end{array}$ \\
\hline Paute (1988) & $\varepsilon_{1}^{p}=A_{0} \frac{\sqrt{N}}{\sqrt{N}+D}+\varepsilon_{1}^{p}(100)$ & $\begin{array}{l}A_{0}-\text { parameter function of } \\
\text { the stress level, } \\
D \text { is a regression parameter } \\
\varepsilon_{1}^{p}(100)-\text { permanent } \\
\text { deformation after the first } \\
100 \text { cycles }\end{array}$ \\
\hline $\begin{array}{l}\text { Tseng and } \\
\text { Lytton } \\
\text { (1989b) }\end{array}$ & $\varepsilon^{p}=\varepsilon_{0}^{p} e^{-\left(\frac{\rho}{N}\right)}$ & $\begin{array}{l}\varepsilon_{p} \text { is the permanent strain } \\
\varepsilon_{0}^{p} \text { is the maximum } \\
\text { permanent strain } \\
N \text { is the number of load } \\
\text { cycles } \\
\rho \text { is the scale factor } \\
\beta \text { is the shape factor }\end{array}$ \\
\hline $\begin{array}{l}\text { Sweere } \\
(1990)\end{array}$ & $\log \left(\varepsilon_{1}^{p}(N)\right)=a+b \log (N)$ & $\begin{array}{l}\text { a,b-material parameters } \\
\text { * for each stress level, separate } \\
\text { permanent strain parameters } a \\
\text { and } b \text { need to be determined } \\
\text { from the results of cyclic load } \\
\text { triaxial test }\end{array}$ \\
\hline
\end{tabular}




\begin{tabular}{c|c|l}
\hline & & $\begin{array}{l}* * \text { The Sweeres's formula is } \\
\text { valid for granular materials } \\
\text { Gidel et al., 2001) }\end{array}$ \\
\hline $\begin{array}{c}\text { Hornych } \\
(1993)\end{array}$ & $\varepsilon_{1}^{p}(N)=A\left[1-\left(\frac{N}{100}\right)^{-B}\right]$ & $\begin{array}{l}A \text { and } B \\
\varepsilon_{1}^{\mathrm{p}}(100)-\text { permanent } \\
\text { deformation after the first } \\
100 \text { cycles }\end{array}$ \\
\hline $\begin{array}{c}\text { Vuong } \\
\text { (1994) }\end{array}$ & $\varepsilon_{1}^{p}(100)$ & $\begin{array}{l}a, b \text { and } c \\
\varepsilon_{1}^{r} \text { is the resilient axial strain }\end{array}$ \\
\hline $\begin{array}{c}\text { Wolff and } \\
\text { Visser (1994) }\end{array}$ & $\varepsilon_{1}^{p}=(c N+a)\left(1-e^{-b N}\right)$ & $\begin{array}{l}a, b \text { and } c \text { are regression } \\
\text { parameters }\end{array}$ \\
\hline $\begin{array}{c}\text { Huurman } \\
\text { (1997) }\end{array}$ & $\varepsilon_{1}^{p}(N)=A\left[\left(\frac{N}{1000}\right)^{B}\right]+C$ & $\begin{array}{l}A, B, C, D \text { are parameters } \\
\text { function of stress level }\end{array}$ \\
$\cdot\left(e^{\left.D \cdot \frac{N}{1000}-1\right)}\right.$ &
\end{tabular}


Table 6. Empirical permanent deformation models dependent on the number of load cycles and stress levels

\begin{tabular}{|c|c|c|}
\hline Authors & Permanent Strains & Parameters \\
\hline $\begin{array}{c}\text { Barksdale } \\
\text { (1972) }\end{array}$ & $\begin{array}{l}\varepsilon_{1}^{p} \\
=\frac{q / a \cdot \sigma_{3}^{b}}{1-\left[\frac{R_{f} \cdot q \cdot(1-\sin \emptyset)}{2\left(C \cdot \cos \varnothing+\sigma_{3} \sin \varnothing\right)}\right]}\end{array}$ & $\begin{array}{l}a . \sigma_{3}^{b} \text { is a relationship defining } \\
\text { the initial tangent modulus as a } \\
\text { function of confining pressure } \\
\left(\sigma_{3}\right) ; a \text { and } b \text { are constants } \\
R_{f} \text { is the ratio of the applied } \\
\text { deviator stress at failure } \mathrm{q}_{\mathrm{f}} \\
\phi \text { is the friction angle and } C \text { is } \\
\text { the cohesion }\end{array}$ \\
\hline Hyde (1974) & $\varepsilon_{1}^{p}=a \frac{q}{\sigma_{3}}$ & $\begin{array}{l}a \text { is a constant; } \\
\sigma_{3} \text { is the confining stress; } \\
q \text { is deviator stress. }\end{array}$ \\
\hline $\begin{array}{l}\text { Shenton } \\
\text { (1974) }\end{array}$ & $\varepsilon_{1}^{p}=K\left(\frac{q_{\max }}{\sigma_{3}}\right)^{\alpha}$ & $\begin{array}{l}K \text { and } \alpha \\
q_{\max } \text { is the maximum deviatoric } \\
\text { stress applied }\end{array}$ \\
\hline Pappin (1979) & $\varepsilon_{1}^{p}=f_{n}(N) \cdot L \cdot\left(\frac{q^{0}}{p^{0}}\right)^{2.8}$ & $\begin{array}{l}f_{n}(N)-\text { depends on the number } \\
\text { of cycles (shape factor); } \\
q^{0} \text { is the modified deviator stress } \\
(\sqrt{2 / 3} \cdot q) \\
p^{O} \text { is the modified mean normal } \\
\text { stress }(\sqrt{3} \cdot p) \\
L=\sqrt{p^{2}+q^{2}} \text { (length of stress } \\
\text { path) }\end{array}$ \\
\hline $\begin{array}{c}\text { Lentz and } \\
\text { Baladi (1980) }\end{array}$ & $\begin{array}{c}\varepsilon_{1}^{p}=\varepsilon_{0.95 S} \ln \left(1-\frac{q}{S}\right)^{-0.15}+ \\
{\left[\frac{n(q / S)}{1-m(q / S)}\right] \ln (\mathrm{N})}\end{array}$ & $\begin{array}{l}\varepsilon_{0,95 s} \text { is the axial strain at } 95 \% \\
\text { of the deviatoric stress at failure } \\
m \text { is the slope of the failure line } \\
S \text { is the deviatoric stress at } \\
\text { failure }\end{array}$ \\
\hline
\end{tabular}




\begin{tabular}{|c|c|c|}
\hline $\begin{array}{c}\text { Tseng and } \\
\text { Lytton (1989a) }\end{array}$ & $\varepsilon_{1}^{p}=\varepsilon_{0}^{p} e^{-(\rho / N)^{\beta}}$ & $\begin{array}{l}\varepsilon^{\mathrm{p}} \text { is the permanent strain of the } \\
\text { granular material; } \\
\varepsilon_{0}^{p} \text { is the maximum permanent } \\
\text { strain; } \\
N \text { is the number of laod cycles; } \\
\rho \text { is the scale factor; } \\
\beta \text { is the shape factor. }\end{array}$ \\
\hline \multirow[t]{2}{*}{$\begin{array}{l}\text { Paute et al. } \\
\text { (1994) }\end{array}$} & \multirow[t]{2}{*}{$\begin{array}{l}\varepsilon_{1}^{p *}=f(N) \cdot A \\
=f(N) \cdot \frac{\frac{q}{\left(p+p^{*}\right)}}{(}\end{array}$} & \multirow{2}{*}{$\begin{array}{l}\varepsilon_{1}^{p *} \text { is the permanent axial strain } \\
\text { after the first } 100 \text { cycles } \\
b-\text { regression parameter } \\
p^{*} \text { is a stress parameter defined } \\
\text { by the intersection of the static } \\
\text { failure line and } p \text {-axis in } p-q \\
\text { space } \\
m \text { is the slope of the failure line } \\
\text { in } p-q \text { space } \\
f(N) \text { function of the number of } \\
\text { cycles } N\end{array}$} \\
\hline & & \\
\hline Nishi (1994) & $\varepsilon_{1, u l t}^{p}=k \frac{q^{a}}{p^{b}}$ & $\begin{array}{l}a \text { and } b \\
\varepsilon_{1, u l t}^{p} \text { is the ultimate permanent } \\
\text { axial strain }\end{array}$ \\
\hline $\begin{array}{c}\text { Lekarp and } \\
\text { Dawson } \\
\text { (1998) }\end{array}$ & $\frac{\varepsilon_{1}^{p}\left(N_{r e f}\right)}{\left(L / p_{0}\right)}=a \cdot\left(\frac{q}{p}\right)_{\max }^{b}$ & $\begin{array}{l}a \text { and } b \\
N_{r e f} \\
L=\sqrt{\mathrm{q}^{2}+\mathrm{p}^{2}}, \\
p_{0}=100 \mathrm{kPa} \text { (reference mean } \\
\text { stress) }\end{array}$ \\
\hline
\end{tabular}


Table 7. Materials selected for the preliminary analysis of the permanent deformation

\begin{tabular}{|c|c|c|c|c|}
\hline Author & Soils & $\begin{array}{c}\text { ASTM } \\
\text { Classification }\end{array}$ & $\begin{array}{c}\text { UIC } \\
\text { classification }\end{array}$ & Observations \\
\hline \multirow{2}{*}{$\begin{array}{l}\text { Chen et al. } \\
\text { (2014) }\end{array}$} & Sand & $\mathrm{SP}$ & QS2 & $\begin{array}{c}\text { Compacted at field } \\
\text { conditions and saturated }\end{array}$ \\
\hline & Silt & CL-ML & QS1 & $\begin{array}{c}\text { Compacted at field } \\
\text { conditions and saturated }\end{array}$ \\
\hline \multirow{2}{*}{$\begin{array}{c}\text { Salour and } \\
\text { Erlingsson } \\
(2016) \text { and } \\
\text { Erlingsson et al. } \\
\quad(2017)\end{array}$} & $\begin{array}{c}\text { Silty Sand } \\
\text { (42.2\% fines) }\end{array}$ & SM & QS1 & $\begin{array}{c}\text { Compacted at optimum } \\
\text { compaction - standard } \\
\text { Proctor } \\
\end{array}$ \\
\hline & $\begin{array}{c}\text { Silty Sand } \\
(27.4 \% \text { fines })\end{array}$ & $\mathrm{SM}$ & QS1 & $\begin{array}{c}\text { Compacted at optimum } \\
\text { compaction - standard } \\
\text { Proctor } \\
\end{array}$ \\
\hline \multirow{2}{*}{$\begin{array}{c}\text { Huurman } \\
\text { (1997) }\end{array}$} & $\begin{array}{l}\text { Well-graded } \\
\text { Sand }\end{array}$ & SP & QS2 & $\begin{array}{c}\text { Compacted at optimum } \\
\text { compaction - standard } \\
\text { Proctor }\end{array}$ \\
\hline & $\begin{array}{l}\text { Poor-graded } \\
\text { Sand }\end{array}$ & SW & QS3 & $\begin{array}{c}\text { Compacted at optimum } \\
\text { compaction - standard } \\
\text { Proctor }\end{array}$ \\
\hline
\end{tabular}


Table 8. Physical properties of the materials - granulometry

\begin{tabular}{c|c|c|c|c|c|c} 
Authors & \multicolumn{2}{|c|}{ Huurman (1997) } & $\begin{array}{c}\text { Salour and } \\
\text { Erlingsson (2016) } \\
\text { and Erlingsson et } \\
\text { al. (2017) }\end{array}$ & \multicolumn{2}{c}{ Chen et al. (2014) } \\
\hline $\begin{array}{c}\text { Material/ } \\
\text { Properties }\end{array}$ & $\begin{array}{c}\text { C. } \\
\text { Bruynweg }\end{array}$ & Crusher & $\begin{array}{c}\text { Silty } \\
\text { Clay } \\
\mathbf{( 4 2 . 2 \%} \\
\text { fines } \\
\text { content) }\end{array}$ & $\begin{array}{c}\text { Silty } \\
\text { Clay } \\
(\mathbf{2 7 . 4 \%} \\
\text { fines } \\
\text { content) }\end{array}$ & Silt & $\begin{array}{c}\text { Coarse } \\
\text { sand }\end{array}$ \\
\hline $\mathbf{C}_{\mathbf{u}}$ & 2.1 & 10.5 & 28 & 33 & 2.51 & 4.68 \\
\hline $\mathbf{C}_{\mathbf{c}}$ & 1.05 & 1.25 & 0.54 & 0.75 & 1.32 & 0.62 \\
\hline $\mathrm{D}_{10}$ & 0.148 & 0.217 & - & - & - & - \\
\hline $\mathrm{D}_{30}$ & 0.219 & 0.784 & - & - & - & - \\
\hline $\mathrm{D}_{50}$ & 0.280 & 1.722 & - & - & - & - \\
\hline $\mathrm{D}_{60}$ & 0.31 & 2.28 & - & - & - & - \\
\hline $\mathrm{CBR}_{(\%)}$ & 22 & 15.7 & - & - & - & - \\
\hline & & & & & &
\end{tabular}


Table 9. State conditions of the materials

\begin{tabular}{|c|c|c|c|c|c|c|}
\hline \multirow{2}{*}{$\begin{array}{c}\text { Authors } \\
\begin{array}{l}\text { Material/ } \\
\text { Properties }\end{array}\end{array}$} & \multicolumn{2}{|c|}{ Huurman (1997) } & \multicolumn{2}{|c|}{$\begin{array}{c}\text { Salour and } \\
\text { Erlingsson (2016) } \\
\text { and Erlingsson et } \\
\text { al. (2017) }\end{array}$} & \multicolumn{2}{|c|}{$\begin{array}{c}\text { Chen et al. } \\
\text { (2014) }\end{array}$} \\
\hline & $\begin{array}{c}\text { C. } \\
\text { Bruynweg }\end{array}$ & Crusher & $\begin{array}{c}\text { Silty } \\
\text { Clay } \\
(42.2 \% \\
\text { fines } \\
\text { content) }\end{array}$ & $\begin{array}{c}\text { Silty } \\
\text { Clay } \\
(27.4 \% \\
\text { fines } \\
\text { content) }\end{array}$ & Silt & $\begin{array}{c}\text { Coarse } \\
\text { sand }\end{array}$ \\
\hline $\begin{array}{l}\gamma_{\text {dry;max }} \\
\left(\mathrm{kg} / \mathrm{m}^{3}\right)\end{array}$ & 1723 & 1755 & 1998 & 2070 & 1620 & 2110 \\
\hline $\mathrm{W}_{\text {opt }}(\%)$ & 12.5 & 10.5 & 10.1 & 7.6 & - & - \\
\hline $\begin{array}{c}\gamma_{\text {wet }} \\
\left(\mathrm{kg} / \mathrm{m}^{3}\right)\end{array}$ & 1942 & 1937 & - & - & - & - \\
\hline $\begin{array}{c}\text { Liquid } \\
\text { limit }(\%)\end{array}$ & $\begin{array}{l}\text { Non- } \\
\text { plastic }\end{array}$ & $\begin{array}{l}\text { Non- } \\
\text { plastic }\end{array}$ & $\begin{array}{l}\text { Non- } \\
\text { plastic }\end{array}$ & $\begin{array}{l}\text { Non- } \\
\text { plastic }\end{array}$ & 35 & $\begin{array}{l}\text { Non- } \\
\text { plastic }\end{array}$ \\
\hline $\begin{array}{c}\text { Plastic } \\
\text { limit }\end{array}$ & $\begin{array}{l}\text { Non- } \\
\text { plastic }\end{array}$ & $\begin{array}{l}\text { Non- } \\
\text { plastic }\end{array}$ & $\begin{array}{l}\text { Non- } \\
\text { plastic }\end{array}$ & $\begin{array}{l}\text { Non- } \\
\text { plastic }\end{array}$ & 24 & $\begin{array}{l}\text { Non- } \\
\text { plastic }\end{array}$ \\
\hline
\end{tabular}


Table 10. Strength properties of the materials

\begin{tabular}{|c|c|c|c|c|c|c|}
\hline \multirow{2}{*}{$\begin{array}{c}\text { Authors } \\
\\
\text { Material/ } \\
\text { Properties }\end{array}$} & \multicolumn{2}{|c|}{ Huurman (1997) } & \multicolumn{2}{|c|}{$\begin{array}{c}\text { Salour and } \\
\text { Erlingsson (2016) } \\
\text { and Erlingsson et } \\
\text { al. (2017) }\end{array}$} & \multicolumn{2}{|c|}{ Chen et al. (2014) } \\
\hline & $\begin{array}{c}\text { C. } \\
\text { Bruynweg }\end{array}$ & Crusher & $\begin{array}{c}\text { Silty } \\
\text { Clay } \\
(42.2 \% \\
\text { fines } \\
\text { content) }\end{array}$ & $\begin{array}{c}\text { Silty } \\
\text { Clay } \\
(27.4 \% \\
\text { fines } \\
\text { content) }\end{array}$ & Silt & $\begin{array}{c}\text { Coarse } \\
\text { sand }\end{array}$ \\
\hline$\phi\left(^{(}\right)$ & 48.2 & 50.20 & 36.18 & 45.66 & $11.7 *$ & $0^{*}$ \\
\hline c (kPa) & 5.60 & 8.68 & 15.82 & 10.43 & $16.4^{*}$ & $33 *$ \\
\hline $\mathbf{s}(\mathbf{k P a})^{* * *}$ & 9.90 & 14.90 & 31.80 & 19.10 & 24.8 & 0 \\
\hline $\mathbf{m} * *$ & 1.98 & 2.07 & 1.47 & 1.88 & 0.62 & 1.33 \\
\hline
\end{tabular}

* In this case, the author described the saturated samples (silt and coarse sand)

in $\phi^{\prime}$ and $c^{\prime}$

** $s$ and $m$ are the parameters used to define the failure envelope: $q=s+m p$ 
Table 11. Parameters of Chen's model and its relationship with the ASTM and UIC classification

\begin{tabular}{|c|c|c|c|c|c} 
& $\varepsilon_{p 0}$ & $\boldsymbol{\alpha}$ & $\boldsymbol{\beta}$ & $\begin{array}{c}\text { ASTM } \\
\text { classification }\end{array}$ & $\begin{array}{c}\text { UIC } \\
\text { classificatio } \\
\text { n }\end{array}$ \\
\hline Silt (Chen et al., 2014) & 0.0029 & 0.2680 & 0.3390 & $\mathrm{CL}$ & $\mathrm{QS} 1$ \\
\hline $\begin{array}{c}\text { Silty sand (43\% fines) } \\
\text { (Erlingsson and } \\
\text { Rahman, 2013) }\end{array}$ & 0.0067 & 0.6500 & 0.2000 & $\mathrm{SM}$ & $\mathrm{QS} 1$ \\
\hline $\begin{array}{c}\text { Silty sand (27\% fines) } \\
\text { (Erlingsson and } \\
\text { Rahman, 2013) }\end{array}$ & 0.0069 & 0.6500 & 0.2000 & $\mathrm{SM}$ & $\mathrm{QS} 1$ \\
\hline $\begin{array}{c}\text { Coarse sand (Chen et } \\
\text { al., 2014) }\end{array}$ & 0.0018 & 0.3340 & 0.3390 & $\mathrm{SP}$ & $\mathrm{QS} 2$ \\
\hline $\begin{array}{c}\text { Poor-graded sand } \\
\text { (Huurman, 1997) }\end{array}$ & 0.0505 & 0.0104 & 0.0018 & $\mathrm{SP}$ & $\mathrm{QS} 2$ \\
\hline $\begin{array}{c}\text { Well-graded sand } \\
\text { (Huurman, 1997) }\end{array}$ & 0.0486 & 0.0111 & 0.0569 & $\mathrm{SW}$ & $\mathrm{QS} 3$ \\
\hline
\end{tabular}


Table 12. Properties of the clay (in optimum conditions) tested in the Puppala et al. (2009)

\begin{tabular}{|c|c|}
\hline $\begin{array}{c}\text { Properties and } \\
\text { parameters }\end{array}$ & Clay \\
\hline$\phi\left({ }^{0}\right)$ & 18 \\
\hline $\mathbf{c}(\mathbf{k P a})$ & 60 \\
\hline Liquid limit (\%) & 28.19 \\
\hline $\begin{array}{c}\text { Plasticity index } \\
(\%)\end{array}$ & 12.55 \\
\hline $\begin{array}{c}\text { Maximum dry } \\
\text { unit weight } \\
\left(\mathrm{kN} / \mathrm{m}^{3}\right)\end{array}$ & 17.10 \\
\hline $\mathrm{W}_{\text {opt }}(\%)$ & 17.11 \\
\hline$\alpha_{1}$ & 0.24 \\
\hline$\alpha_{2}$ & 0.31 \\
\hline$\alpha_{3}$ & -1.77 \\
\hline$\alpha_{4}$ & 2.85 \\
\hline
\end{tabular}




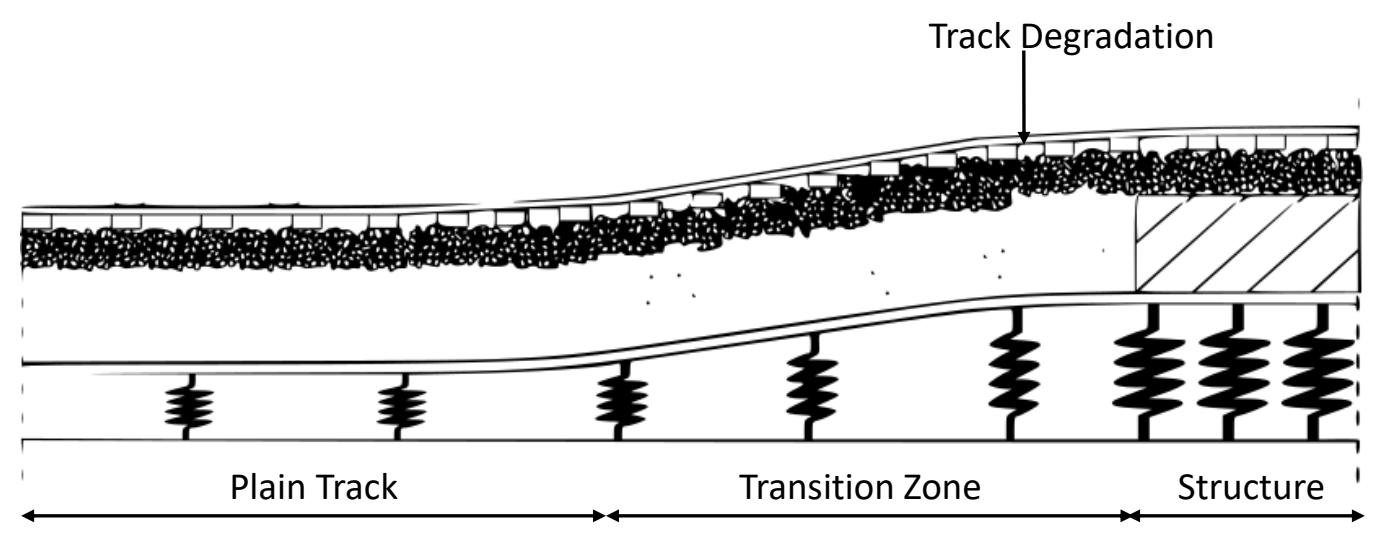

Figure 1. Example of a rail track at a transition zone 


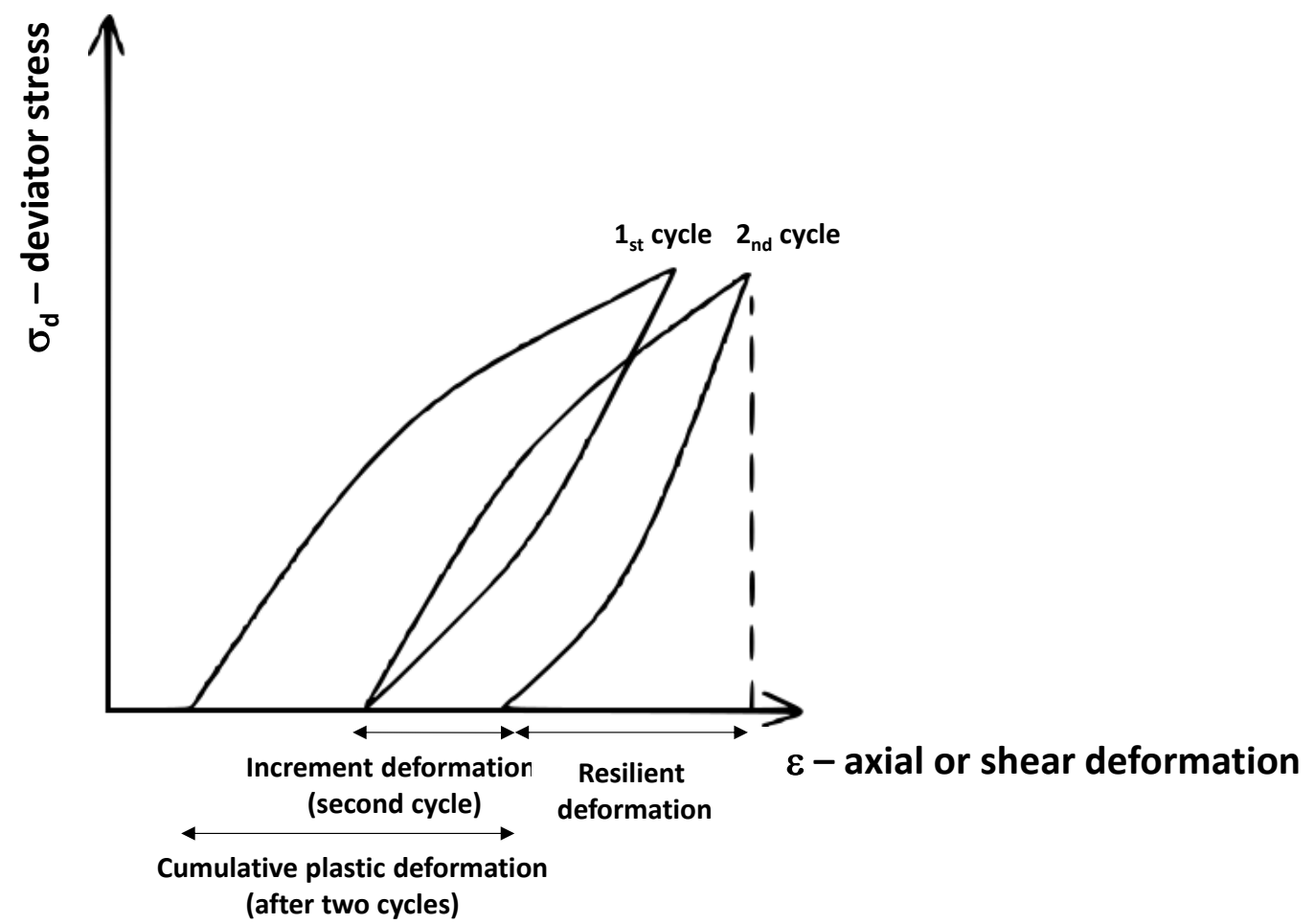

Figure 2. Illustration of the accumulation of permanent deformation under cyclic loads (after two cycles) 


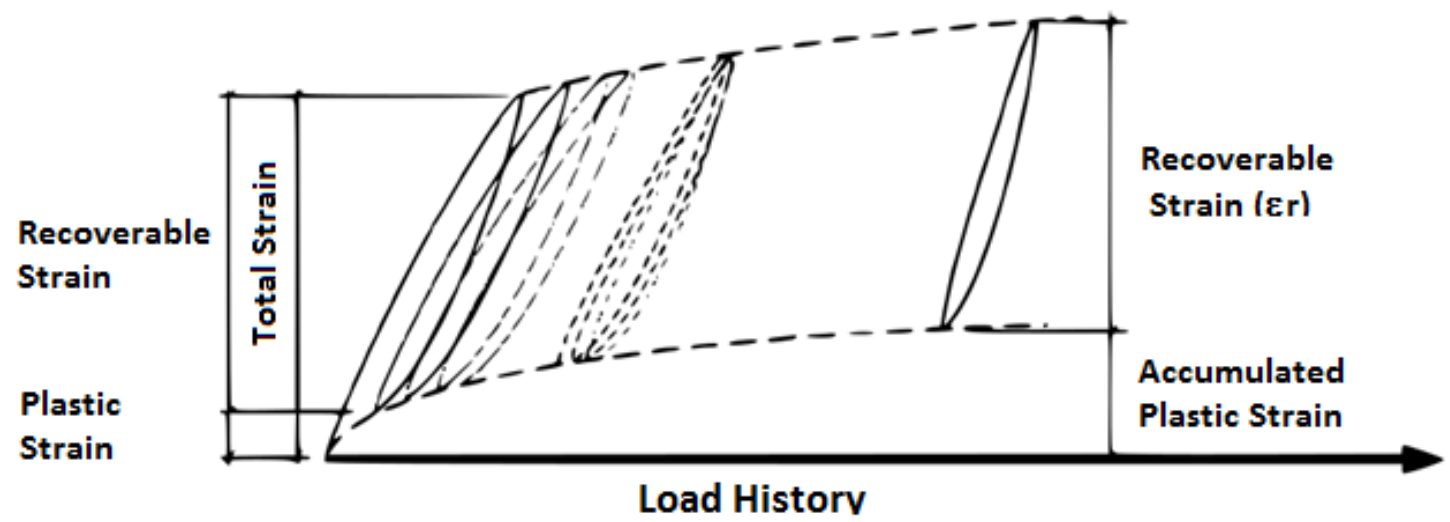

Figure 3. Accumulation of permanent strain (adapted from Erlingsson et al. (2017)

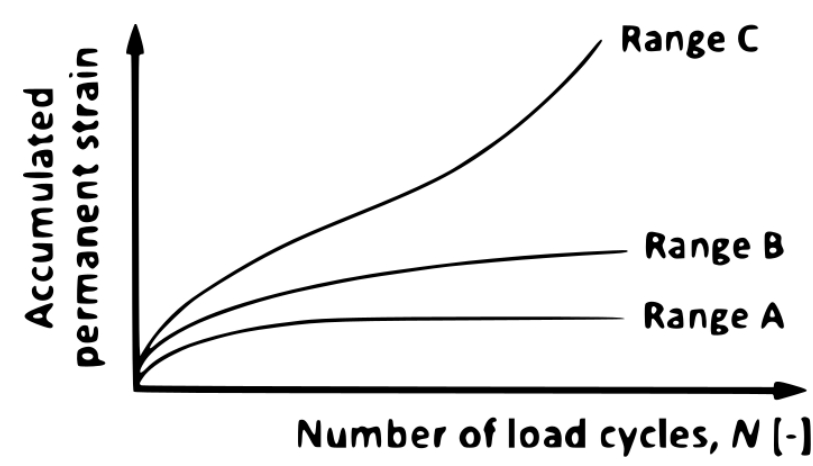

Figure 4. Illustration of shakedown theory (Erlingsson et al., 2017) 


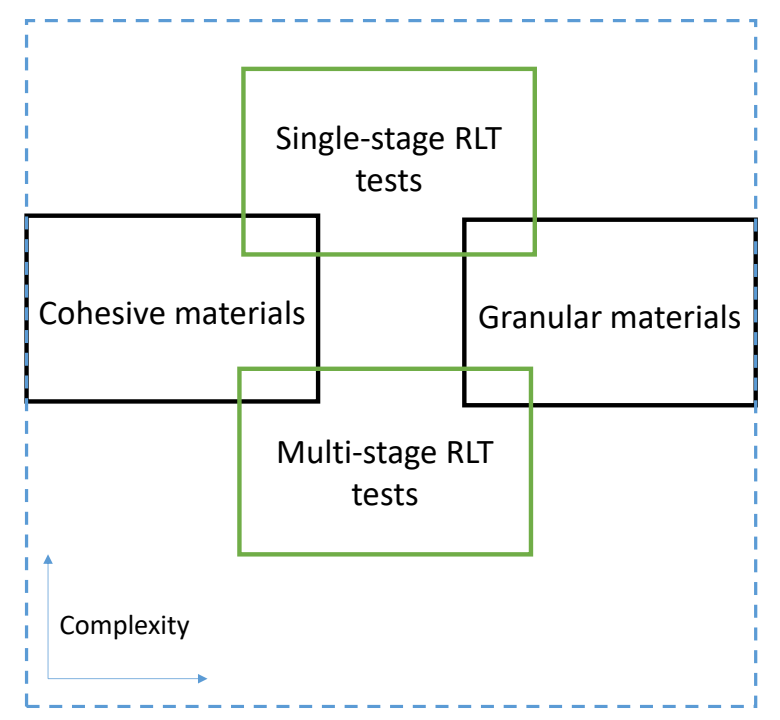

Figure 5. Division of the mechanistic-empirical permanent deformation models 


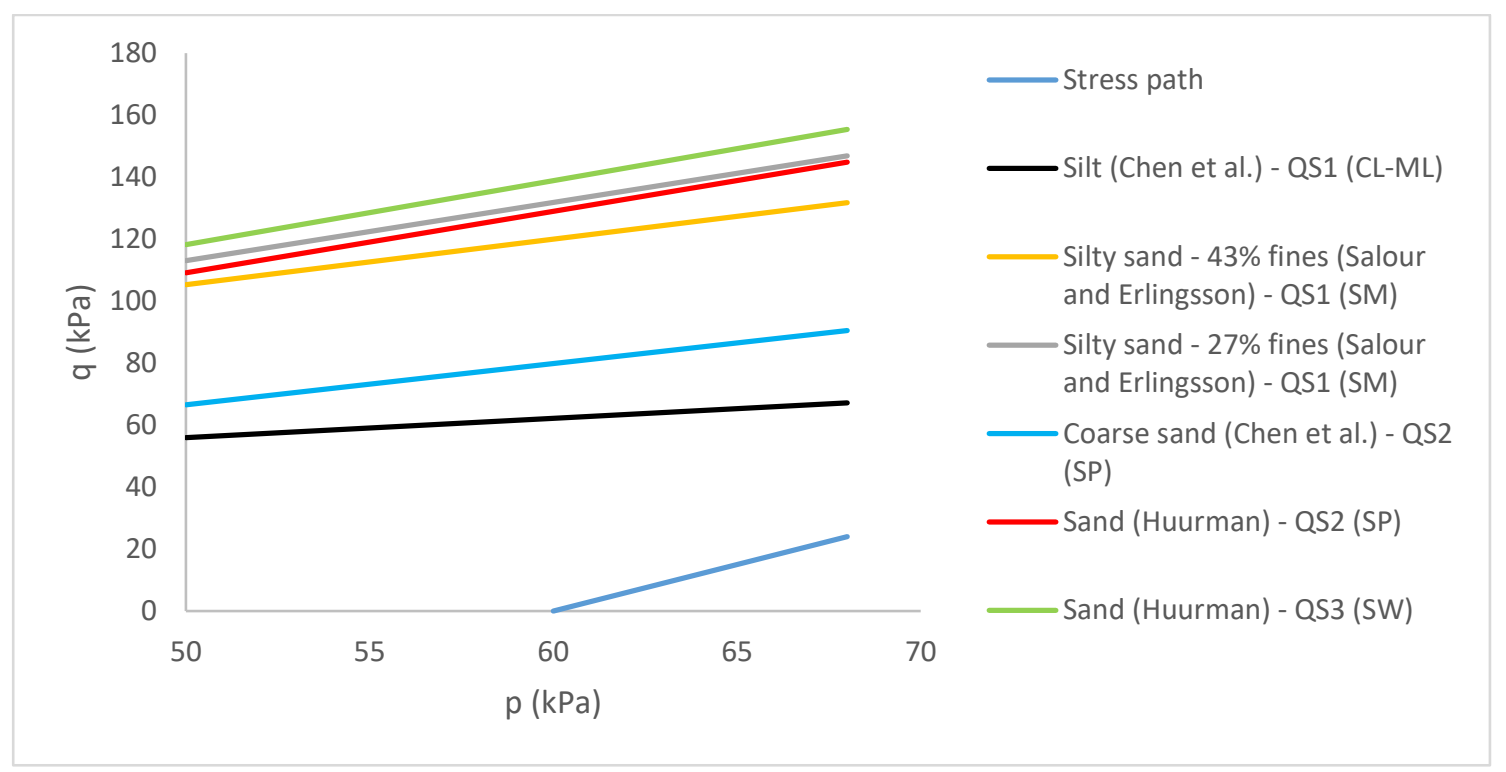

Figure 6. Total stress path selected and failure envelopes of Mohr-Coulomb yielding criteria 


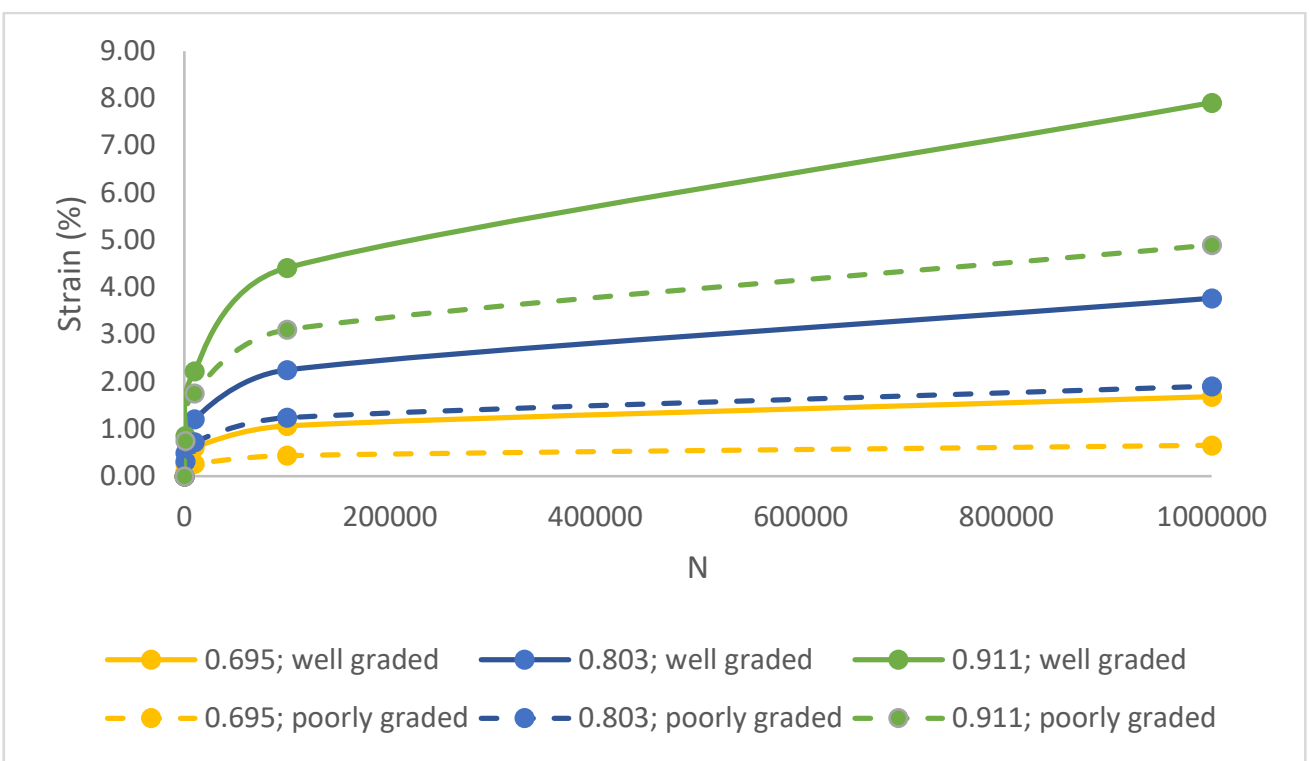

Figure 7. Comparison between the permanent deformation of a poorly graded (C. Bruynweg) and well-graded (crusher) sand under different stress ratios 


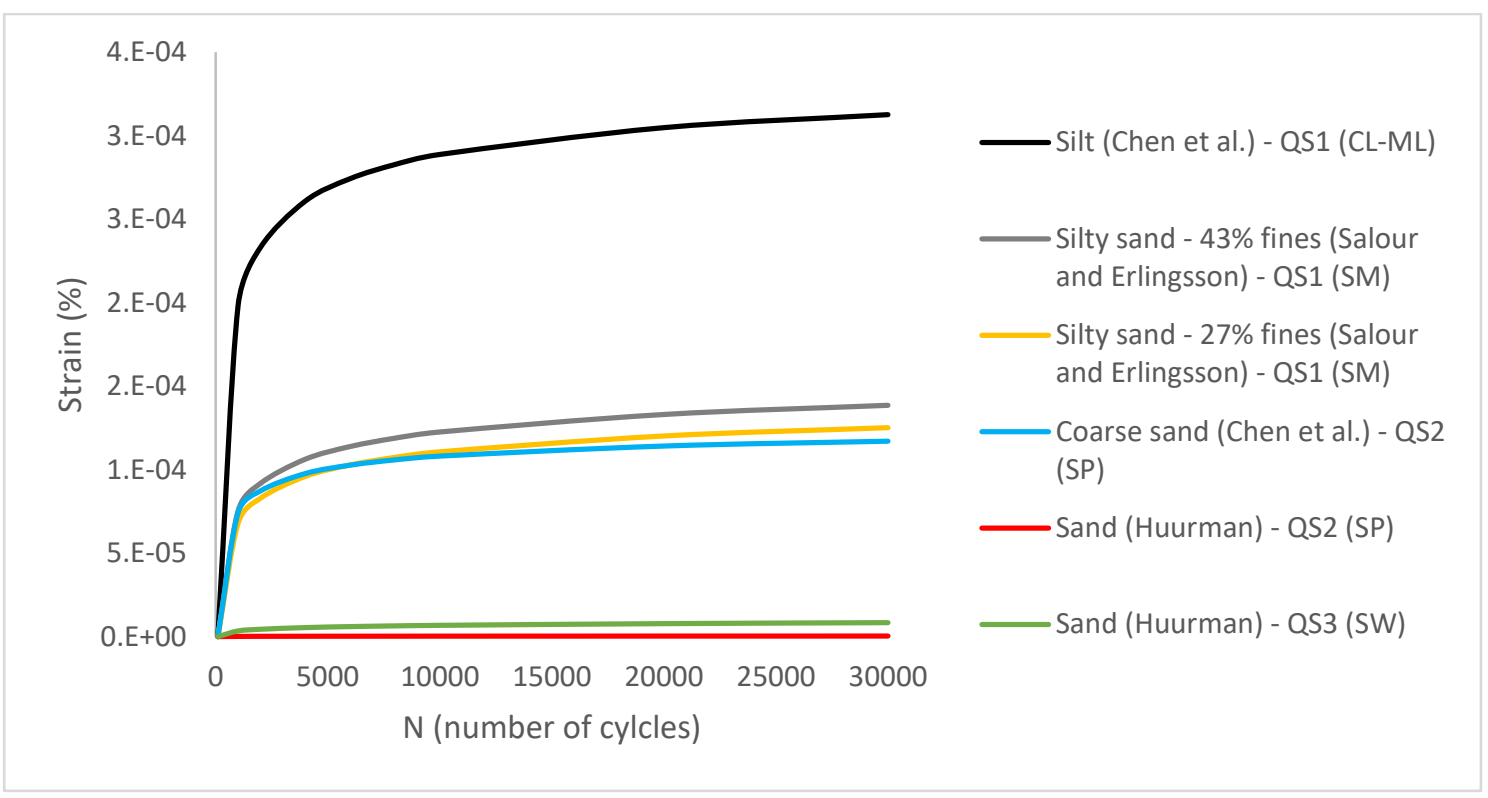

Figure 8. Permanent deformation of the materials applying the Chen et al. (2014) model 


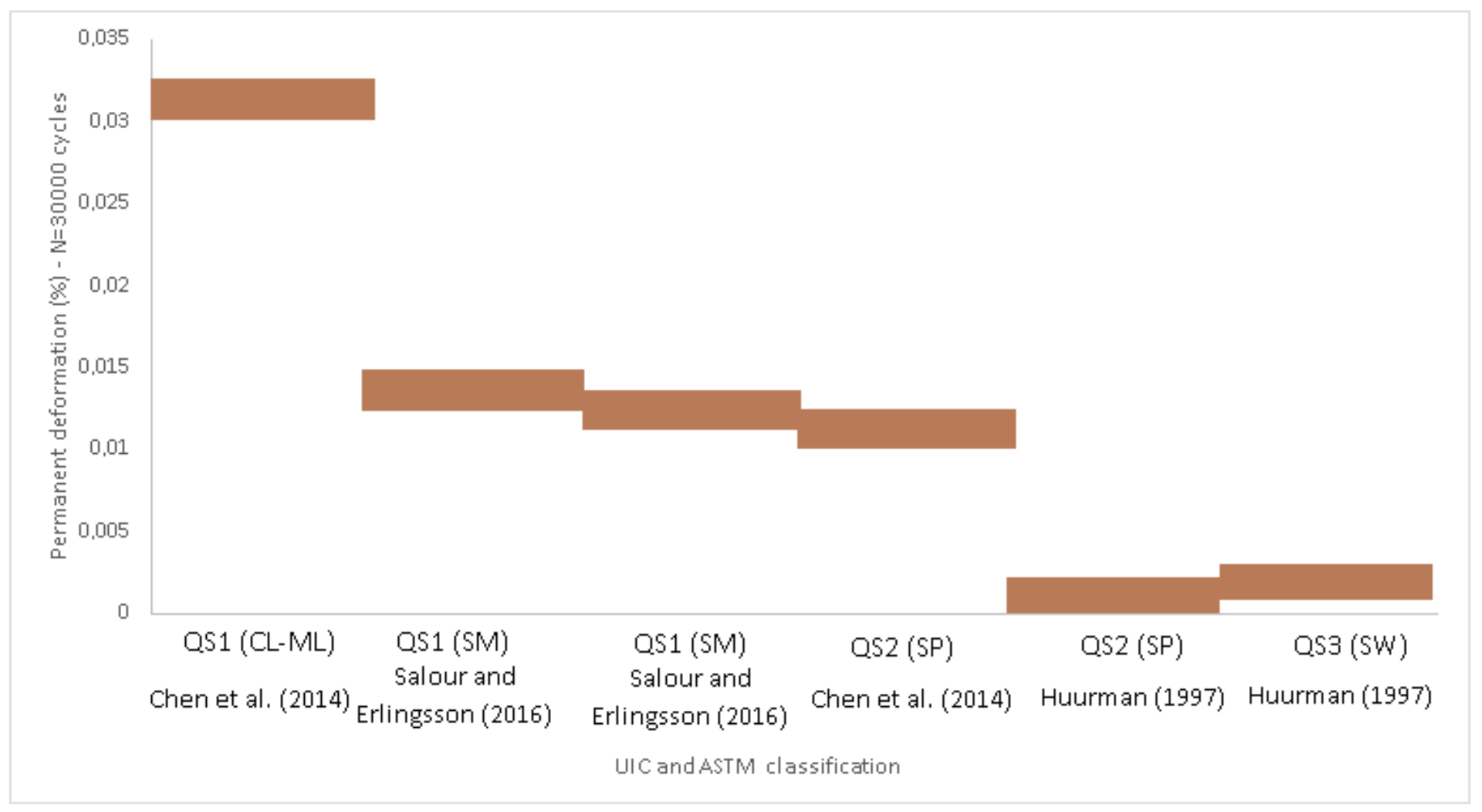

Figure 9. Permanent deformation predicted by Chen et al. (2014)'s model for different soils $(\mathrm{N}=30,000$ cycles $)$ under a stress ratio $\sigma_{1} / \sigma_{1: \mathrm{f}}=0.4$ 

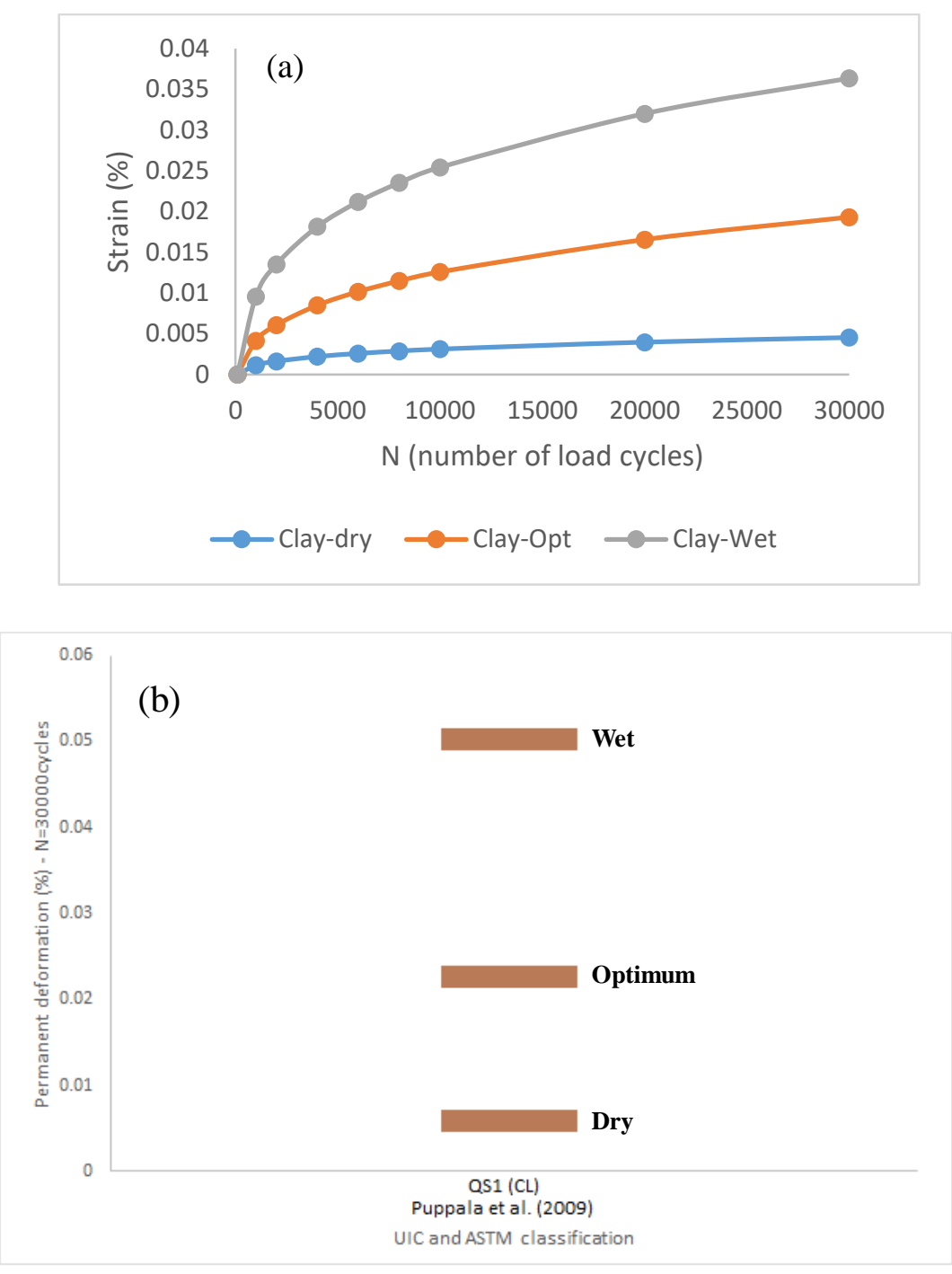

Figure 10. Influence of the moisture content in the permanent deformation of a clay (Puppala's model): a) permanent deformation results applying the Chen et al. (2014) model; b) Ranking of permanent deformation for clay 